Josephsohn, et. al; Page S1

\title{
Ag-CATALYZED ASYMMETRIC MANNICH REACTIONS OF ENOL ETHERS AND ARYL, ALKYL, ALKENYL AND ALKYNYL IMINES
}

\author{
Nathan S. Josephsohn, Marc L. Snapper* and Amir H. Hoveyda* \\ Department of Chemistry, Merkert Chemistry Center, Boston College \\ Chestnut Hill, Massachusetts 02467
}

\section{SUPPORTING INFORMATION}

General. Infrared (IR) spectra were recorded on a Perkin Elmer 781 spectrophotometer, $v_{\max }$ in $\mathrm{cm}^{-1}$. Bands are characterized as broad (br), strong (s), medium (m), or weak (w). ${ }^{1} \mathrm{H}$ NMR spectra were recorded on a Varian Unity INOVA $400(400 \mathrm{MHz})$ spectrometer. Chemical shifts are reported in ppm from tetramethylsilane with the solvent resonance resulting from incomplete deuteration as the internal standard $\left(\mathrm{CDCl}_{3}: 7.26\right)$. Data are reported as follows: chemical shift, integration, multiplicity $(\mathrm{s}=$ singlet, $\mathrm{d}=$ doublet, $\mathrm{t}=$ triplet, $\mathrm{q}=$ quartet, $\mathrm{br}=$ broad, $\mathrm{m}=$ multiplet $)$, and coupling constants in Hz. ${ }^{13} \mathrm{C}$ NMR spectra were recorded on a Varian Unity INOVA $400(100 \mathrm{MHz})$ with complete proton decoupling. Chemical shifts are reported in $\mathrm{ppm}$ from tetramethylsilane with the solvent resonance as the internal standard $\left(\mathrm{CDCl}_{3}\right.$ : 77.16). Enantiomeric ratios were determined by high-performance liquid chromatography (HPLC) by a Shimadzu chromatograph and chiralpak AD, OD and OJ columns $(4.6 \mathrm{~mm}$ x $250 \mathrm{~mm}$ chiral column by Chiral Technologies) in comparison with authentic racemic materials. Elemental analyses were preformed by Robertson Microlit Laboratories (Madison, New Jersey). All high-resolution mass spectrometry was preformed at Boston College on a Micromass LCT ESI-MS (positive mode). Optical rotation values were recorded on a Rudolph Research Analytical Autopol IV polarimeter.

Unless otherwise stated, all reactions conducted under open atmosphere in $16 \times 150$ $\mathrm{mm}$ borosilicate test tubes. All liquid reagents were handled with a Fisherbrand Finnpipette repeating pipetter. J.T. Baker reagent grade THF was used without purification. Fisherbrand HPLC grade 2-Propanol was used without purification. Unless otherwise stated silver acetate (99\%), iodobenzene diacetate, DIBAL-H, LAH, $\mathrm{NaCNBH}_{3}$, formaldehyde ( $30 \% \mathrm{v} / \mathrm{v}$ in $\mathrm{H}_{2} \mathrm{O}$ ), $\mathrm{Boc}_{2} \mathrm{O}, p$-anisidine, $o$-anisidine 1-phenyl-1(trimethylsilyloxy)ethylene (3a) and all commercially available aldehydes (for imines) were purchased from Aldrich and used without further purification.

$o$-Anisidyl imines, ${ }^{1}$ 5-oxo-pentanoic acid methyl ester, ${ }^{2}$ trimethyl[(1methylethenyl)oxy]-silane ${ }^{3}(\mathbf{3 b})$ and ligand $\mathbf{1}^{4}$ were prepared according to literature procedure.

\footnotetext{
${ }^{1}$ a) Saito, S; Hatanaka, K.; Yamamoto, H. Org. Lett. 2000, 2, 1891-1894. (b) Adrian, Jr. J. C.; Barkin, J. L.; Hassib, L. Tetrahedron Lett. 1999, 40, 2457-2460.

${ }^{2}$ Mioskowski, P. C. C.; Falk, J. R. Tetrahedron Lett. 1989, 30, 2545-2548.

${ }^{3}$ Walshe, N. D. A.; Goodwin, G. B. T.; Smith, G. C.; Woodward, F. E. Org. Synth. 1986, 65, 1-5.

${ }^{4}$ Josephsohn, N. J.; Snapper, M. L.; Hoveyda, A. H. J. Am. Chem. Soc. 2003, 125, 1418-1419.
} 


\section{Representative procedure for the Ag-catalyzed asymmetric Mannich reaction:} Ligand $1(18 \mathrm{mg}, 36 \mu \mathrm{mol})$ and $\mathrm{AgOAc}(6.0 \mathrm{mg}, 36 \mu \mathrm{mol})$ were weighed into a $16 \mathrm{x} 150$ $\mathrm{mm}$ test tube. The contents were dissolved in $1 \mathrm{~mL}$ of THF and allowed to stir for $5 \mathrm{~min}$ at $22{ }^{\circ} \mathrm{C}$. Imine $2 \mathbf{d}(310 \mathrm{mg}, 1.20 \mathrm{mmol})$ was added immediately followed by $100 \mu \mathrm{L} i$ $\mathrm{PrOH}(1.3 \mathrm{mmol})$. The test tube was capped with a septum, and allowed to stir in a cold room at $4{ }^{\circ} \mathrm{C}$ for $5 \mathrm{~min}$. Enol ether $3 \mathbf{a}(0.5 \mathrm{~mL}, 2.4 \mathrm{mmol})$ was added and the reaction mixture was allowed to stir at $4{ }^{\circ} \mathrm{C}$ for $16 \mathrm{~h}$. The reaction was quenched upon addition of $2 \mathrm{~mL}$ of $10 \%$ aqueous $\mathrm{HCl}$ followed by vigorous stirring for $5 \mathrm{~min} . \mathrm{CH}_{2} \mathrm{Cl}_{2}(5 \mathrm{~mL})$ was added and the mixture was allowed to stir vigorously for $1 \mathrm{~min}$. The layers were allowed to separate, and the bottom layer $\left(\mathrm{CH}_{2} \mathrm{Cl}_{2}\right)$ was removed with a pipette and placed into a round-bottom flask. The aqueous layer was washed with $2 \times 5 \mathrm{~mL}$ portions of $\mathrm{CH}_{2} \mathrm{Cl}_{2}$ and separated as stated above. The combined organic layers were concentrated (without drying) and purified by silica gel chromatography (4:1 hexanes: $\mathrm{Et}_{2} \mathrm{O}$ in most cases $4: 1$ hexanes: EtOAc when enol ether 3b is used), to deliver $396 \mathrm{mg}$ (1.05 mmol, 88\% yield) of the desired product $\mathbf{4 d}$ as a yellow-orange solid.

(-)-3-(2-Methoxyphenylamino)-1,3-diphenylpropan-1-one (4aa); A modified procedure was used. Ligand $1(6.0 \mathrm{mg}, 12 \mu \mathrm{mol})$ and AgOAc (2.0

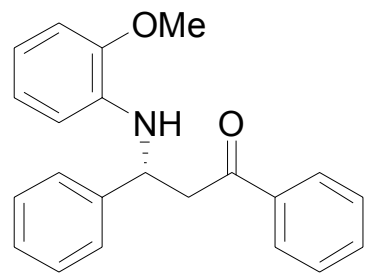
$\mathrm{mg}, 12 \mu \mathrm{mol})$ were weighed into a $16 \times 150 \mathrm{~mm}$ test tube. The contents were dissolved in $0.2 \mathrm{~mL}$ of THF and allowed to stir for $5 \mathrm{~min}$ at $22{ }^{\circ} \mathrm{C}$. Imine $\mathbf{2 a}(85 \mathrm{mg}, 0.4 \mathrm{mmol})$ was added immediately followed by $33 \mu \mathrm{L} i$-PrOH $(0.45 \mathrm{mmol})$. The test tube was capped with a septum, and allowed to stir in a cold bath at $-10^{\circ} \mathrm{C}$ for $5 \mathrm{~min}$. Enol ether $\mathbf{3 a}(160 \mu \mathrm{L}, 0.8 \mathrm{mmol})$ was added and the reaction was allowed to stir at $-10{ }^{\circ} \mathrm{C}$ for $16 \mathrm{~h}$. The reaction was quenched upon addition of $2 \mathrm{~mL}$ of $10 \%$ aqueous $\mathrm{HCl}$ followed by vigorous stirring for $5 \mathrm{~min} . \mathrm{CH}_{2} \mathrm{Cl}_{2}$ $(5 \mathrm{~mL})$ was added and the mixture was allowed to stir vigorously for $1 \mathrm{~min}$. The layers were allowed to separate, and the bottom layer $\left(\mathrm{CH}_{2} \mathrm{Cl}_{2}\right)$ was removed with a pipette and placed into a round-bottom flask. The aqueous layer was washed with 2 x $5 \mathrm{~mL}$ portions of $\mathrm{CH}_{2} \mathrm{Cl}_{2}$ and separated as stated above. The combined organic layers were concentrated (without drying) and purified by silica gel chromatography (4:1 hexanes: $\left.\mathrm{Et}_{2} \mathrm{O}\right)$ to deliver $72 \mathrm{mg}(0.22 \mathrm{mmol}, 54 \%)$ of the desired product $4 \mathbf{a a}$ as a yellow solid. IR (neat, $\mathrm{NaCl}$ ): 3410 (w), 3063 (w), 1686 (s), 1599 (s), 1512 (s), 1456 (s), 1357 (m), 1258 (m), 1227 (s), $1128(\mathrm{~m}), 1028(\mathrm{~m}), 732(\mathrm{~s}), 700(\mathrm{~s}) .{ }^{1} \mathrm{H} \mathrm{NMR}\left(\mathrm{CDCl}_{3}, 400 \mathrm{MHz}\right): \delta$ 7.92-7.90 (2H, d, $J$ $=7.32 \mathrm{~Hz}), 7.56-7.20(8 \mathrm{H}, \mathrm{m}), 6.76-6.60(3 \mathrm{H}, \mathrm{m}), 6.45(1 \mathrm{H}, \mathrm{dd}, J=7.7,1.5 \mathrm{~Hz}), 5.06$ $(1 \mathrm{H}$, apparent triplet, $J=6.4 \mathrm{~Hz}), 5.00(1 \mathrm{H}, \mathrm{br}), 3.84(3 \mathrm{H}, \mathrm{s}), 3.50(2 \mathrm{H}$, apparent doublet, $J=5.9 \mathrm{~Hz}) .{ }^{13} \mathrm{C} \mathrm{NMR}\left(\mathrm{CDCl}_{3}, 100 \mathrm{MHz}\right): \delta 198.0,147.2,146.4,143.3,137.0,133.4$, $128.9,128.8,128.3,127.4,126.6,121.2,117.0,111.5,109.6,55.7,54.5,46.8$. HRMS (ES) Calcd for $\mathrm{C}_{22} \mathrm{H}_{21} \mathrm{NO}_{2} \mathrm{Na}$ : 354.1465; Found: 354.1470. $[\alpha]_{\mathrm{D}}{ }^{20}=-36.2^{\circ}(c=0.347$, $\mathrm{CHCl}_{3}$ ) for a $94 \%$ ee sample.

The optical purity of 4aa was established by chiral HPLC analysis (OD column, 9/1 hexanes/ $i$-PrOH eluent, $1 \mathrm{~mL} / \mathrm{min}$ and a lamp setting of $254 \mathrm{~nm}$ ); chromatograms are shown below. 

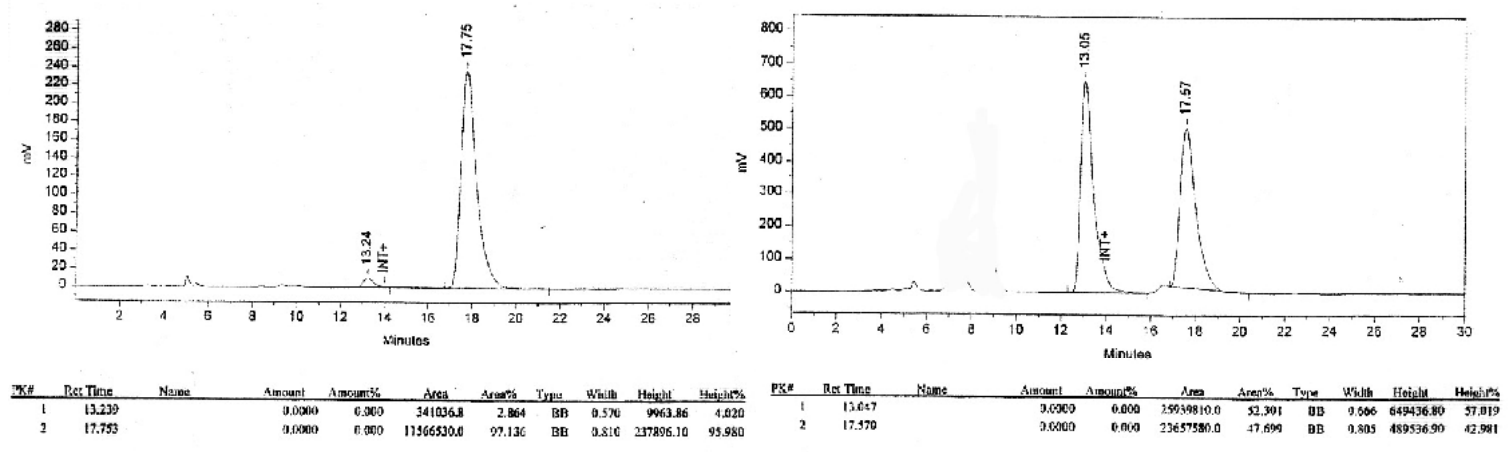

(-)-4-(2-Methoxyphenylamino)-4-phenylbutan-2-one (4ab); A modified procedure OMe was used. Ligand 1 (6.0 mg, $12 \mu \mathrm{mol})$ and AgOAc $(2.0 \mathrm{mg}, 12 \mu \mathrm{mol})$ were weighed into a $16 \times 150 \mathrm{~mm}$ test tube. The contents were $\mathrm{NH} O$ dissolved in $0.2 \mathrm{~mL}$ of THF and allowed to stir for $5 \mathrm{~min}$ at $22{ }^{\circ} \mathrm{C}$. Imine $2 \mathbf{a}(85 \mathrm{mg}, 0.4 \mathrm{mmol})$ was added immediately followed by $33 \mu \mathrm{L}$ $i$-PrOH $(0.45 \mathrm{mmol})$. The test tube was capped with a septum, and allowed to stir in a cold bath at $-10^{\circ} \mathrm{C}$ for $5 \mathrm{~min}$. Enol ether $3 \mathbf{b}(130 \mu \mathrm{L}$, $0.80 \mathrm{mmol}$ ) was added and the reaction was allowed to stir at $-10{ }^{\circ} \mathrm{C}$ for $16 \mathrm{~h}$. The reaction was quenched upon addition of $2 \mathrm{~mL}$ of $10 \%$ aqueous $\mathrm{HCl}$ followed by vigorous stirring for $5 \mathrm{~min}$. $\mathrm{CH}_{2} \mathrm{Cl}_{2}(5 \mathrm{~mL})$ was added and the mixture was allowed to stir vigorously for $1 \mathrm{~min}$. The layers were allowed to separate, and the bottom layer $\left(\mathrm{CH}_{2} \mathrm{Cl}_{2}\right)$ was removed with a pipette and placed into a round-bottom flask. The aqueous layer was washed with $2 \times 5 \mathrm{~mL}$ portions of $\mathrm{CH}_{2} \mathrm{Cl}_{2}$ and separated as stated above. The combined organic layers were concentrated (without drying) and purified by silica gel chromatography (4:1 hexanes:EtOAc) to deliver $70 \mathrm{mg}(0.26 \mathrm{mmol}, 65 \%)$ of the desired product $4 \mathbf{a b}$ as a clear colorless oil. IR (neat, $\mathrm{NaCl}$ ): $3413(\mathrm{w}), 2926(\mathrm{w}), 1715(\mathrm{~s}), 1602$ (m), 1515 (s), $1453(\mathrm{~m}), 1359$ (m), 1228 (s), 1028 (m), $741(\mathrm{~m}), 697$ (m). ${ }^{1} \mathrm{H}$ NMR $\left(\mathrm{CDCl}_{3}, 400 \mathrm{MHz}\right): \delta 7.36-7.19(5 \mathrm{H}, \mathrm{m}), 6.75-6.60(3 \mathrm{H}, \mathrm{m}), 6.42(1 \mathrm{H}, \mathrm{dd}, J=7.7,1.3$ $\mathrm{Hz}), 4.92-4.85(2 \mathrm{H}, \mathrm{m}), 3.85(3 \mathrm{H}, \mathrm{s}), 2.95(2 \mathrm{H}, \mathrm{ddd}, J=16.1,7.5,5.9 \mathrm{~Hz}), 2.10(3 \mathrm{H}, \mathrm{s})$.

${ }^{13} \mathrm{C} \mathrm{NMR}\left(\mathrm{CDCl}_{3}, 100 \mathrm{MHz}\right): \delta 207.1,147.3,143.0,136.9,128.1,127.7,126.7,121.5$, 117.4, 111.7, 109.8, 55.8, 54.5, 52.1, 31.0. HRMS (ES) Calcd for $\mathrm{C}_{17} \mathrm{H}_{19} \mathrm{NO}_{2} \mathrm{Na}$ : 292.1320; Found: 292.1313. $[\alpha]_{\mathrm{D}}{ }^{20}=-38.2^{\circ}\left(c=0.427, \mathrm{CHCl}_{3}\right)$ for a $92 \%$ ee sample.

The optical purity of $\mathbf{4 a b}$ was established by chiral HPLC analysis (OD column, 9/1 hexanes/ $i$ - $\mathrm{PrOH}$ eluent, $1 \mathrm{~mL} / \mathrm{min}$ and a lamp setting of $254 \mathrm{~nm}$ ); chromatograms are shown below.
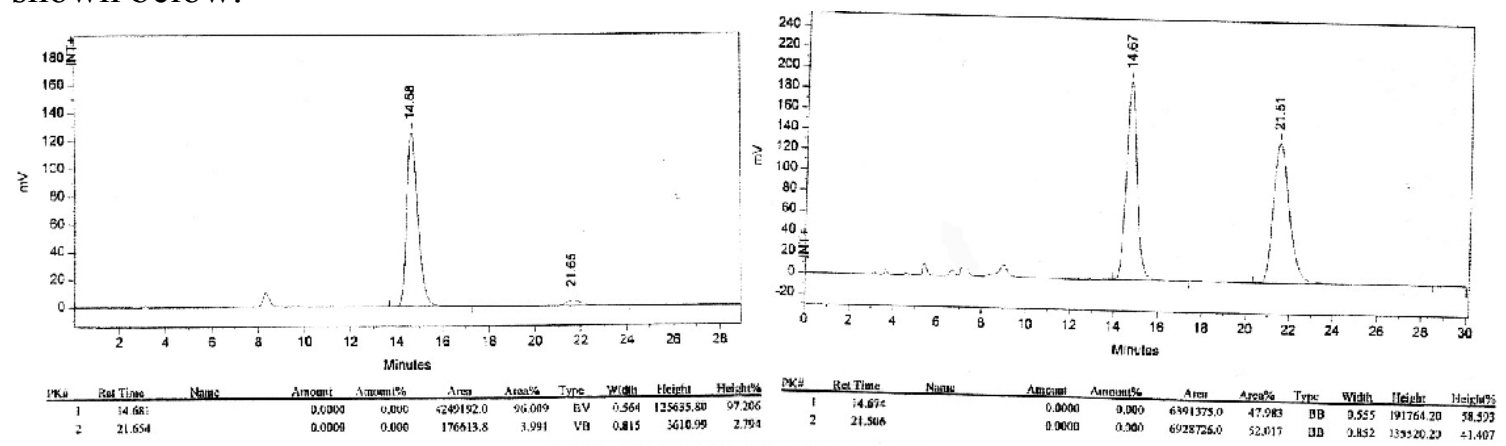
(-)-3-(4-Methoxyphenyl)-3-(2-methoxyphenylamino)-1-phenylpropan-1-one (4ba); A modified procedure was used. Ligand 1 (18 mg, $36 \mu \mathrm{mol})$ and AgOAc (6.0 mg, 36

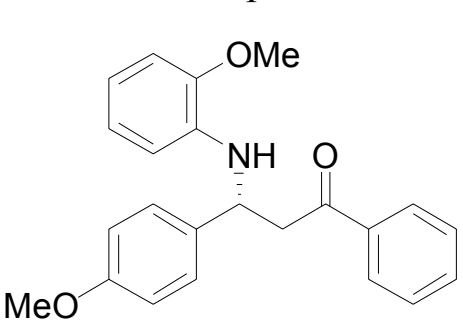
$\mu \mathrm{mol})$ were weighed into a $16 \times 150 \mathrm{~mm}$ test tube. The contents were dissolved in $1 \mathrm{~mL}$ of toluene and allowed to stir for $5 \mathrm{~min}$ at $22^{\circ} \mathrm{C}$. Imine $\mathbf{2 b}(320 \mathrm{mg}, 1.20 \mathrm{mmol})$ was added immediately followed by $100 \mu \mathrm{L} i$-PrOH $(1.30 \mathrm{mmol})$. The test tube was capped with a septum, and allowed to stir in a cold bath at $23{ }^{\circ} \mathrm{C}$ for $5 \mathrm{~min}$. Enol ether 3a $(0.5 \mathrm{~mL}, 2.4$ mmol) was added and the reaction was allowed to stir at $23{ }^{\circ} \mathrm{C}$

for $16 \mathrm{~h}$. The reaction was quenched upon addition of $2 \mathrm{~mL}$ of $10 \%$ aqueous $\mathrm{HCl}$ followed by vigorous stirring for $5 \mathrm{~min}$. $\mathrm{CH}_{2} \mathrm{Cl}_{2}(5 \mathrm{~mL})$ was added and the mixture was allowed to stir vigorously for $1 \mathrm{~min}$. The layers were allowed to separate, and the bottom layer $\left(\mathrm{CH}_{2} \mathrm{Cl}_{2}\right)$ was removed with a pipette and placed into a round-bottom flask. The aqueous layer was washed with $2 \times 5 \mathrm{~mL}$ portions of $\mathrm{CH}_{2} \mathrm{Cl}_{2}$ and separated as stated above. The combined organic layers were concentrated (without drying) and purified by silica gel chromatography $\left(4: 1\right.$ hexanes: $\left.\mathrm{Et}_{2} \mathrm{O}\right)$ to deliver $88 \mathrm{mg}(0.24 \mathrm{mmol}, 61 \%)$ of the desired product $4 \mathbf{b a}$ as a white solid. IR (neat, $\mathrm{NaCl}): 1681(\mathrm{~m}), 1600(\mathrm{~m}), 1513(\mathrm{~s}), 1457$ (m), 1246 (m), $1227(\mathrm{~m}), 1028(\mathrm{~m}), 736(\mathrm{~m}) .{ }^{1} \mathrm{H} \mathrm{NMR}\left(\mathrm{CDCl}_{3}, 400 \mathrm{MHz}\right): \delta 7.92(2 \mathrm{H}$, $\mathrm{dd}, J=8.3,0.7 \mathrm{~Hz}), 7.58-7.36(5 \mathrm{H}, \mathrm{m}), 6.87-6.48(6 \mathrm{H}, \mathrm{m}), 5.04$ (1H, apparent doublet, $J$ $=6.4 \mathrm{~Hz}), 4.97(1 \mathrm{H}, \mathrm{br}), 3.86(3 \mathrm{H}, \mathrm{s}), 3.77(3 \mathrm{H}, \mathrm{s}), 3.51(2 \mathrm{H}$, apparent doublet, $J=6.4$ $\mathrm{Hz}) .{ }^{13} \mathrm{C} \mathrm{NMR}\left(\mathrm{CDCl}_{3}, 100 \mathrm{MHz}\right): \delta 198.2,158.9,147.2,137.0,136.9,135.2,133.6$, 128.7, 128.3, 127.7, 121.2, 117.0, 114.3, 111.5, 109.6, 55.6, 55.3, 53.9, 46.8. HRMS (ES) Calcd. for $\mathrm{C}_{23} \mathrm{H}_{20} \mathrm{NO}_{3} \mathrm{Na}$ : 384.1582; Found: 384.1576. Anal Calcd. for $\mathrm{C}_{18} \mathrm{H}_{17} \mathrm{NO}_{2}$ : C, 76.43, H, 6.41; Found: C, 77.36, H, 6.48. $[\alpha]_{\mathrm{D}}{ }^{20}=-33.5^{\circ}\left(c=0.967, \mathrm{CHCl}_{3}\right)$ for a $96 \%$ ee sample.

The optical purity of $\mathbf{4 b a}$ was established by chiral HPLC analysis (OD column, 9/1 hexanes/ $i$-PrOH eluent, $1 \mathrm{~mL} / \mathrm{min}$ and a lamp setting of $254 \mathrm{~nm}$ ); chromatograms are shown below.
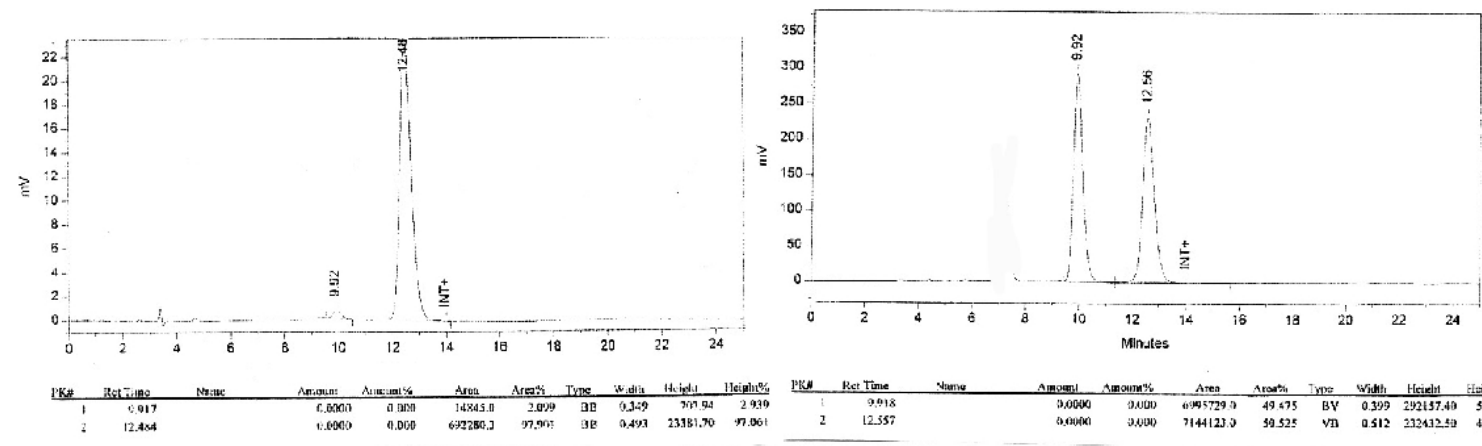

(-)-4-(4-Methoxyphenyl)-4-(2-methoxyphenylamino)-butan-2-one (4bb); A modified

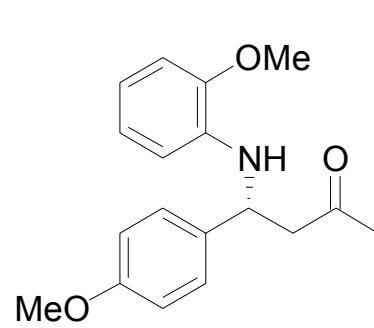

procedure was used. Ligand $1(10 \mathrm{mg}, 20 \mu \mathrm{mol})$ and AgOAc (3.0 $\mathrm{mg}, 20 \mu \mathrm{mol})$ were weighed into a $16 \times 150 \mathrm{~mm}$ test tube. The contents were dissolved in $0.4 \mathrm{~mL}$ of toluene and allowed to stir for $5 \mathrm{~min}$ at $22{ }^{\circ} \mathrm{C}$. Imine $\mathbf{2 b}(100 \mathrm{mg}, 0.40 \mathrm{mmol})$ was added 
immediately followed by $33 \mu \mathrm{L} i$-PrOH $(0.45 \mathrm{mmol})$. The test tube was capped with a septum, and allowed to stir in a cold room at $4{ }^{\circ} \mathrm{C}$ for $5 \mathrm{~min}$. Enol ether $\mathbf{3 b}(130 \mu \mathrm{L}, 0.80$ mmol) was added and the reaction was allowed to stir at $4{ }^{\circ} \mathrm{C}$ for $18 \mathrm{~h}$. The reaction was quenched upon addition of $2 \mathrm{~mL}$ of $10 \%$ aqueous $\mathrm{HCl}$ followed by vigorous stirring for 5 min. $\mathrm{CH}_{2} \mathrm{Cl}_{2}(5 \mathrm{~mL})$ was added and the mixture was allowed to stir vigorously for 1 $\mathrm{min}$. The layers were allowed to separate, and the bottom layer $\left(\mathrm{CH}_{2} \mathrm{Cl}_{2}\right)$ was removed with a pipette and placed into a round-bottom flask. The aqueous layer was washed with $2 \times 5 \mathrm{~mL}$ portions of $\mathrm{CH}_{2} \mathrm{Cl}_{2}$ and separated as stated above. The combined organic layers were concentrated (without drying) and purified by silica gel chromatography (4:1 hexanes:EtOAc) to deliver $85 \mathrm{mg}(0.29 \mathrm{mmol}, 71 \%)$ of the desired product $\mathbf{4 b b}$ as a light yellow oil. IR (neat, $\mathrm{NaCl}$ ): $1712(\mathrm{~m}), 1606(\mathrm{~m}), 1507(\mathrm{~s}), 1457(\mathrm{~m}), 1240(\mathrm{~s}), 1227(\mathrm{~m})$, $1184(\mathrm{~m}), 1184(\mathrm{~m}), 1028(\mathrm{~m}), 730(\mathrm{~m}) .{ }^{1} \mathrm{H}$ NMR $\left(\mathrm{CDCl}_{3}, 400 \mathrm{MHz}\right): \delta 7.28(2 \mathrm{H}, \mathrm{d}, J=$ $8.6 \mathrm{~Hz}), 6.85(2 \mathrm{H}, \mathrm{dd}, J=8.1,0.7 \mathrm{~Hz}), 6.77-6.61(3 \mathrm{H}, \mathrm{m}), 6.45(1 \mathrm{H}, \mathrm{d}, J=7.9 \mathrm{~Hz}), 4.84$, $(1 \mathrm{H}$, apparent doublet, $J=6.8 \mathrm{~Hz}), 4.79(1 \mathrm{H}, \mathrm{br}), 3.86(3 \mathrm{H}, \mathrm{s}), 3.77(3 \mathrm{H}, \mathrm{s}), 2.94(2 \mathrm{H}$, ddd, $J=15.7,7.1,6.2 \mathrm{~Hz}), 2.10(3 \mathrm{H}, \mathrm{s}) .{ }^{13} \mathrm{C} \mathrm{NMR}\left(\mathrm{CDCl}_{3}, 100 \mathrm{MHz}\right): \delta 207.0,158.9$, 147.1, 136.8, 134.8, 127.5, 121.2, 117.0, 114.2, 111.4, 109.6, 55.6, 55.3, 53.6, 51.8, 30.8. HRMS (ES) Calcd for $\mathrm{C}_{18} \mathrm{H}_{21} \mathrm{NO}_{3} \mathrm{Na}$ : 322.1418; Found: 322.1419 . [ $[\alpha]_{\mathrm{D}}{ }^{20}=-17.3^{\circ}(c=$ $2.35, \mathrm{CHCl}_{3}$ ) for a $90 \%$ ee sample.

The optical purity of $\mathbf{4 b b}$ was established by chiral HPLC analysis (OD column, 9/1 hexanes/ $i-\mathrm{PrOH}$ eluent, $1 \mathrm{~mL} / \mathrm{min}$ and a lamp setting of $254 \mathrm{~nm}$ ); chromatograms are shown below.
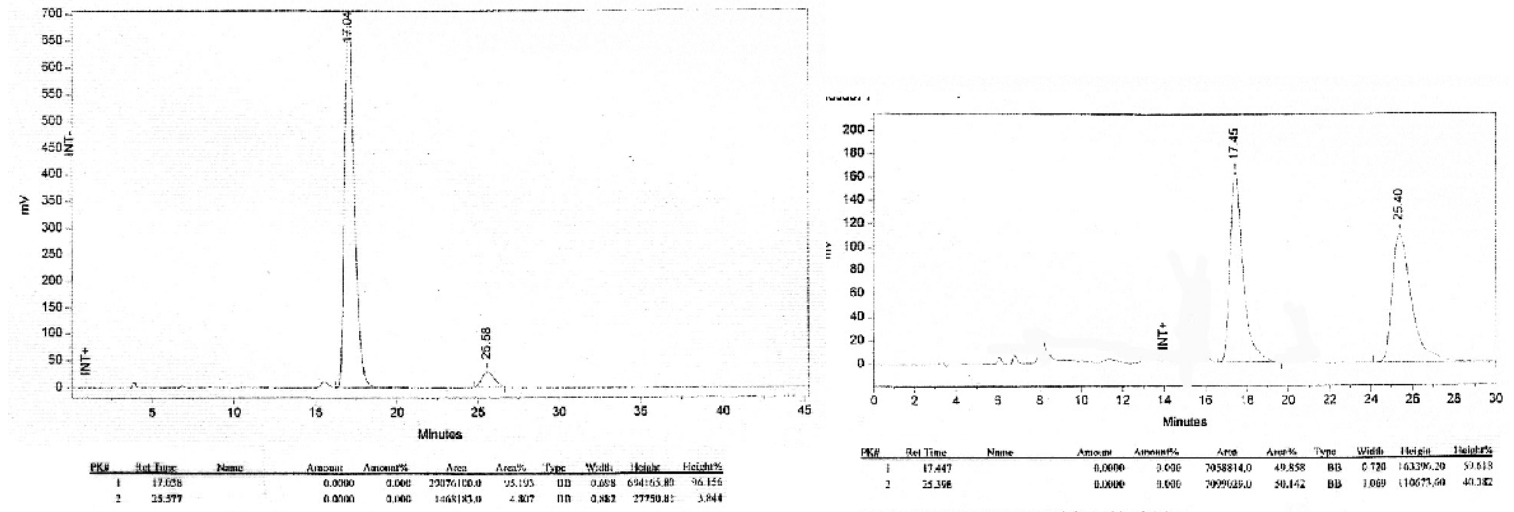

(-)-3-(2-Methoxyphenylamino)-3-(4-nitrophenyl)-1-phenylpropan-1-one (4ca); A

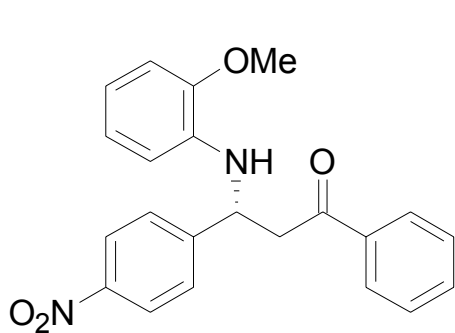
modified procedure was used. Ligand 1 (18 $\mathrm{mg}, 36 \mu \mathrm{mol})$ and $\mathrm{AgOAc}(6.0 \mathrm{mg}, 36 \mu \mathrm{mol})$ were weighed into a $16 \times 150$ $\mathrm{mm}$ test tube. The contents were dissolved in $1 \mathrm{~mL}$ of THF and allowed to stir for $5 \mathrm{~min}$ at $22^{\circ} \mathrm{C}$. Imine $2 \mathrm{c}(310 \mathrm{mg}$, $1.20 \mathrm{mmol})$ was added immediately followed by $100 \mu \mathrm{L} i$ PrOH $(1.30 \mathrm{mmol})$. The test tube was capped with a septum, and allowed to stir in a cold bath at $-5{ }^{\circ} \mathrm{C}$ for 5 min. Enol ether 3a $(0.5 \mathrm{~mL}, 2.4 \mathrm{mmol})$ was added and the reaction was allowed to stir at $-5{ }^{\circ} \mathrm{C}$ for $16 \mathrm{~h}$. The reaction was quenched upon addition of $2 \mathrm{~mL}$ of $10 \%$ aqueous $\mathrm{HCl}$ followed by vigorous stirring for $5 \mathrm{~min}$. $\mathrm{CH}_{2} \mathrm{Cl}_{2}(5 \mathrm{~mL})$ was added and the mixture was allowed to stir vigorously for $1 \mathrm{~min}$. The layers were allowed to separate, and the bottom layer $\left(\mathrm{CH}_{2} \mathrm{Cl}_{2}\right)$ was removed with a pipette and placed into a round-bottom flask. The aqueous layer was washed with $2 \times 5 \mathrm{~mL}$ portions of $\mathrm{CH}_{2} \mathrm{Cl}_{2}$ and separated as stated above. The 
combined organic layers were concentrated (without drying) and purified by silica gel chromatography (4:1 hexanes: $\left.\mathrm{Et}_{2} \mathrm{O}\right)$ to deliver $396 \mathrm{mg}(1.1 \mathrm{mmol}, 88 \%)$ of the desired product 4ca as a orange solid. IR (neat, $\mathrm{NaCl}): 1684(\mathrm{~m}), 1596(\mathrm{~m}), 1515(\mathrm{~s}), 1453(\mathrm{~m})$, $1340(\mathrm{~s}), 1228(\mathrm{~m}), 741(\mathrm{~m}) .{ }^{1} \mathrm{H}$ NMR $\left(\mathrm{CDCl}_{3}, 400 \mathrm{MHz}\right): \delta 8.16(2 \mathrm{H}, \mathrm{d}, J=8.6 \mathrm{~Hz})$, $7.92(2 \mathrm{H}, \mathrm{dd}, J=7.1,1.8 \mathrm{~Hz}), 7.65-7.44(5 \mathrm{H}, \mathrm{m}), 6.80-6.65(3 \mathrm{H}, \mathrm{m}), 6.35(1 \mathrm{H}, \mathrm{dd}, J=$ 7.3, $1.8 \mathrm{~Hz}), 5.18(1 \mathrm{H}$, apparent doublet, $J=6.2 \mathrm{~Hz}), 5.13(1 \mathrm{H}, \mathrm{s}), 3.87(3 \mathrm{H}, \mathrm{s}), 3.57(2 \mathrm{H}$, ddd, $J=16.7,6.8,5.7 \mathrm{~Hz}) .{ }^{13} \mathrm{C} \mathrm{NMR}\left(\mathrm{CDCl}_{3}, 100 \mathrm{MHz}\right): \delta 196.6,151.1,147.3,147.2$, 136.6, 136.2, 133.7, 128.9, 128.2, 127.6, 124.1, 121.2, 117.8, 111.4, 109.8, 55.6, 53.9, 46.2. HRMS (ES) Calcd for $\mathrm{C}_{22} \mathrm{H}_{20} \mathrm{~N}_{2} \mathrm{O}_{4} \mathrm{Na}$ : 399.1312; Found: 399.1321. $[\alpha]_{\mathrm{D}}{ }^{20}=-55.0^{\circ}$ $\left(c=0.58, \mathrm{CHCl}_{3}\right)$ for a $92 \%$ ee sample.

The optical purity of $\mathbf{4} \mathbf{c a}$ was established by chiral HPLC analysis (OD column, $1 / 1$ hexanes/ $i$-PrOH eluent, $1 \mathrm{~mL} / \mathrm{min}$ and a lamp setting of $254 \mathrm{~nm}$ ); chromatograms are shown below.
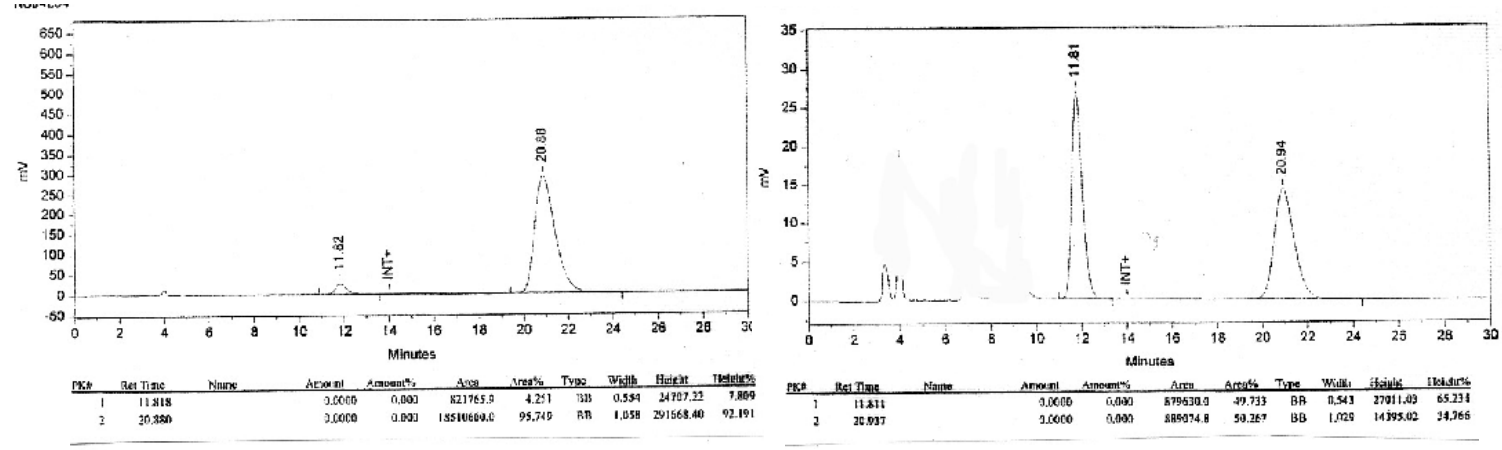

(-)-4-(2-Methoxyphenylamino)-4-(4-nitrophenyl)-butan-2-one (4cb); A modified procedure was used. Ligand $1(10 \mathrm{mg}, 20 \mu \mathrm{mol})$ and AgOAc (3.0 mg, $20 \mu \mathrm{mol})$ were OMe weighed into a $16 \times 150 \mathrm{~mm}$ test tube. The contents were dissolved in $0.4 \mathrm{~mL}$ of THF and allowed to stir for $5 \mathrm{~min}$ at $22^{\circ} \mathrm{C}$.

$\mathrm{NH} \quad \mathrm{O}$ Imine 2c (105 mg, $0.40 \mathrm{mmol})$ was added immediately followed by $33 \mu \mathrm{L} i$-PrOH $(0.45 \mathrm{mmol})$. The test tube was capped with a septum, and allowed to stir in a cold bath at $-10{ }^{\circ} \mathrm{C}$ for $5 \mathrm{~min}$. Enol $\mathrm{O}_{2} \mathrm{~N}$ ether $\mathbf{3 b}(130 \mu \mathrm{L}, 0.80 \mathrm{mmol})$ was added and the reaction was allowed to stir at $-10{ }^{\circ} \mathrm{C}$ for $16 \mathrm{~h}$. The reaction was quenched upon addition of $2 \mathrm{~mL}$ of $10 \%$ aqueous $\mathrm{HCl}$ followed by vigorous stirring for $5 \mathrm{~min} . \mathrm{CH}_{2} \mathrm{Cl}_{2}$ $(5 \mathrm{~mL})$ was added and the mixture was allowed to stir vigorously for $1 \mathrm{~min}$. The layers were allowed to separate, and the bottom layer $\left(\mathrm{CH}_{2} \mathrm{Cl}_{2}\right)$ was removed with a pipette and placed into a round-bottom flask. The aqueous layer was washed with $2 \times 5 \mathrm{~mL}$ portions of $\mathrm{CH}_{2} \mathrm{Cl}_{2}$ and separated as stated above. The combined organic layers were concentrated (without drying) and purified by silica gel chromatography (4:2 hexanes:EtOAc) to deliver $114 \mathrm{mg}(0.36 \mathrm{mmol}, 91 \%)$ of the desired product $\mathbf{4 c b}$ as a orange solid. IR (neat, $\mathrm{NaCl}): 1713(\mathrm{~m}), 1601(\mathrm{~m}), 1514(\mathrm{~s}), 1452(\mathrm{w}), 1346(\mathrm{~s}), 1228(\mathrm{~m}), 1022(\mathrm{w}), 742(\mathrm{~m})$. ${ }^{1} \mathrm{H} \mathrm{NMR}\left(\mathrm{CDCl}_{3}, 400 \mathrm{MHz}\right): \delta 8.15(2 \mathrm{H}, \mathrm{dd}, J=6.8,2.0 \mathrm{~Hz}), 7.55(2 \mathrm{H}, \mathrm{dd}, J=6.8,2.0$ $\mathrm{Hz}), 6.79-6.64(3 \mathrm{H}, \mathrm{m}), 6.29(1 \mathrm{H}, \mathrm{dd}, J=7.2,2.4 \mathrm{~Hz}), 4.99-4.96(2 \mathrm{H}, \mathrm{m}), 3.88(3 \mathrm{H}, \mathrm{s})$, 3.00 (2H, ddd, $J=16.7,7.0,5.9 \mathrm{~Hz}), 2.15(3 \mathrm{H}, \mathrm{s}) .{ }^{13} \mathrm{C}$ NMR $\left(\mathrm{CDCl}_{3}, 100 \mathrm{MHz}\right): \delta 205.6$, $150.8,147.3,147.1,136.0,127.5,124.1,121.2,117.9,111.4,109.8,55.6,53.6,51.2$, 
30.7. HRMS (ES) Calcd for $\mathrm{C}_{17} \mathrm{H}_{18} \mathrm{NO}_{2} \mathrm{NaCl}$ : 326.0927; Found: 326.0924. $[\alpha]_{\mathrm{D}}^{20}=$ $-38.0^{\circ}\left(c=0.93, \mathrm{CHCl}_{3}\right)$ for a $94 \%$ ee sample.

The optical purity of $\mathbf{4} \mathbf{c b}$ was established by chiral HPLC analysis (OJ column, 9/1 hexanes/ $i$-PrOH eluent, $1 \mathrm{~mL} / \mathrm{min}$ and a lamp setting of $254 \mathrm{~nm}$ ); chromatograms are shown below.
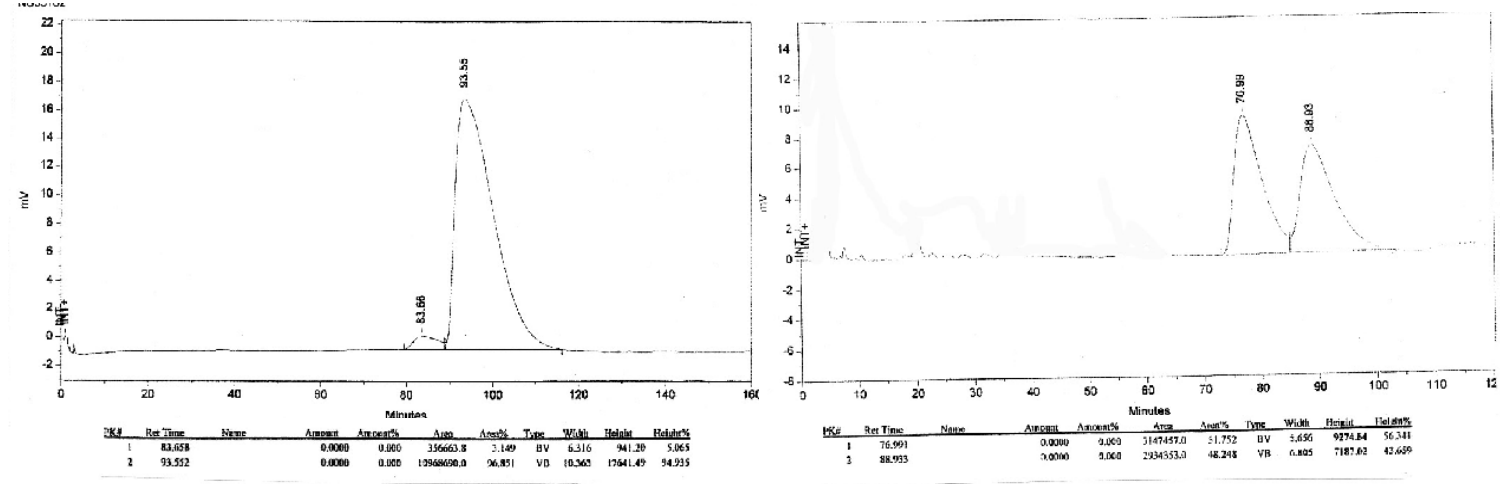

(-)-3-(4-Chlorophenyl)-3-(2-methoxyphenylamino)-1-phenylpropan-1-one

(4da);

$\mathrm{OMe}$

$\mathrm{Cl}$

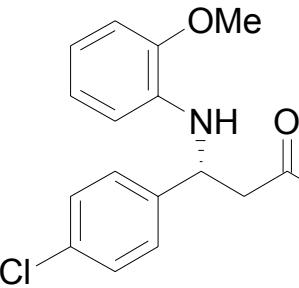

The representative procedure was followed. The crude product was purified by silica gel chromatography $\left(4: 2\right.$ hexanes:Et $\left.{ }_{2} \mathrm{O}\right)$ to deliver $370 \mathrm{mg}(1.0 \mathrm{mmol}, 83 \%)$ of the desired product $4 \mathbf{d a}$ as a orange solid. IR (neat, $\mathrm{NaCl}$ ): $1678(\mathrm{~s}), 1599(\mathrm{~s}), 1515$ (s), $1448(\mathrm{~m}), 1255$ (m), 1225 (s), 1032 (m), 737 (s). ${ }^{1} \mathrm{H}$ NMR $\left(\mathrm{CDCl}_{3}, 400 \mathrm{MHz}\right): \delta 7.90(2 \mathrm{H}, \mathrm{d}, J=8.0 \mathrm{~Hz}), 7.58-7.25(7 \mathrm{H}$, m), 6.77-6.62 $(3 \mathrm{H}, \mathrm{m}), 6.40(1 \mathrm{H}, \mathrm{d}, J=7.7 \mathrm{~Hz}), 5.05-5.03$

$(2 \mathrm{H}, \mathrm{m}), 3.85(3 \mathrm{H}, \mathrm{s}), 3.49(2 \mathrm{H}, \mathrm{ddd}, J=16.7,7.0,5.7 \mathrm{~Hz}) .{ }^{13} \mathrm{C} \mathrm{NMR}\left(\mathrm{CDCl}_{3}, 100\right.$ $\mathrm{MHz}): \delta 197.6,147.1,141.8,136.8,136.6,133.5,133.0,129.0,128.8,128.3,128.0$, 121.2, 117.3, 111.5, 109.6, 55.6, 53.9, 46.6. HRMS (ES) Calcd for $\mathrm{C}_{22} \mathrm{H}_{20} \mathrm{NO}_{2} \mathrm{NaCl}$ : 388.1070; Found: $388.1080 .[\alpha]_{\mathrm{D}}{ }^{20}=-53.7^{\circ}\left(c=0.947, \mathrm{CHCl}_{3}\right)$ for a $96 \%$ ee sample.

The optical purity of 4da was established by chiral HPLC analysis (OD column, $94 / 6$ hexanes/ $i$-PrOH eluent, $1 \mathrm{~mL} / \mathrm{min}$ and a lamp setting of $254 \mathrm{~nm}$ ); chromatograms are shown below.
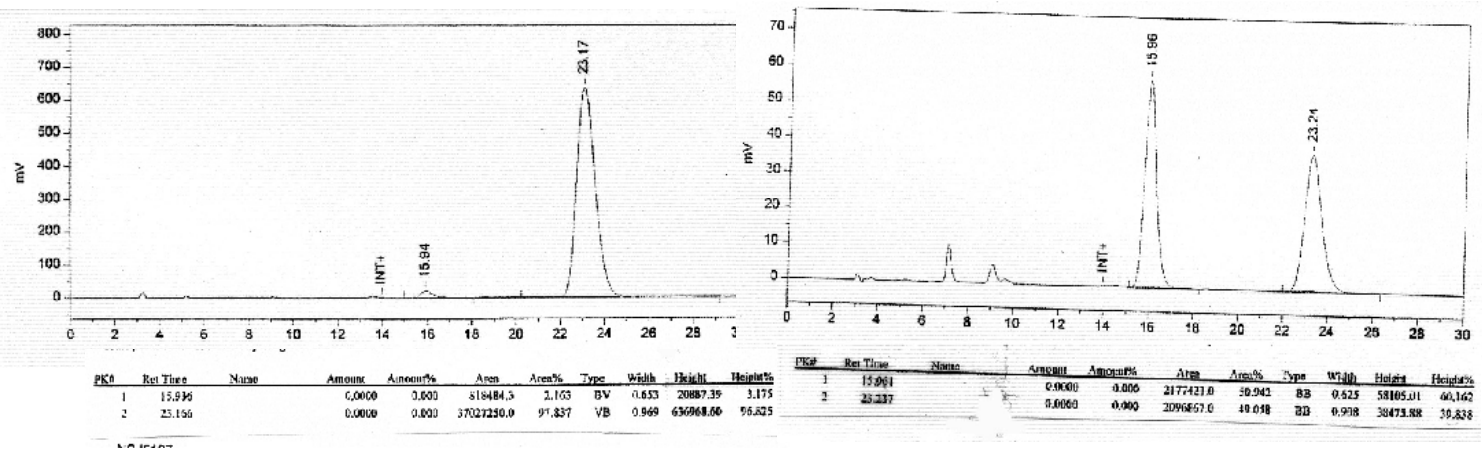

(-)-4-(4-Chlorophenyl)-4-(2-methoxyphenylamino)-butan-2-one (4db); A modified procedure was used. Ligand $1(10 \mathrm{mg}, 20 \mu \mathrm{mol})$ and AgOAc $(3.0 \mathrm{mg}, 20 \mu \mathrm{mol})$ were weighed into a $16 \times 150 \mathrm{~mm}$ test tube. The contents were dissolved in $0.4 \mathrm{~mL}$ of THF and $\mathrm{OMe}$ allowed to stir for $5 \mathrm{~min}$ at $22{ }^{\circ} \mathrm{C}$. Imine $2 \mathrm{~d}(100 \mathrm{mg}, 0.40 \mathrm{mmol})$

$\mathrm{NH} \mathrm{O}$ 
was added immediately followed by $33 \mu \mathrm{L} i-\mathrm{PrOH}(0.44 \mathrm{mmol})$. The test tube was capped with a septum, and allowed to stir in a cold bath at $-10^{\circ} \mathrm{C}$ for $5 \mathrm{~min}$. Enol ether $\mathbf{3 b}$ $(130 \mu \mathrm{L}, 0.80 \mathrm{mmol})$ was added and the reaction was allowed to stir at $-10^{\circ} \mathrm{C}$ for $16 \mathrm{~h}$. The reaction was quenched upon addition of $2 \mathrm{~mL}$ of $10 \%$ aqueous $\mathrm{HCl}$ followed by vigorous stirring for $5 \mathrm{~min}$. $\mathrm{CH}_{2} \mathrm{Cl}_{2}(5 \mathrm{~mL})$ was added and the mixture was allowed to stir vigorously for $1 \mathrm{~min}$. The layers were allowed to separate, and the bottom layer $\left(\mathrm{CH}_{2} \mathrm{Cl}_{2}\right)$ was removed with a pipette and placed into a round-bottom flask. The aqueous layer was washed with $2 \times 5 \mathrm{~mL}$ portions of $\mathrm{CH}_{2} \mathrm{Cl}_{2}$ and separated as stated above. The combined organic layers were concentrated (without drying) and purified by silica gel chromatography (4:2 hexanes:EtOAc) to deliver $96 \mathrm{mg}(0.32 \mathrm{mmol}, 79 \%)$ of the desired product $4 \mathbf{d b}$ as a clear colorless oil. IR (neat, $\mathrm{NaCl}$ ): 1712 (s), 1607 (m), 1509 (s), 1607 (m), $1226(\mathrm{~s}), 1029(\mathrm{~m}), 740(\mathrm{~m}) .{ }^{1} \mathrm{H}$ NMR $\left(\mathrm{CDCl}_{3}, 400 \mathrm{MHz}\right): \delta$ 7.30-7.24 (4H, m), 6.76-6.61 (3H, m), $6.35(1 \mathrm{H}, \mathrm{dd}, J=7.7,1.6 \mathrm{~Hz}), 4.85-4.82(2 \mathrm{H}, \mathrm{m}), 3.85(3 \mathrm{H}, \mathrm{s}), 2.92$ $(2 \mathrm{H}$, ddd, $J=16.1,7.1,5.5 \mathrm{~Hz}), 2.10(3 \mathrm{H}, \mathrm{s}) .{ }^{13} \mathrm{C} \mathrm{NMR}\left(\mathrm{CDCl}_{3}, 100 \mathrm{MHz}\right): \delta 206.4$, $147.1,141.5,136.5,133.0,129.0,127.9,121.2,117.4,111.4,109.7,55.6,53.6,51.7$, 30.8. HRMS (ES) Calcd for $\mathrm{C}_{17} \mathrm{H}_{18} \mathrm{NO}_{2} \mathrm{NaCl}$ : 326.0923; Found: $326.0925 .[\alpha]_{\mathrm{D}}^{20}=$ $-36.6^{\circ}\left(c=0.970, \mathrm{CHCl}_{3}\right)$ for a $90 \%$ ee sample.

The optical purity of $\mathbf{4 d b}$ was established by chiral HPLC analysis (OD column, 9/1 hexanes/ $i$-PrOH eluent, $1 \mathrm{~mL} / \mathrm{min}$ and a lamp setting of $254 \mathrm{~nm}$ ); chromatograms are shown below.
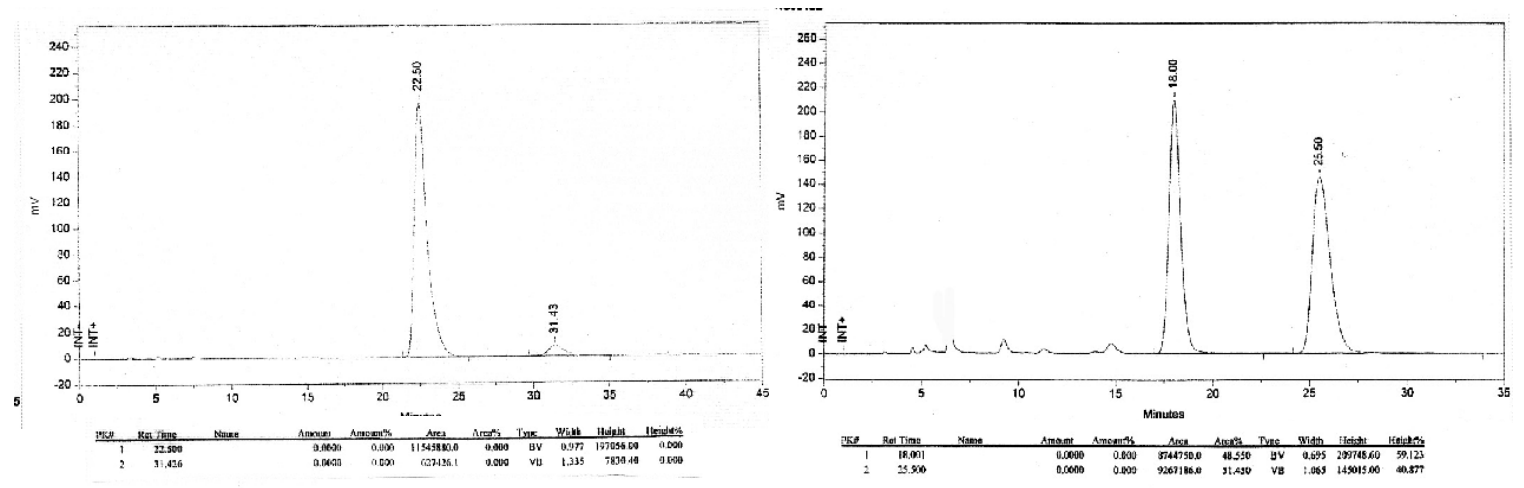

(-)-3-(2-Methoxyphenylamino)-3-(3-nitrophenyl)-1-phenylpropan-1-one (4ea); A

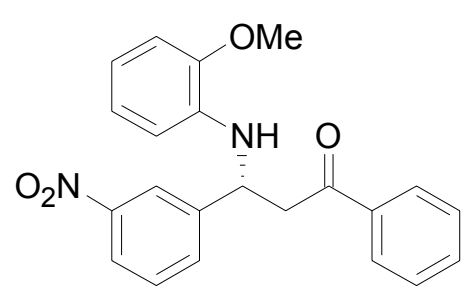
modified procedure was used. Ligand $1(6.0 \mathrm{mg}, 12 \mu \mathrm{mol})$ and $\mathrm{AgOAc}(2.0 \mathrm{mg}, 12 \mu \mathrm{mol})$ were weighed into a $16 \times 150$ $\mathrm{mm}$ test tube. The contents were dissolved in $0.2 \mathrm{~mL}$ of THF and allowed to stir for $5 \mathrm{~min}$ at $22^{\circ} \mathrm{C}$. Imine $2 \mathrm{e}(115 \mathrm{mg}$, $0.40 \mathrm{mmol})$ was added immediately followed by $33 \mu \mathrm{L} i$ $\mathrm{PrOH}(0.45 \mathrm{mmol})$. The test tube was capped with a septum, and allowed to stir in a cold bath at $-10{ }^{\circ} \mathrm{C}$ for $5 \mathrm{~min}$. Enol ether 3a $(160 \mu \mathrm{L}, 0.80 \mathrm{mmol})$ was added and the reaction was allowed to stir at $-10^{\circ} \mathrm{C}$ for $16 \mathrm{~h}$. The reaction was quenched upon addition of $2 \mathrm{~mL}$ of $10 \%$ aqueous $\mathrm{HCl}$ followed by vigorous stirring for $5 \mathrm{~min}$. $\mathrm{CH}_{2} \mathrm{Cl}_{2}(5 \mathrm{~mL})$ was added and the mixture was allowed to stir vigorously for $1 \mathrm{~min}$. The layers were allowed to separate, and the bottom layer $\left(\mathrm{CH}_{2} \mathrm{Cl}_{2}\right)$ was removed with a pipette and placed into a round-bottom flask. The aqueous layer was washed with $2 \times 5 \mathrm{~mL}$ portions of $\mathrm{CH}_{2} \mathrm{Cl}_{2}$ and separated as stated above. The combined organic layers were concentrated (without drying) and purified by silica gel 
chromatography (4:2 hexanes: $\left.\mathrm{Et}_{2} \mathrm{O}\right)$ to deliver $162 \mathrm{mg}(0.15 \mathrm{mmol}, 97 \%)$ of the desired product 4ea as a orange solid. IR (neat, $\mathrm{NaCl}$ ): $1683(\mathrm{~s}), 1597(\mathrm{~m}), 1529(\mathrm{~s}), 1449(\mathrm{~m})$, $1344(\mathrm{~s}), 1226(\mathrm{~m}), 738(\mathrm{~s}) .{ }^{1} \mathrm{H}$ NMR $\left(\mathrm{CDCl}_{3}, 400 \mathrm{MHz}\right): \delta 8.33(1 \mathrm{H}, \mathrm{s}), 8.07(1 \mathrm{H}, \mathrm{dd}, J$ $=8.1,1.5 \mathrm{~Hz}), 7.92(2 \mathrm{H}, \mathrm{dd}, J=8.1,1.3 \mathrm{~Hz}), 7.82(1 \mathrm{H}, \mathrm{d}, J=7.7 \mathrm{~Hz}), 7.60-7.44(4 \mathrm{H}, \mathrm{m})$, 6.79-6.65 (3H, m), $6.39(1 \mathrm{H}, \mathrm{dd}, J=7.5,1.8 \mathrm{~Hz}), 5.17(1 \mathrm{H}$, apparent doublet, $J=6.2$ $\mathrm{Hz}), 5.12(1 \mathrm{H}, \mathrm{br}), 3.88(3 \mathrm{H}, \mathrm{s}), 3.57(2 \mathrm{H}, \mathrm{ddd}, J=16.7,6.8,5.9 \mathrm{~Hz}) .{ }^{13} \mathrm{C} \mathrm{NMR}\left(\mathrm{CDCl}_{3}\right.$, $100 \mathrm{MHz}): \delta 197.0,148.8,147.2,145.8,136.6,136.2,133.7,133.3,129.8,128.9,128.3$, 122.6, 121.6, 121.2, 117.8, 111.5, 109.8, 55.7, 53.9, 46.4. HRMS (ES) Calcd for $\mathrm{C}_{22} \mathrm{H}_{20} \mathrm{~N}_{2} \mathrm{O}_{4} \mathrm{Na}$ : 399.1316; Found: 399.1321. Anal Calcd for $\mathrm{C}_{22} \mathrm{H}_{20} \mathrm{~N}_{2} \mathrm{O}_{4}$ : C, 70.20, H, 5.36; Found: $\mathrm{C}, 70.15, \mathrm{H}, 5.20 .[\alpha]_{\mathrm{D}}{ }^{20}=-61.8^{\circ}\left(c=0.630, \mathrm{CHCl}_{3}\right)$ for a $86 \%$ ee sample.

The optical purity of $\mathbf{4}$ ea was established by chiral HPLC analysis (OD column, $75 / 25$ hexanes/ $i$-PrOH eluent, $1 \mathrm{~mL} / \mathrm{min}$ and a lamp setting of $254 \mathrm{~nm}$ ); chromatograms are shown below.
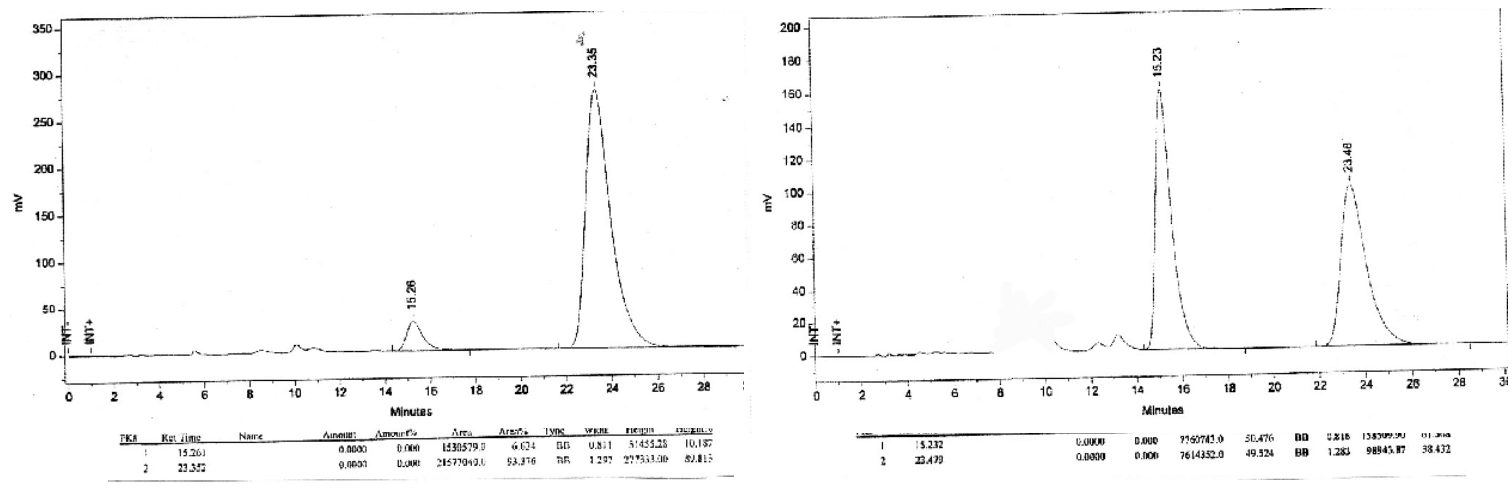

(-)-4-(2-Methoxyphenylamino)-4-(3-nitrophenyl)-butan-2-one (4eb); A modified procedure was used. Ligand $1(6.0 \mathrm{mg}, 12 \mu \mathrm{mol})$ and AgOAc $(2.0 \mathrm{mg}, 12 \mu \mathrm{mol})$ were weighed into a $16 \times 150 \mathrm{~mm}$ test tube. The contents were
dissolved in $0.4 \mathrm{~mL}$ of THF and allowed to stir for $5 \mathrm{~min}$ at $22^{\circ} \mathrm{C}$. was allowed to stir at $-5^{\circ} \mathrm{C}$ for $16 \mathrm{~h}$. The reaction was quenched upon addition of $2 \mathrm{~mL}$ of $10 \%$ aqueous $\mathrm{HCl}$ followed by vigorous stirring for $5 \mathrm{~min}$. $\mathrm{CH}_{2} \mathrm{Cl}_{2}(5 \mathrm{~mL})$ was added and the mixture was allowed to stir vigorously for $1 \mathrm{~min}$. The layers were allowed to separate, and the bottom layer $\left(\mathrm{CH}_{2} \mathrm{Cl}_{2}\right)$ was removed with a pipette and placed into a round-bottom flask. The aqueous layer was washed with $2 \times 5 \mathrm{~mL}$ portions of $\mathrm{CH}_{2} \mathrm{Cl}_{2}$ and separated as stated above. The combined organic layers were concentrated (without drying) and purified by silica gel chromatography (4:2 hexanes:EtOAc) to deliver $121 \mathrm{mg}$ $(0.380 \mathrm{mmol}, 96 \%)$ of the desired product $4 \mathbf{e b}$ as a yellow oil. IR (neat, $\mathrm{NaCl}): 1712(\mathrm{~m})$,

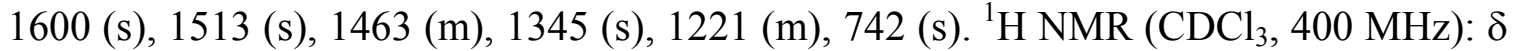
$8.25(1 \mathrm{H}, \mathrm{s}), 8.10-8.07(1 \mathrm{H}, \mathrm{m}), 7.74(1 \mathrm{H}, \mathrm{d}, J=7.7 \mathrm{~Hz}), 7.48(1 \mathrm{H}, \mathrm{t}, J=7.9 \mathrm{~Hz}), 6.79-$ $6.64(3 \mathrm{H}, \mathrm{m}), 6.35(1 \mathrm{H}, \mathrm{dd}, J=7.3,1.8 \mathrm{~Hz}), 5.10-4.97(2 \mathrm{H}, \mathrm{m}), 3.89(3 \mathrm{H}, \mathrm{s}), 3.02(2 \mathrm{H}$, ddd, $J=16.7,7.1,5.7 \mathrm{~Hz}), 2.16(3 \mathrm{H}, \mathrm{s}) .{ }^{13} \mathrm{C} \mathrm{NMR}\left(\mathrm{CDCl}_{3}, 100 \mathrm{MHz}\right): \delta 205.7,148.8$, $147.2,145.5,136.0,133.1,129.8,122.6,121.5,121.2,117.9,111.5,109.8,55.7,53.6$, 
51.4, 30.7. HRMS (ES) Calcd for $\mathrm{C}_{17} \mathrm{H}_{18} \mathrm{~N}_{2} \mathrm{O}_{4} \mathrm{Na}$ : 337.1162; Found: 337.1164. $[\alpha]_{\mathrm{D}}{ }^{20}=$ $-42.3^{\circ}\left(c=0.68, \mathrm{CHCl}_{3}\right)$ for a $86 \%$ ee sample.

The optical purity of $\mathbf{4 e b}$ was established by chiral HPLC analysis (OD column, $75 / 25$ hexanes/ $i$-PrOH eluent, $1 \mathrm{~mL} / \mathrm{min}$ and a lamp setting of $254 \mathrm{~nm}$ ); chromatograms are shown below.
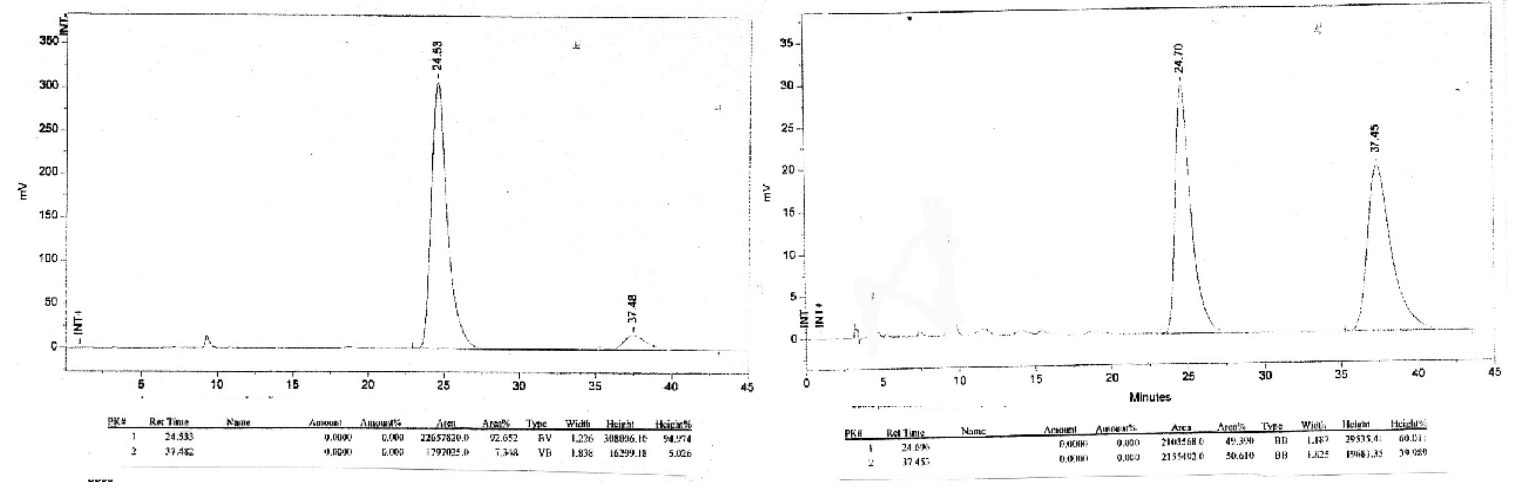

(-)-3-(2-Methoxyphenylamino)-3-naphthalen-2-yl-1-phenylpropan-1-one (4fa); A

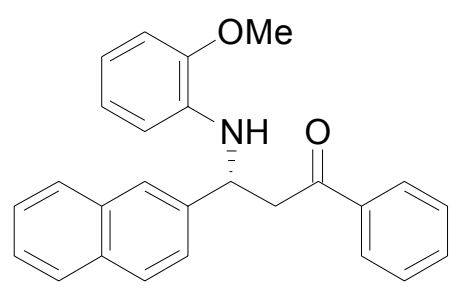
modified procedure was used. Ligand $1(6.0 \mathrm{mg}, 12 \mu \mathrm{mol})$ and $\mathrm{AgOAc}(2.0 \mathrm{mg}, 12 \mu \mathrm{mol})$ were weighed into a $16 \times 150$ $\mathrm{mm}$ test tube. The contents were dissolved in $0.4 \mathrm{~mL}$ of THF and allowed to stir for $5 \mathrm{~min}$ at $22^{\circ} \mathrm{C}$. Imine $2 \mathrm{f}(105 \mathrm{mg}$, $0.40 \mathrm{mmol})$ was added immediately followed by $33 \mu \mathrm{L} i$ PrOH $(0.45 \mathrm{mmol})$. The test tube was capped with a septum, and allowed to stir in a cold bath at $-5{ }^{\circ} \mathrm{C}$ for $5 \mathrm{~min}$. Enol ether 3a (160 $\mu \mathrm{L}, 0.8 \mathrm{mmol})$ was added and the reaction mixture was allowed to stir at -5 ${ }^{\circ} \mathrm{C}$ for $16 \mathrm{~h}$. The reaction was quenched upon addition of $2 \mathrm{~mL}$ of $10 \%$ aqueous $\mathrm{HCl}$ followed by vigorous stirring for $5 \mathrm{~min}$. $\mathrm{CH}_{2} \mathrm{Cl}_{2}(5 \mathrm{~mL})$ was added and the mixture was allowed to stir vigorously for $1 \mathrm{~min}$. The layers were allowed to separate, and the bottom layer $\left(\mathrm{CH}_{2} \mathrm{Cl}_{2}\right)$ was removed with a pipette and placed into a round-bottom flask. The aqueous layer was washed with $2 \times 5 \mathrm{~mL}$ portions of $\mathrm{CH}_{2} \mathrm{Cl}_{2}$ and separated as stated above. The combined organic layers were concentrated (without drying) and purified by silica gel chromatography (4:1 hexanes:EtOAc) to deliver $135 \mathrm{mg}(0.35 \mathrm{mmol}, 88 \%)$ of the desired product $\mathbf{4 f a}$ as a white solid. IR (neat, $\mathrm{NaCl}$ ): 3413 (w), 3057 (w), 1684 (s), 1602 (s), 1517 (s), 1453 (m), 1222 (s), 1028 (m), 747 (s). ${ }^{1} \mathrm{H}$ NMR $\left(\mathrm{CDCl}_{3}, 400 \mathrm{MHz}\right): \delta$ 8.10-7.43 $(12, \mathrm{~m}), 6.80-6.62(3 \mathrm{H}, \mathrm{m}), 6.53(1 \mathrm{H}, \mathrm{dd}, J=7.7,1.5 \mathrm{~Hz}), 5.25(1 \mathrm{H}$, apparent triplet, $J=6.4 \mathrm{~Hz}), 5.11(1 \mathrm{H}, \mathrm{br}), 3.89(3 \mathrm{H}, \mathrm{s}), 3.61(2 \mathrm{H}$, apparent doublet, $J=6.4 \mathrm{~Hz})$. ${ }^{13} \mathrm{C} \mathrm{NMR}\left(\mathrm{CDCl}_{3}, 100 \mathrm{MHz}\right): \delta$ 197.9, 147.1, 140.8, 137.0, 136.9, 133.6, 133.4, 133.0, 128.8, 128.6, 128.3, 128.0, 127.8, 126.1, 125.8, 125.3, 124.8, 121.2, 117.1, 111.6, 109.6, 55.6, 54.7, 46.8. HRMS (ES) Calcd for $\mathrm{C}_{26} \mathrm{H}_{23} \mathrm{NO}_{2} \mathrm{Na}$ : 404.1632; Found: 404.1626. $[\alpha]_{\mathrm{D}}^{20}=-53.57^{\circ}\left(c=1.37, \mathrm{CHCl}_{3}\right)$ for a $96 \%$ ee sample.

The optical purity of $\mathbf{4 f a}$ was established by chiral HPLC analysis (OD column, $1 / 1$ hexanes/ $i$ - $\mathrm{PrOH}$ eluent, $1 \mathrm{~mL} / \mathrm{min}$ and a lamp setting of $254 \mathrm{~nm}$ ); chromatograms are shown below. 

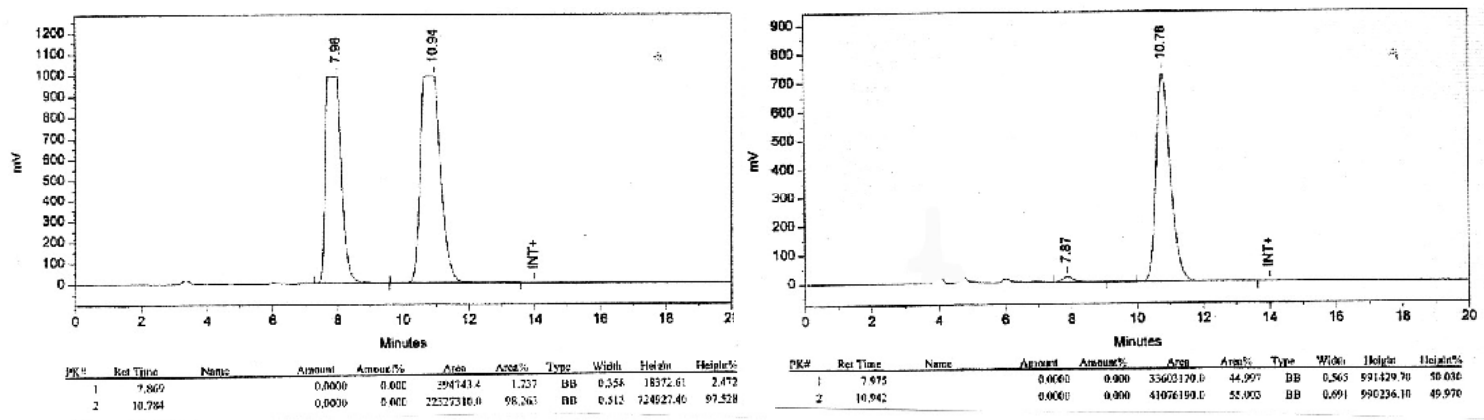

(-)-4-(2-Methoxyphenylamino)-4-naphthalen-2-yl-butan-2-one (4fb); A modified procedure was used. Ligand $1(6.0 \mathrm{mg}, 12 \mu \mathrm{mol})$ and AgOAc (2.0

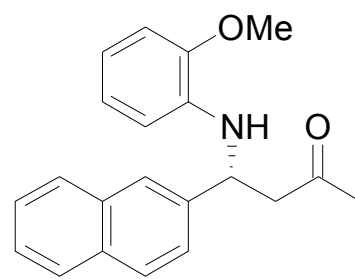
$\mathrm{mg}, 12 \mu \mathrm{mol})$ were weighed into a $16 \times 150 \mathrm{~mm}$ test tube. The contents were dissolved in $0.4 \mathrm{~mL}$ of THF and allowed to stir for 5 min at $22{ }^{\circ} \mathrm{C}$. Imine $2 \mathbf{f}(105 \mathrm{mg}, 0.40 \mathrm{mmol})$ was added immediately followed by $33 \mu \mathrm{L} i$-PrOH $(0.45 \mathrm{mmol})$. The test tube was capped with a septum, and allowed to stir in a cold bath at $-5{ }^{\circ} \mathrm{C}$ for $5 \mathrm{~min}$. Enol ether $\mathbf{3 b}(130 \mu \mathrm{L}, 0.80 \mathrm{mmol})$ was added and the reaction mixture was allowed to stir at $-5{ }^{\circ} \mathrm{C}$ for $16 \mathrm{~h}$. The reaction was quenched upon addition of $2 \mathrm{~mL}$ of $10 \%$ aqueous $\mathrm{HCl}$ followed by vigorous stirring for $5 \mathrm{~min}$. $\mathrm{CH}_{2} \mathrm{Cl}_{2}(5 \mathrm{~mL})$ was added and the mixture was allowed to stir vigorously for $1 \mathrm{~min}$. The layers were allowed to separate, and the bottom layer $\left(\mathrm{CH}_{2} \mathrm{Cl}_{2}\right)$ was removed with a pipette and placed into a round-bottom flask. The aqueous layer was washed with $2 \times 5$ $\mathrm{mL}$ portions of $\mathrm{CH}_{2} \mathrm{Cl}_{2}$ and separated as stated above. The combined organic layers were concentrated (without drying) and purified by silica gel chromatography (4:2 hexanes:EtOAc) to deliver $120 \mathrm{mg}(0.38 \mathrm{mmol}, 94 \%)$ of the desired product $\mathbf{4 f b}$ as a white solid. IR (neat, $\mathrm{NaCl}$ ): 3412 (w), 3049 (w), 1714 (s), 1599 (s), 1515 (s), 1460 (m), $1218(\mathrm{~m}), 1128(\mathrm{~m}), 1031(\mathrm{~m}), 735$ (s). ${ }^{1} \mathrm{H}$ NMR $\left(\mathrm{CDCl}_{3}, 400 \mathrm{MHz}\right): \delta$ 7.85-7.81 (4H,m), 7.53-7.44 (3H, m), 6.79( 1H, dd, $J=7.2,1.1 \mathrm{~Hz}), 6.73-6.62(2 \mathrm{H}, \mathrm{m}), 6.51(1 \mathrm{H}, \mathrm{dd}, J=$ $7.2,1.4 \mathrm{~Hz}), 5.06(1 \mathrm{H}, \mathrm{dd}, J=6.8,6.4 \mathrm{~Hz}), 5.01(1 \mathrm{H}, \mathrm{s}), 3.91(3 \mathrm{H}, \mathrm{s}), 3.05(2 \mathrm{H}, \mathrm{ddd}, J=$ 14.0, 7.1, 6.0 Hz), $2.13(3 \mathrm{H}, \mathrm{s}) .{ }^{13} \mathrm{C} \mathrm{NMR}\left(\mathrm{CDCl}_{3}, 100 \mathrm{MHz}\right): \delta 206.7,147.1,140.4$, $136.8,133.6,132.9,128.8,128.0,127.8,126.2,125.9,125.2,124.5,121.2,117.2,111.5$, 109.6, 55.6, 54.4, 51.8, 30.8. HRMS (ES) Calcd for $\mathrm{C}_{21} \mathrm{H}_{21} \mathrm{NO}_{2} \mathrm{Na}$ : 342.1464; Found: $342.1470 .[\alpha]_{\mathrm{D}}{ }^{20}=-55.5^{\circ}\left(c=0.40, \mathrm{CHCl}_{3}\right)$ for a $92 \%$ ee sample.

The optical purity of $\mathbf{4 f b}$ was established by chiral HPLC analysis (OD column, 9/1 hexanes/ $i$-PrOH eluent, $1 \mathrm{~mL} / \mathrm{min}$ and a lamp setting of $254 \mathrm{~nm}$ ); chromatograms are shown below. 

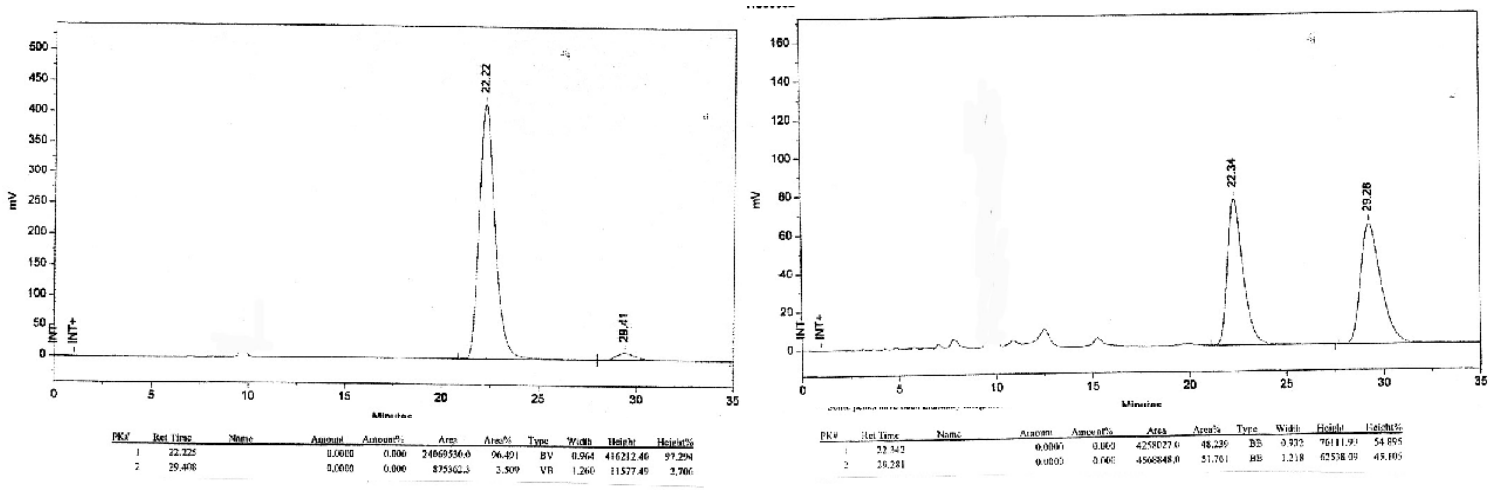

(-)-3-(2-Bromophenyl)-3-(2-methoxyphenylamino)-1-phenylpropan-1-one (4ga); A

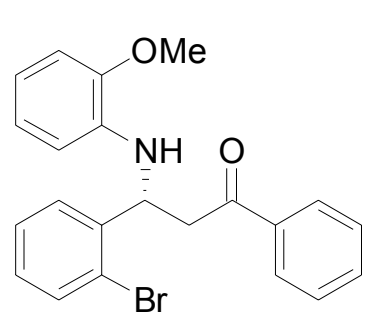
modified procedure was used. Ligand $1(10 \mathrm{mg}, 20 \mu \mathrm{mol})$ and AgOAc $(3.0 \mathrm{mg}, 20 \mu \mathrm{mol})$ were weighed into a $16 \times 150 \mathrm{~mm}$ test tube. The contents were dissolved in $0.4 \mathrm{~mL}$ of toluene and allowed to stir for $5 \mathrm{~min}$ at $23{ }^{\circ} \mathrm{C}$. Imine $2 \mathrm{~g}$ (115 $\mathrm{mg}, 0.40 \mathrm{mmol}$ ) was added immediately followed by $33 \mu \mathrm{L} i$-PrOH $(0.45 \mathrm{mmol})$. The test tube was capped with a septum, and allowed to stir $23{ }^{\circ} \mathrm{C}$ for $5 \mathrm{~min}$. Enol ether $3 \mathbf{a}(160 \mu \mathrm{L}, 0.80 \mathrm{mmol})$ was added and the reaction mixture was allowed to stir at $23{ }^{\circ} \mathrm{C}$ for $16 \mathrm{~h}$. The reaction was quenched upon addition of $2 \mathrm{~mL}$ of $10 \%$ aqueous $\mathrm{HCl}$ followed by vigorous stirring for $5 \mathrm{~min} . \mathrm{CH}_{2} \mathrm{Cl}_{2}$ $(5 \mathrm{~mL})$ was added and the mixture was allowed to stir vigorously for $1 \mathrm{~min}$. The layers were allowed to separate, and the bottom layer $\left(\mathrm{CH}_{2} \mathrm{Cl}_{2}\right)$ was removed with a pipette and placed into a round-bottom flask. The aqueous layer was washed with $2 \times 5 \mathrm{~mL}$ portions of $\mathrm{CH}_{2} \mathrm{Cl}_{2}$ and separated as stated above. The combined organic layers were concentrated (without drying) and purified by silica gel chromatography (8:2 hexanes: $\left.\mathrm{Et}_{2} \mathrm{O}\right)$ to deliver $64 \mathrm{mg}(0.63 \mathrm{mmol}, 46 \%)$ of the desired product $4 \mathrm{ga}$ as a white solid. IR (neat, $\mathrm{NaCl}$ ): 3410 (w), 1686 (s), 1599 (s), 1512 (s), 1456 (m), 1258 (m), 1221 (s), 1022 (s), 737 (s). ${ }^{1} \mathrm{H}$ NMR $\left(\mathrm{CDCl}_{3}, 400 \mathrm{MHz}\right): \delta 7.99(2 \mathrm{H}, \mathrm{d}, J=7.1 \mathrm{~Hz}), 7.58-7.43(5 \mathrm{H}, \mathrm{m}), 7.21(1 \mathrm{H}, \mathrm{dt}, J=$ 7.5, $1.3 \mathrm{~Hz}), 7.09(1 \mathrm{H}, \mathrm{dt}, J=7.7,1.6 \mathrm{~Hz}), 6.76-6.59(3 \mathrm{H}, \mathrm{m}), 6.22(1 \mathrm{H}, \mathrm{dd}, J=7.7,1.4$ $\mathrm{Hz}), 5.38(1 \mathrm{H}, \mathrm{br}), 5.32(1 \mathrm{H}, \mathrm{dd}, J=8.9,3.5 \mathrm{~Hz}), 3.88(3 \mathrm{H}, \mathrm{s}), 3.58(1 \mathrm{H}, \mathrm{dd}, J=15.7,3.7$ $\mathrm{Hz}), 3.37(1 \mathrm{H}, \mathrm{dd}, J=15.7,8.8 \mathrm{~Hz}) .{ }^{13} \mathrm{C} \mathrm{NMR}\left(\mathrm{CDCl}_{3}, 100 \mathrm{MHz}\right): \delta 198.1,147.2,141.4$, $136.8,135.4,133.5,133.2,129.0,128.8,128.5,128.4,128.2,122.9,121.2,117.2,111.5$, 109.6, 55.7, 54.0, 44.4. HRMS (ES) Calcd for $\mathrm{C}_{22} \mathrm{H}_{20} \mathrm{NO}_{2} \mathrm{NaBr}$ : 432.0583; Found: 432.0575. $[\alpha]_{\mathrm{D}}{ }^{20}=-89.1^{\circ}\left(c=1.85, \mathrm{CHCl}_{3}\right)$ for a $76 \%$ ee sample.

The optical purity of 4ga was established by chiral HPLC analysis (OD column, 9/1 hexanes/ $i$-PrOH eluent, $1 \mathrm{~mL} / \mathrm{min}$ and a lamp setting of $254 \mathrm{~nm}$ ); chromatograms are shown below. 

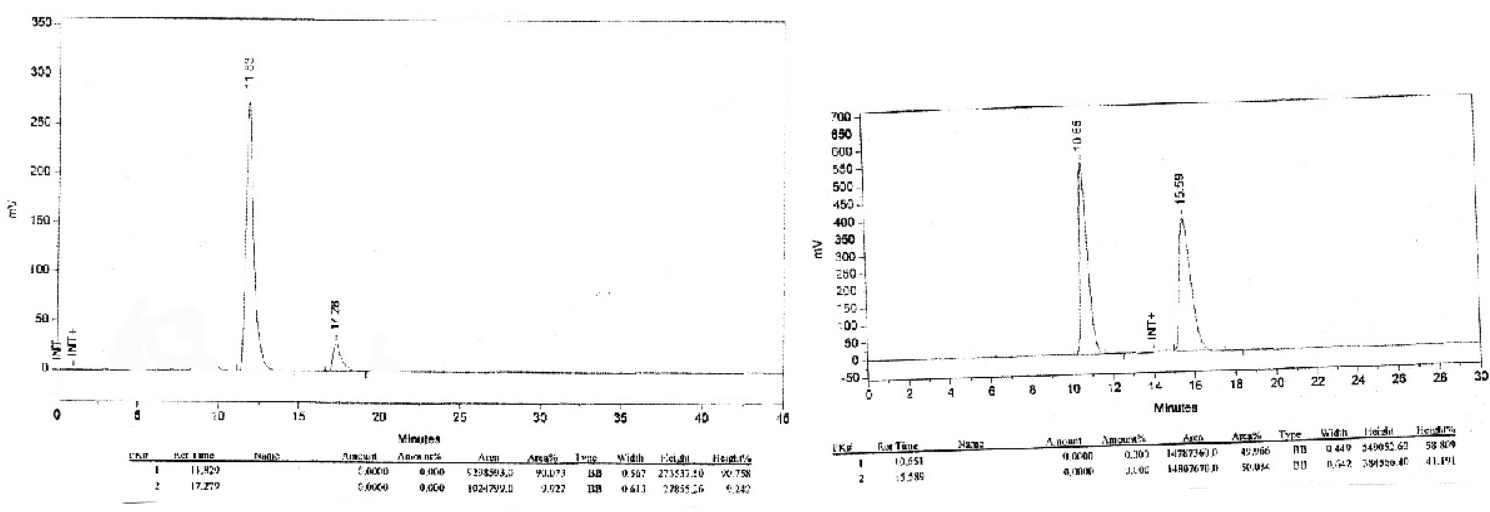

(-)-4-(2-Bromophenyl)-4-(2-methoxyphenylamino)-butan-2-one (4gb); A modified OMe procedure was used. Ligand $1(10 \mathrm{mg}, 20 \mu \mathrm{mol})$ and AgOAc (3.0 mg, $\overbrace{\mathrm{Br}}^{\mathrm{OMe}}$ $20 \mu \mathrm{mol})$ were weighed into a $16 \times 150 \mathrm{~mm}$ test tube. The contents were dissolved in $0.4 \mathrm{~mL}$ of THF and allowed to stir for $5 \mathrm{~min}$ at $22{ }^{\circ} \mathrm{C}$. Imine $2 \mathbf{g}$ (115 $\mathrm{mg}, 0.40 \mathrm{mmol})$ was added immediately followed by 33 $\mu \mathrm{L} i$-PrOH $(0.45 \mathrm{mmol})$. The test tube was capped with a septum, and allowed to stir in a cold room at $4{ }^{\circ} \mathrm{C}$ for $5 \mathrm{~min}$. Enol ether $3 \mathbf{b}(130 \mu \mathrm{L}$, $0.80 \mathrm{mmol}$ ) was added and the reaction mixture was allowed to stir at 4

${ }^{\circ} \mathrm{C}$ for $16 \mathrm{~h}$. The reaction was quenched upon addition of $2 \mathrm{~mL}$ of $10 \%$ aqueous $\mathrm{HCl}$ followed by vigorous stirring for $5 \mathrm{~min}$. $\mathrm{CH}_{2} \mathrm{Cl}_{2}(5 \mathrm{~mL})$ was added and the mixture was allowed to stir vigorously for $1 \mathrm{~min}$. The layers were allowed to separate, and the bottom layer $\left(\mathrm{CH}_{2} \mathrm{Cl}_{2}\right)$ was removed with a pipette and placed into a round-bottom flask. The aqueous layer was washed with $2 \times 5 \mathrm{~mL}$ portions of $\mathrm{CH}_{2} \mathrm{Cl}_{2}$ and separated as stated above. The combined organic layers were concentrated (without drying) and purified by silica gel chromatography (4:2 hexanes:EtOAc) to deliver $97 \mathrm{mg}(0.28 \mathrm{mmol}, 70 \%)$ of the desired product $\mathbf{4 g b}$ as a clear colorless oil. IR (neat, $\mathrm{NaCl}$ ): $3414(\mathrm{~m}), 2928(\mathrm{w})$, 1713 (s), 1601 (m), 1514 (s), 1452 (s), 1352 (m), 1228 (s), 1022 (m), 735 (s). ${ }^{1} \mathrm{H}$ NMR $\left(\mathrm{CDCl}_{3}, 400 \mathrm{MHz}\right): \delta 7.56(1 \mathrm{H}, \mathrm{dd}, J=6.9,0.4 \mathrm{~Hz}), 7.41(1 \mathrm{H}, \mathrm{dd}, J=7.8,1.6 \mathrm{~Hz}), 7.22$ $(1 \mathrm{H}, \mathrm{t}, J=7.5 \mathrm{~Hz}), 7.09(1 \mathrm{H}, \mathrm{t}, J=7.5 \mathrm{~Hz}), 6.77-6.61(3 \mathrm{H}, \mathrm{m}), 6.22,(1 \mathrm{H}, \mathrm{dd}, J=7.6,1.5$ $\mathrm{Hz}), 5.19(1 \mathrm{H}, \mathrm{dd}, J=9.5,3.6 \mathrm{~Hz}), 5.10-5.00(1 \mathrm{H}, \mathrm{br}), 3.89(3 \mathrm{H}, \mathrm{s}), 3.03(1 \mathrm{H}, \mathrm{dd}, J=$ 15.6, $3.6 \mathrm{~Hz}), 2.76(1 \mathrm{H}, \mathrm{dd}, J=15.6,9.5 \mathrm{~Hz}), 2.21(3 \mathrm{H}, \mathrm{s}) .{ }^{13} \mathrm{C} \mathrm{NMR}\left(\mathrm{CDCl}_{3}, 100 \mathrm{MHz}\right)$ : $\delta$ 206.9, 147.2, 140.9, 136.1, 133.2, 129.0, 128.2, 127.9, 122.9, 121.3, 117.5, 111.5, 109.6, 55.7, 53.8, 49.8, 30.0. HRMS (ES) Calcd for $\mathrm{C}_{17} \mathrm{H}_{18} \mathrm{NO}_{2} \mathrm{NaBr}$ : 370.0410; Found: 370.0419. Anal Calcd for $\mathrm{C}_{17} \mathrm{H}_{18} \mathrm{BrNO}_{2}$ : C, 58.63, H, 5.21; Found: C, 59.03, H, 5.00. $[\alpha]_{\mathrm{D}}{ }^{20}=-89.5^{\circ}\left(c=0.62, \mathrm{CHCl}_{3}\right)$ for a $80 \%$ ee sample.

The optical purity of $\mathbf{4 g b}$ was established by chiral HPLC analysis (OD column, 9/1 hexanes/ $i$-PrOH eluent, $1 \mathrm{~mL} / \mathrm{min}$ and a lamp setting of $254 \mathrm{~nm}$ ); chromatograms are shown below. 

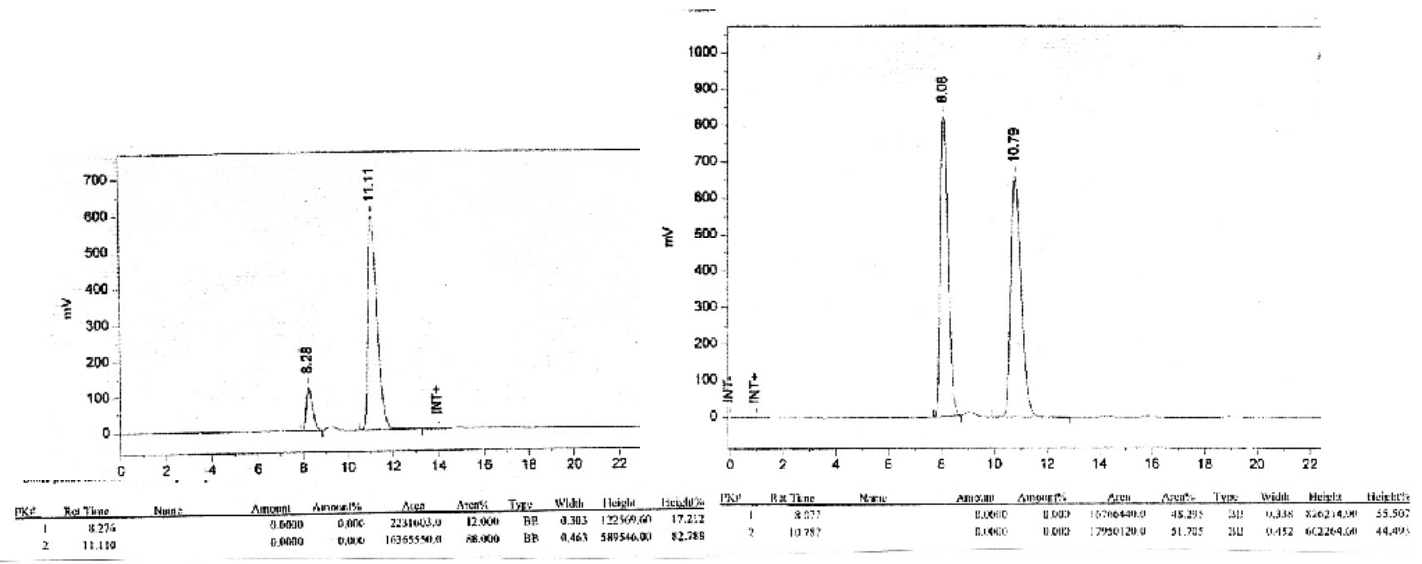

(+)-3-Furan-2-yl-3-(2-methoxyphenylamino)-1-phenylpropan-1-one (4ha); A modified procedure was used. Ligand $1(6.0 \mathrm{mg}, 12 \mu \mathrm{mol})$ and AgOAc $(2.0 \mathrm{mg}, 12$

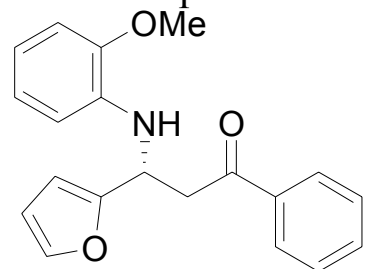
$\mu \mathrm{mol})$ were weighed into a $16 \times 150 \mathrm{~mm}$ test tube. The contents were dissolved in $0.4 \mathrm{~mL}$ of THF and allowed to stir for $5 \mathrm{~min}$ at $22{ }^{\circ} \mathrm{C}$. Imine $\mathbf{2 h}(80 \mathrm{mg}, 0.4 \mathrm{mmol})$ was added immediately followed by $33 \mu \mathrm{L} i$-PrOH $(0.45 \mathrm{mmol})$. The test tube was capped with a septum, and allowed to stir in a cold room at $4{ }^{\circ} \mathrm{C}$ for $5 \mathrm{~min}$. Enol ether 3a $(160 \mu \mathrm{L}, 0.80 \mathrm{mmol})$ was added and the reaction mixture was allowed to stir at $4{ }^{\circ} \mathrm{C}$ for $16 \mathrm{~h}$. The reaction was quenched upon addition of $2 \mathrm{~mL}$ of $10 \%$ aqueous $\mathrm{HCl}$ followed by vigorous stirring for $5 \mathrm{~min} . \mathrm{CH}_{2} \mathrm{Cl}_{2}(5 \mathrm{~mL})$ was added and the mixture was allowed to stir vigorously for $1 \mathrm{~min}$. The layers were allowed to separate, and the bottom layer $\left(\mathrm{CH}_{2} \mathrm{Cl}_{2}\right)$ was removed with a pipette and placed into a round-bottom flask. The aqueous layer was washed with $2 \times 5 \mathrm{~mL}$ portions of $\mathrm{CH}_{2} \mathrm{Cl}_{2}$ and separated as stated above. The combined organic layers were concentrated (without drying) and purified by silica gel chromatography $\left(4: 1\right.$ hexanes: $\left.\mathrm{Et}_{2} \mathrm{O}\right)$ to deliver $108 \mathrm{mg}$ $(0.33 \mathrm{mmol}, 84 \%)$ of the desired product $4 \mathrm{ha}$ as a clear colorless oil. IR (neat, $\mathrm{NaCl})$ : 3402 (w), 1690 (s), 1608 (s), 1513 (s), 1457 (m), 1249 (m), 1224 (m), 1029 (m), 739 (s). ${ }^{1} \mathrm{H} \mathrm{NMR}\left(\mathrm{CDCl}_{3}, 400 \mathrm{MHz}\right): \delta 7.95(2 \mathrm{H}, \mathrm{d}, J=7.5 \mathrm{~Hz}), 7.58-7.32(4 \mathrm{H}, \mathrm{m}), 6.87-6.68$ $(4 \mathrm{H}, \mathrm{m}), 6.28-6.23(2 \mathrm{H}, \mathrm{m}), 5.30(1 \mathrm{H}$, apparent triplet, $J=6.4 \mathrm{~Hz}), 4.86(1 \mathrm{H}, \mathrm{br}), 3.84$ $(3 \mathrm{H}, \mathrm{s}), 3.61(2 \mathrm{H}, \mathrm{ddd}, J=16.7,6.6,6.0 \mathrm{~Hz}) .{ }^{13} \mathrm{C} \mathrm{NMR}\left(\mathrm{CDCl}_{3}, 100 \mathrm{MHz}\right): \delta 197.8$, $155.1,147.3,141.7,136.9,136.5,133.3,128.7,128.2,121.3,117.5,111.3,110.4,109.8$, 106.5, 55.6, 48.3, 42.9. HRMS (ES) Calcd for $\mathrm{C}_{20} \mathrm{H}_{19} \mathrm{NO}_{3} \mathrm{Na}$ : 344.1259; Found: 344.1263. $[\alpha]_{\mathrm{D}}{ }^{20}=+18.1^{\circ}\left(c=3.77, \mathrm{CHCl}_{3}\right)$ for a $84 \%$ ee sample.

The optical purity of $\mathbf{4 h}$ was established by chiral HPLC analysis (OD column, 9/1 hexanes/ $i$-PrOH eluent, $1 \mathrm{~mL} / \mathrm{min}$ and a lamp setting of $254 \mathrm{~nm}$ ); chromatograms are shown below. 

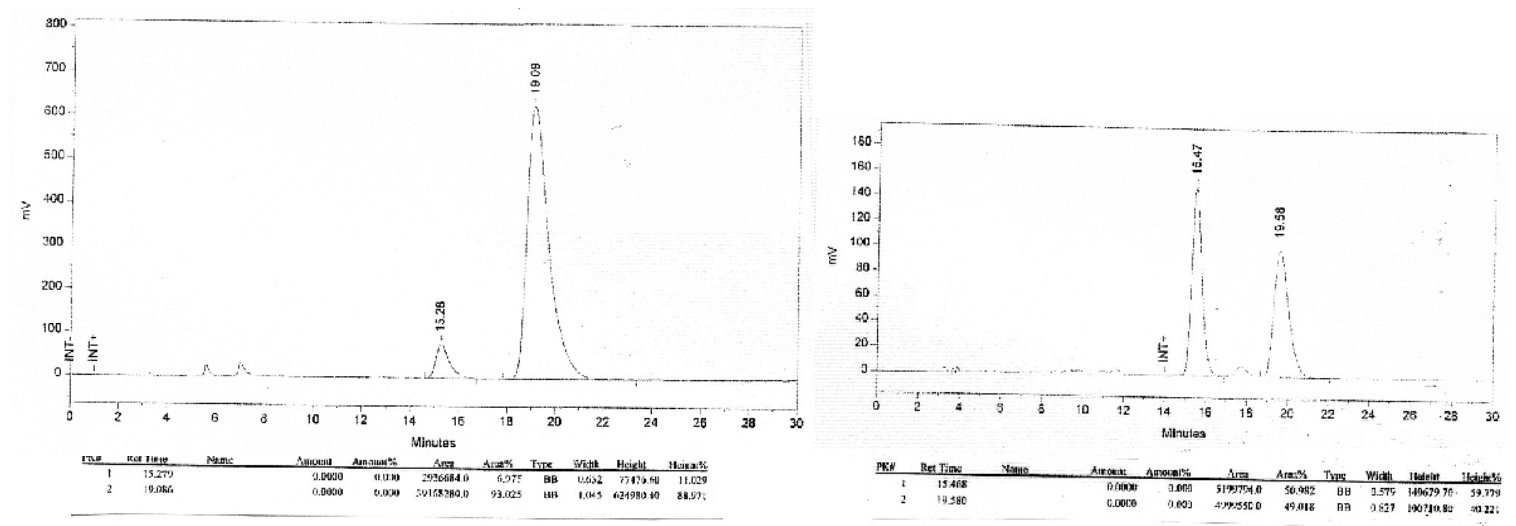

(+)-4-Furan-2-yl-4-(2-methoxyphenylamino)-butan-2-one (4hb); A modified procedure was used. Ligand $1(6.0 \mathrm{mg}, 12 \mu \mathrm{mol})$ and AgOAc $(2.0 \mathrm{mg}, 12 \mu \mathrm{mol})$ were

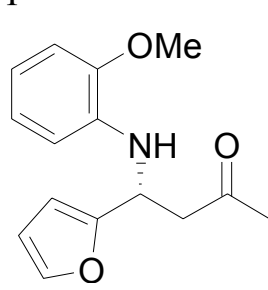
weighed into a $16 \times 150 \mathrm{~mm}$ test tube. The contents were dissolved in $0.4 \mathrm{~mL}$ of THF and allowed to stir for $5 \mathrm{~min}$ at $22^{\circ} \mathrm{C}$. Imine $\mathbf{2 h}(80 \mathrm{mg}$, $0.4 \mathrm{mmol}$ ) was added immediately followed by $33 \mu \mathrm{L} i$-PrOH $(0.45 \mathrm{mmol})$. The test tube was capped with a septum, and allowed to stir in a cold room at $4{ }^{\circ} \mathrm{C}$ for $5 \mathrm{~min}$. Enol ether $\mathbf{3 b}(130 \mu \mathrm{L}, 0.80$ mmol) was added and the reaction mixture was allowed to stir at $4{ }^{\circ} \mathrm{C}$ for $16 \mathrm{~h}$. The reaction was quenched upon addition of $2 \mathrm{~mL}$ of $10 \%$ aqueous $\mathrm{HCl}$ followed by vigorous stirring for $5 \mathrm{~min}$. $\mathrm{CH}_{2} \mathrm{Cl}_{2}(5 \mathrm{~mL})$ was added and the mixture was allowed to stir vigorously for $1 \mathrm{~min}$. The layers were allowed to separate, and the bottom layer $\left(\mathrm{CH}_{2} \mathrm{Cl}_{2}\right)$ was removed with a pipette and placed into a round-bottom flask. The aqueous layer was washed with $2 \times 5 \mathrm{~mL}$ portions of $\mathrm{CH}_{2} \mathrm{Cl}_{2}$ and separated as stated above. The combined organic layers were concentrated (without drying) and purified by silica gel chromatography $\left(4: 2\right.$ hexanes: $\left.\mathrm{Et}_{2} \mathrm{O}\right)$ to deliver $81 \mathrm{mg}(0.31 \mathrm{mmol}, 78 \%)$ of the desired product $\mathbf{4 h b}$ as a clear colorless oil. IR (neat, $\mathrm{NaCl}$ ): 3402 (m), 2941 (w), 1713 (s), 1601 (s), 1514 (s), 1458 (s), 1365 (m), 1252 (s), 1228 (s), 1128 (s), 1034 (s), 742 (s). ${ }^{1} \mathrm{H} \mathrm{NMR}\left(\mathrm{CDCl}_{3}, 400 \mathrm{MHz}\right): \delta 7.32(1 \mathrm{H}, \mathrm{s}), 6.85-6.68(4 \mathrm{H}, \mathrm{m}), 6.27(1 \mathrm{H}, \mathrm{dd}, J=3.2,2.0$ $\mathrm{Hz}), 6.19(1 \mathrm{H}, \mathrm{d}, J=3.2 \mathrm{~Hz}), 5.06(1 \mathrm{H}$, apparent triplet, $J=6.4), 4.74(1 \mathrm{H}, \mathrm{s}), 3.84(3 \mathrm{H}$, s), $3.04(2 \mathrm{H}, \mathrm{d}, J=6.4 \mathrm{~Hz}), 2.15(3 \mathrm{H}, \mathrm{s}) .{ }^{13} \mathrm{C} \mathrm{NMR}\left(\mathrm{CDCl}_{3}, 100 \mathrm{MHz}\right): \delta 206.5,154.9$, 147.3, 141.8, 136.3, 121.3, 117.6, 111.3, 110.4, 109.9, 106.4, 55.6, 48.0, 47.8, 30.7. HRMS (ES) Calcd for $\mathrm{C}_{15} \mathrm{H}_{17} \mathrm{NO}_{3} \mathrm{Na}$ : 282.1105; Found: 282.1106. $[\alpha]_{\mathrm{D}}{ }^{20}=+44.5^{\circ}(c=$ $2.10, \mathrm{CHCl}_{3}$ ) for a $88 \%$ ee sample.

The optical purity of $\mathbf{4 h b}$ was established by chiral HPLC analysis (OD column, $8 / 2$ hexanes/ $i$-PrOH eluent, $1 \mathrm{~mL} / \mathrm{min}$ and a lamp setting of $254 \mathrm{~nm}$ ); chromatograms are shown below. 

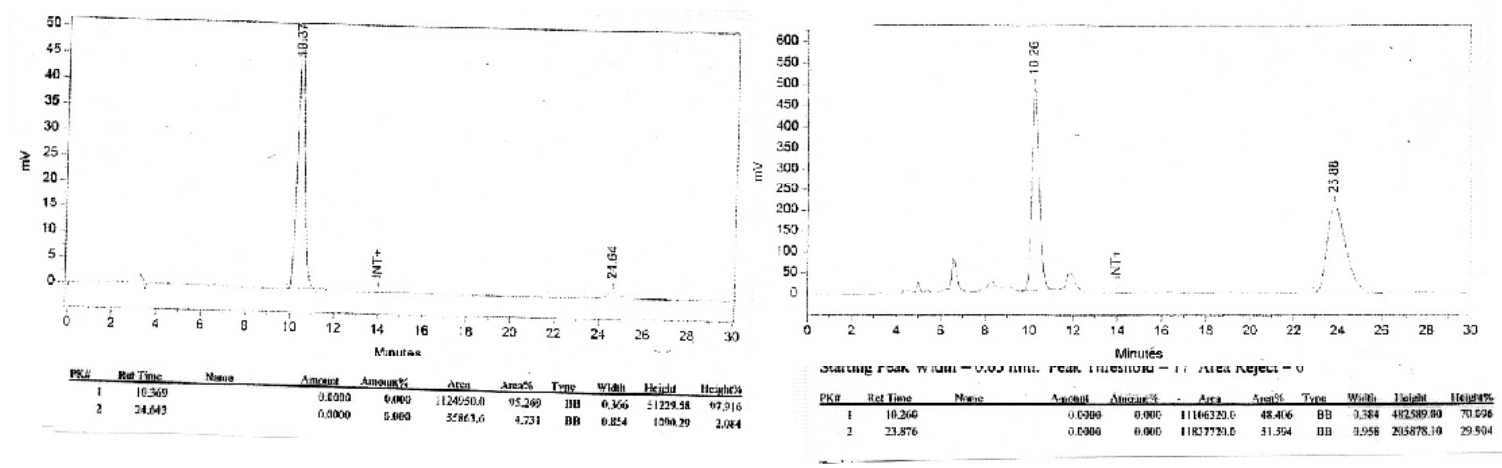

(+)-3-(2-Methoxyphenylamino)-1,5-diphenylpent-4-en-1-one (4ia); The representative procedure was followed. The crude product was purified by silica gel chromatography $\mathrm{OMe}$ (4:1 hexanes: $\left.\mathrm{Et}_{2} \mathrm{O}\right)$ to deliver $218 \mathrm{mg}(0.6 \mathrm{mmol}, 51 \%)$ of the desired product 4ia as a white solid. IR (neat, $\mathrm{NaCl}$ ): 3408 (w), $\mathrm{NH} \mathrm{O}$ 1683 (s), 1602 (s), 1513 (s), 1451 (s), 1224 (s), 1029 (m), 966 (m), $739(\mathrm{~s}), 689(\mathrm{~s}) .{ }^{1} \mathrm{H}$ NMR $\left(\mathrm{CDCl}_{3}, 400 \mathrm{MHz}\right): \delta 7.96(2 \mathrm{H}$, dd, $J=7.1,1.3 \mathrm{~Hz}), 7.58-7.16(8 \mathrm{H}, \mathrm{m}), 6.85-6.61(5 \mathrm{H}, \mathrm{m}), 6.31$ $(1 \mathrm{H}, \mathrm{dd}, J=15.9,6.0 \mathrm{~Hz}), 4.76-4.71(2 \mathrm{H}, \mathrm{m}), 3.85(3 \mathrm{H}, \mathrm{s}), 3.42$ ( $2 \mathrm{H}$, ddd, $J=16.3,6.6,5.7 \mathrm{~Hz}) .{ }^{13} \mathrm{C} \mathrm{NMR}\left(\mathrm{CDCl}_{3}, 100 \mathrm{MHz}\right)$ : $\delta$ 198.2, 147.3, 137.1, 136.9, 133.4, 130.7, 128.8, 128.6, 128.3, 127.6, 126.6, 125.4, 124.7, 121.4, 117.3, 111.5, 109.8, 55.6, 52.0, 44.5. HRMS (ES) Calcd for $\mathrm{C}_{24} \mathrm{H}_{23} \mathrm{NO}_{2} \mathrm{Na}$ : 380.1628; Found: 380.1626. Anal Calcd for $\mathrm{C}_{24} \mathrm{H}_{23} \mathrm{NO}_{2}$ : C, 80.64, H, 6.49; Found: $\mathrm{C}, 80.58, \mathrm{H}, 6.50 .[\alpha]_{\mathrm{D}}{ }^{20}=+1.4^{\circ}\left(c=0.97, \mathrm{CHCl}_{3}\right)$ for a $90 \% e e$ sample.

The optical purity of 4 ia was established by chiral HPLC analysis (OD column, $8 / 2$ hexanes/ $i$-PrOH eluent, $1 \mathrm{~mL} / \mathrm{min}$ and a lamp setting of $254 \mathrm{~nm}$ ); chromatograms are shown below.
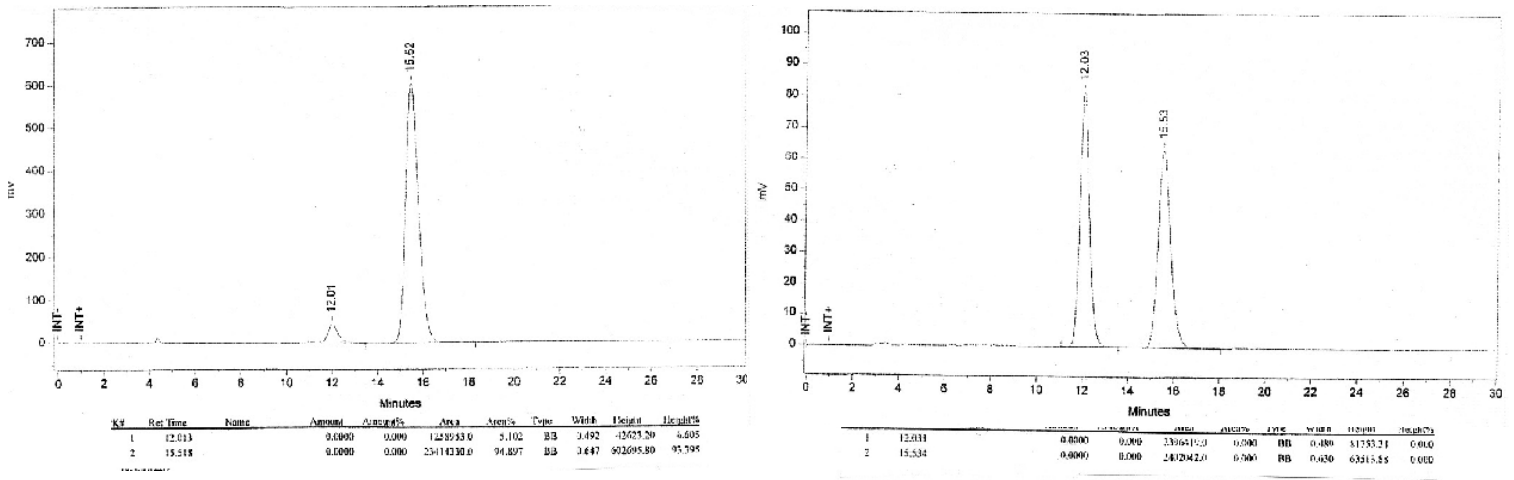

(+)-4-(2-Methoxyphenylamino)-6-phenylhex-5-en-2-one (4ib); The representative procedure was followed. The crude product was purified by silica gel $\mathrm{OMe}$ chromatography (4:1 hexanes:EtOAc) to deliver $273 \mathrm{mg}(0.92$ mmol, 77\%) of the desired product 4ib as a clear colorless oil. IR $\mathrm{NH} \mathrm{O} \quad$ (neat, $\mathrm{NaCl}$ ): 3408 (w), 1709 (s), 1595 (s), 1513 (s), 1457 (m), 1218 (s), 1029 (m), $966(\mathrm{~m}), 746$ (s). ${ }^{1} \mathrm{H}$ NMR $\left(\mathrm{CDCl}_{3}, 400 \mathrm{MHz}\right): \delta 7.33-$ $7.17(5 \mathrm{H}, \mathrm{m}), 6.84-6.55(5 \mathrm{H}, \mathrm{m}), 6.20(1 \mathrm{H}, \mathrm{dd}, J=16.0,6.0 \mathrm{~Hz})$, 
4.60-4.51 (2H, m), $3.85(3 \mathrm{H}, \mathrm{s}), 2.86(2 \mathrm{H}, \mathrm{ddd}, J=16.1,6.8,6.6 \mathrm{~Hz}), 2.18(3 \mathrm{H}, \mathrm{s}) .{ }^{13} \mathrm{C}$ NMR $\left(\mathrm{CDCl}_{3}, 100 \mathrm{MHz}\right): \delta 206.9,147.2,136.8,136.7,130.8,130.5,128.6,127.7,126.6$, 121.4, 117.3, 111.4, 109.8, 55.6, 51.7, 49.5, 30.9. HRMS (ES) Calcd for $\mathrm{C}_{19} \mathrm{H}_{21} \mathrm{NO}_{2} \mathrm{Na}$ : 318.1471; Found: $318.1470 .[\alpha]_{\mathrm{D}}{ }^{20}=+31.9^{\circ}\left(c=0.446, \mathrm{CHCl}_{3}\right)$ for a $89 \%$ ee sample.

The optical purity of 4ib was established by chiral HPLC analysis (OD column, $7 / 3$ hexanes/ $i-\mathrm{PrOH}$ eluent, $1 \mathrm{~mL} / \mathrm{min}$ and a lamp setting of $254 \mathrm{~nm}$ ); chromatograms are shown below.
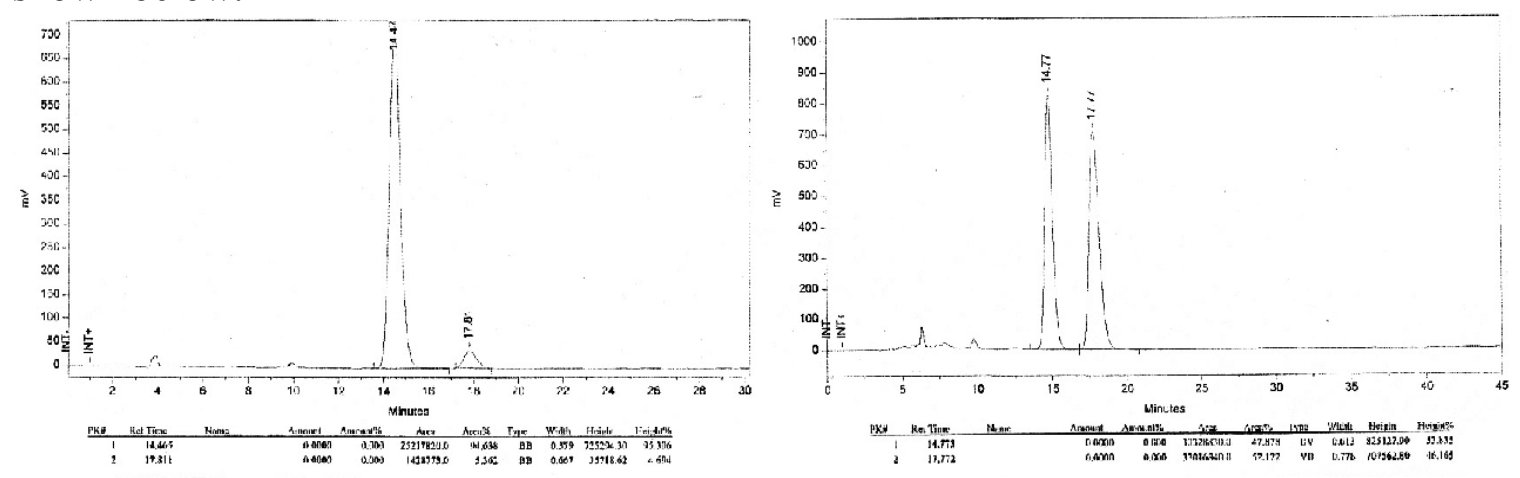

(+)-5-(4-Methoxyphenyl)-3-(2-methoxyphenylamino)-1-phenylpent-4-en-1-one (4ja); A modified procedure was used. Ligand $1(18 \mathrm{mg}, 36 \mu \mathrm{mol})$ and AgOAc $(6.0 \mathrm{mg}, 36$ $\mathrm{OMe}$ $\mu \mathrm{mol})$ were weighed into a $16 \times 150 \mathrm{~mm}$ test tube. The contents were dissolved in $1 \mathrm{~mL}$ of toluene and allowed $\mathrm{NH} \mathrm{O}$ to stir for $5 \mathrm{~min}$ at $22^{\circ} \mathrm{C}$. Imine $\mathbf{2 j}$ ( $\left.320 \mathrm{mg}, 1.20 \mathrm{mmol}\right)$ was added immediately followed by $100 \mu \mathrm{L} i-\mathrm{PrOH}(1.30$ $\mathrm{mmol})$. The test tube was capped with a septum, and allowed to stir at $22^{\circ} \mathrm{C}$ for $5 \mathrm{~min}$. Enol ether $3 \mathrm{a}(0.5 \mathrm{~mL}$, $2.4 \mathrm{mmol}$ ) was added and the reaction mixture was allowed to stir at $22{ }^{\circ} \mathrm{C}$ for $16 \mathrm{~h}$. The reaction was quenched upon addition of $2 \mathrm{~mL}$ of $10 \%$ aqueous $\mathrm{HCl}$ followed by vigorous stirring for 5 min. $\mathrm{CH}_{2} \mathrm{Cl}_{2}(5 \mathrm{~mL})$ was added and the mixture was allowed to stir vigorously for 1 $\mathrm{min}$. The layers were allowed to separate, and the bottom layer $\left(\mathrm{CH}_{2} \mathrm{Cl}_{2}\right)$ was removed with a pipette and placed into a round-bottom flask. The aqueous layer was washed with $2 \times 5 \mathrm{~mL}$ portions of $\mathrm{CH}_{2} \mathrm{Cl}_{2}$ and separated as stated above. The combined organic layers were concentrated (without drying) and purified by silica gel chromatography (4:1 hexanes: $\left.\mathrm{Et}_{2} \mathrm{O}\right)$ to deliver $343 \mathrm{mg}(0.89 \mathrm{mmol}, 74 \%)$ of the desired product $\mathbf{4 j a}$ as a white solid. IR (neat, $\mathrm{NaCl}$ ): 3408 (w), 1677 (m), $1602(\mathrm{~m}), 1507$ (s), 1457 (m), 1249 (s), 1218 (m), $1174(\mathrm{~m}), 1029(\mathrm{~m}), 733(\mathrm{~m}) .{ }^{1} \mathrm{H}$ NMR $\left(\mathrm{CDCl}_{3}, 400 \mathrm{MHz}\right): \delta 7.95(2 \mathrm{H}, \mathrm{d}, J=7.1$ $\mathrm{Hz}), 7.57-7.22(5 \mathrm{H}, \mathrm{m}), 6.84-6.55(7 \mathrm{H}, \mathrm{m}), 6.16(1 \mathrm{H}, \mathrm{dd}, J=16.0,6.0 \mathrm{~Hz}), 4.70-4.67(2 \mathrm{H}$, $\mathrm{m}), 3.84(3 \mathrm{H}, \mathrm{s}), 3.77(3 \mathrm{H}, \mathrm{s}), 3.40(2 \mathrm{H}, \mathrm{ddd}, J=15.9,6.6,5.5 \mathrm{~Hz}){ }^{13} \mathrm{C} \mathrm{NMR}\left(\mathrm{CDCl}_{3}\right.$, $100 \mathrm{MHz}): \delta 198.3,159.3,147.2,137.2,136.8,133.4,130.2,129.7,128.8,128.5,128.3$, 127.7, 121.4, 117.2, 114.0, 111.5, 109.7, 55.6, 55.4, 52.0, 44.6. HRMS (ES) Calcd for $\mathrm{C}_{25} \mathrm{H}_{25} \mathrm{NO}_{3} \mathrm{Na}$ : 410.1726; Found: $410.1726 .[\alpha]_{\mathrm{D}}{ }^{20}=+10.5^{\circ}\left(c=0.740, \mathrm{CHCl}_{3}\right)$ for a $96 \%$ ee sample.

The optical purity of $\mathbf{4 j a}$ was established by chiral HPLC analysis (OD column, $8 / 2$ hexanes/ $i$-PrOH eluent, $1 \mathrm{~mL} / \mathrm{min}$ and a lamp setting of $254 \mathrm{~nm}$ ); chromatograms are shown below. 

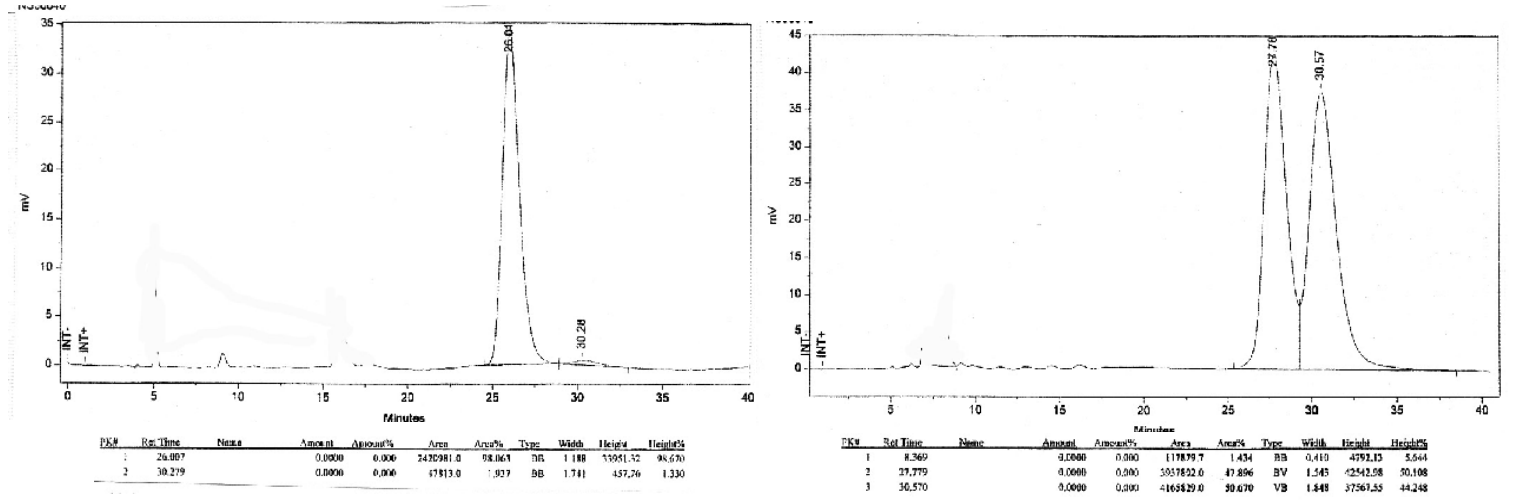

(+)-6-(4-Methoxyphenyl)-4-(2-methoxyphenylamino)-hex-5-en-2-one $\quad(4 \mathrm{jb}) ; \quad$ A modified procedure was used. Ligand $1(10 \mathrm{mg}, 20 \mu \mathrm{mol})$ and AgOAc $(3.0 \mathrm{mg}, 20 \mu \mathrm{mol})$

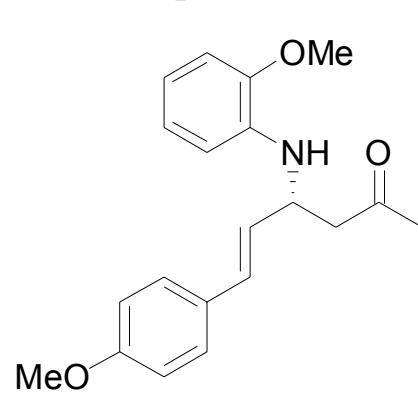
were weighed into a $16 \times 150 \mathrm{~mm}$ test tube. The contents were dissolved in $0.4 \mathrm{~mL}$ of toluene and allowed to stir for $5 \mathrm{~min}$ at $22{ }^{\circ} \mathrm{C}$. Imine $2 \mathbf{j}$ ( $\left.110 \mathrm{mg}, 0.40 \mathrm{mmol}\right)$ was added immediately followed by $33 \mu \mathrm{L} i$-PrOH $(0.45 \mathrm{mmol})$. The test tube was capped with a septum, and allowed to stir at $22{ }^{\circ} \mathrm{C}$ for $5 \mathrm{~min}$. Enol ether $3 \mathbf{b}(130 \mu \mathrm{L}, 0.80 \mathrm{mmol})$ was added and the reaction mixture was allowed to stir at $22{ }^{\circ} \mathrm{C}$ for $16 \mathrm{~h}$. The reaction was quenched upon addition of $2 \mathrm{~mL}$ of $10 \%$ aqueous $\mathrm{HCl}$ followed by vigorous stirring for $5 \mathrm{~min} . \mathrm{CH}_{2} \mathrm{Cl}_{2}(5 \mathrm{~mL})$ was added and the mixture was allowed to stir vigorously for $1 \mathrm{~min}$. The layers were allowed to separate, and the bottom layer $\left(\mathrm{CH}_{2} \mathrm{Cl}_{2}\right)$ was removed with a pipette and placed into a round-bottom flask. The aqueous layer was washed with $2 \times 5 \mathrm{~mL}$ portions of $\mathrm{CH}_{2} \mathrm{Cl}_{2}$ and separated as stated above. The combined organic layers were concentrated (without drying) and purified by silica gel chromatography ( $4: 1$ hexanes:EtOAc) to deliver $62 \mathrm{mg}$ $(0.2 \mathrm{mmol}, 47 \%)$ of the desired product $4 \mathbf{j b}$ as a white solid. IR (neat, $\mathrm{NaCl}): 3404(\mathrm{w})$, $1711(\mathrm{~m}), 1605$ (s), $1512(\mathrm{~s}), 1456(\mathrm{~m}), 1252(\mathrm{~s}), 1177$ (m), $1022(\mathrm{~m}), 737$ (m). ${ }^{1} \mathrm{H}$ NMR $\left(\mathrm{CDCl}_{3}, 400 \mathrm{MHz}\right): \delta 7.25(2 \mathrm{H}, \mathrm{dd}, J=7.7,0.4 \mathrm{~Hz}), 6.84-6.50(7 \mathrm{H}, \mathrm{m}), 6.05(1 \mathrm{H}, \mathrm{dd}, J=$ $15.9,6.2 \mathrm{~Hz}), 4.59-4.47(2 \mathrm{H}, \mathrm{m}), 3.84(3 \mathrm{H}, \mathrm{s}), 3.77(3 \mathrm{H}, \mathrm{s}), 2.84(2 \mathrm{H}, \mathrm{ddd}, J=16.1,6.6$, $6.0 \mathrm{~Hz}), 2.17(3 \mathrm{H}, \mathrm{s}) .{ }^{13} \mathrm{C} \mathrm{NMR}\left(\mathrm{CDCl}_{3}, 100 \mathrm{MHz}\right): \delta 207.0,159.3,147.2,136.8,130.2$, 129.6, 128.2, 127.7, 121.4, 117.2, 114.1, 111.4, 109.7, 55.6, 55.4, 51.8, 49.6, 30.9. HRMS (ES) Calcd for $\mathrm{C}_{20} \mathrm{H}_{23} \mathrm{NO}_{3} \mathrm{Na}$ : 348.1580; Found: 348.1576. $[\alpha]_{\mathrm{D}}{ }^{20}=+27.4^{\circ}(c=$ $0.667, \mathrm{CHCl}_{3}$ ) for a $90 \%$ ee sample.

The optical purity of $\mathbf{4 j b}$ was established by chiral HPLC analysis (OD column, $9 / 1$ hexanes/ $i$ - $\mathrm{PrOH}$ eluent, $1 \mathrm{~mL} / \mathrm{min}$ and a lamp setting of $254 \mathrm{~nm}$ ); chromatograms are shown below. 

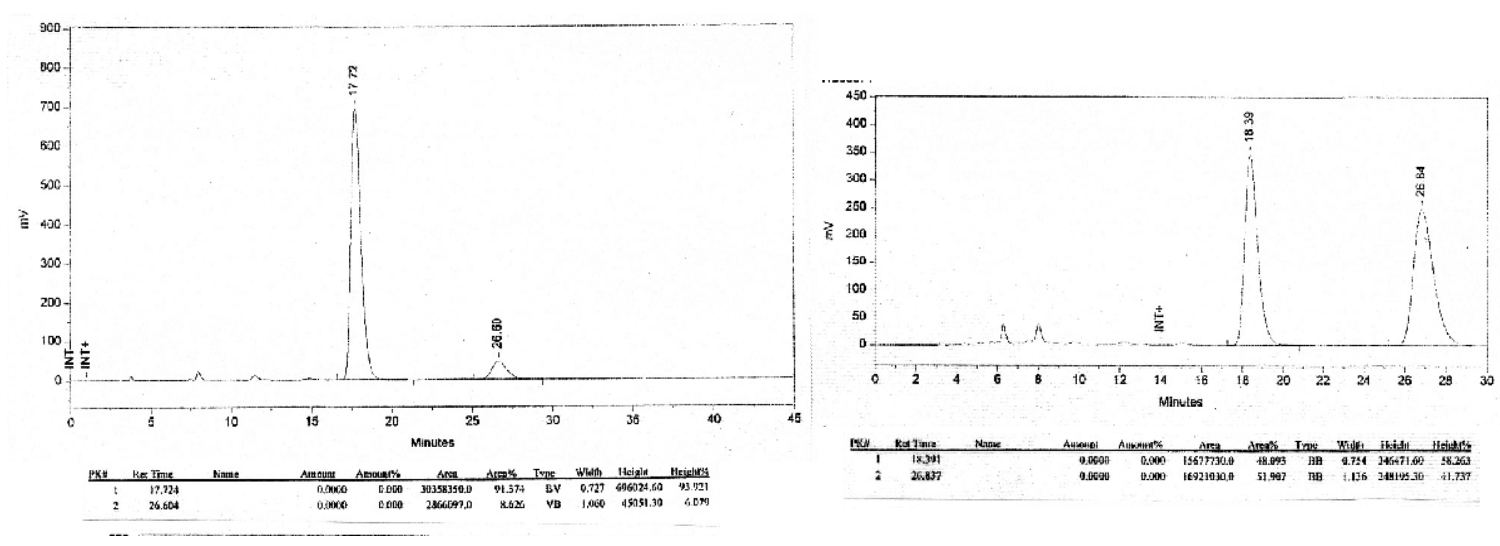

(+)-3-(2-Methoxyphenylamino)-5-(4-nitrophenyl)-1-phenylpent-4-en-1-one (4ka); A modified procedure was used. Ligand 1 (6.0 mg, $12 \mu \mathrm{mol})$ and AgOAc (2.0 mg, 12 OMe $\mu \mathrm{mol})$ were weighed into a $16 \times 150 \mathrm{~mm}$ test tube. The contents were dissolved in $0.4 \mathrm{~mL}$ of $\mathrm{THF}$ and allowed to stir for $5 \mathrm{~min}$ at $22^{\circ} \mathrm{C}$. Imine $2 \mathbf{k}(115 \mathrm{mg}, 0.40 \mathrm{mmol})$ was added immediately followed by $33 \mu \mathrm{L} i$-PrOH $(0.45$ mmol). The test tube was capped with a septum, and allowed to stir in a cold bath at $-5^{\circ} \mathrm{C}$ for $5 \mathrm{~min}$. Enol ether 3a $(160 \mu \mathrm{L}, 0.80 \mathrm{mmol})$ was added and the reaction mixture was allowed to stir at $-5{ }^{\circ} \mathrm{C}$ for $16 \mathrm{~h}$. The reaction was quenched upon addition of $2 \mathrm{~mL}$ of $10 \%$ aqueous $\mathrm{HCl}$ followed by vigorous stirring for $5 \mathrm{~min} . \mathrm{CH}_{2} \mathrm{Cl}_{2}(5 \mathrm{~mL})$ was added and the mixture was allowed to stir vigorously for $1 \mathrm{~min}$. The layers were allowed to separate, and the bottom layer $\left(\mathrm{CH}_{2} \mathrm{Cl}_{2}\right)$ was removed with a pipette and placed into a round-bottom flask. The aqueous layer was washed with $2 \times 5 \mathrm{~mL}$ portions of $\mathrm{CH}_{2} \mathrm{Cl}_{2}$ and separated as stated above. The combined organic layers were concentrated (without drying) and purified by silica gel chromatography $\left(4: 1\right.$ hexanes: $\left.\mathrm{Et}_{2} \mathrm{O}\right)$ to deliver $160 \mathrm{mg}(0.40 \mathrm{mmol}, 99 \%)$ of the desired product 4ka as a orange solid. IR (neat, $\mathrm{NaCl}$ ): 3402 (w), 1683 (m), 1595 (s), 1513 (s), 1457 (w), 1344 (s), 1224 (m), 746 (m). ${ }^{1} \mathrm{H}$ NMR (CDCl $\left.3,400 \mathrm{MHz}\right): \delta 8.11$ $(2 \mathrm{H}, \mathrm{d}, J=8.8 \mathrm{~Hz}), 7.97(2 \mathrm{H}, \mathrm{d}, J=7.1 \mathrm{~Hz}), 7.61-7.41(4 \mathrm{H}, \mathrm{m}), 6.87-6.68(5 \mathrm{H}, \mathrm{m}), 6.54$ $(2 \mathrm{H}, \mathrm{dd}, J=16.0,5.5 \mathrm{~Hz}) 4.81-4.77(2 \mathrm{H}, \mathrm{m}), 3.87(3 \mathrm{H}, \mathrm{s}), 3.47(2 \mathrm{H}, \mathrm{ddd}, J=16.8,6.8$, $5.5 \mathrm{~Hz}) .{ }^{13} \mathrm{C} \mathrm{NMR}\left(\mathrm{CDCl}_{3}, 100 \mathrm{MHz}\right): \delta 197.7,147.1,146.8,143.3,136.8,136.4,135.9$, $133.5,128.8,128.6,128.2,127.0,123.9,121.3,117.4,111.2,109.8,55.5,51.5,44.1$. HRMS (ES) Calcd for $\mathrm{C}_{24} \mathrm{H}_{22} \mathrm{~N}_{2} \mathrm{O}_{4} \mathrm{Na}$ : 425.1458; Found: 425.1477. Anal Calcd for $\mathrm{C}_{24} \mathrm{H}_{22} \mathrm{~N}_{2} \mathrm{O}_{4}$ : C, 71.63, H, 5.51; Found: C, 71.74, H, 5.54. $[\alpha]_{\mathrm{D}}{ }^{20}=+7.4^{\mathrm{o}}(c=2.29$, $\mathrm{CHCl}_{3}$ ) for a $92 \%$ ee sample.

The optical purity of $\mathbf{4 k a}$ was established by chiral HPLC analysis (OD column, $75 / 25$ hexanes/ $i$-PrOH eluent, $1 \mathrm{~mL} / \mathrm{min}$ and a lamp setting of $254 \mathrm{~nm}$ ); chromatograms are shown below. 

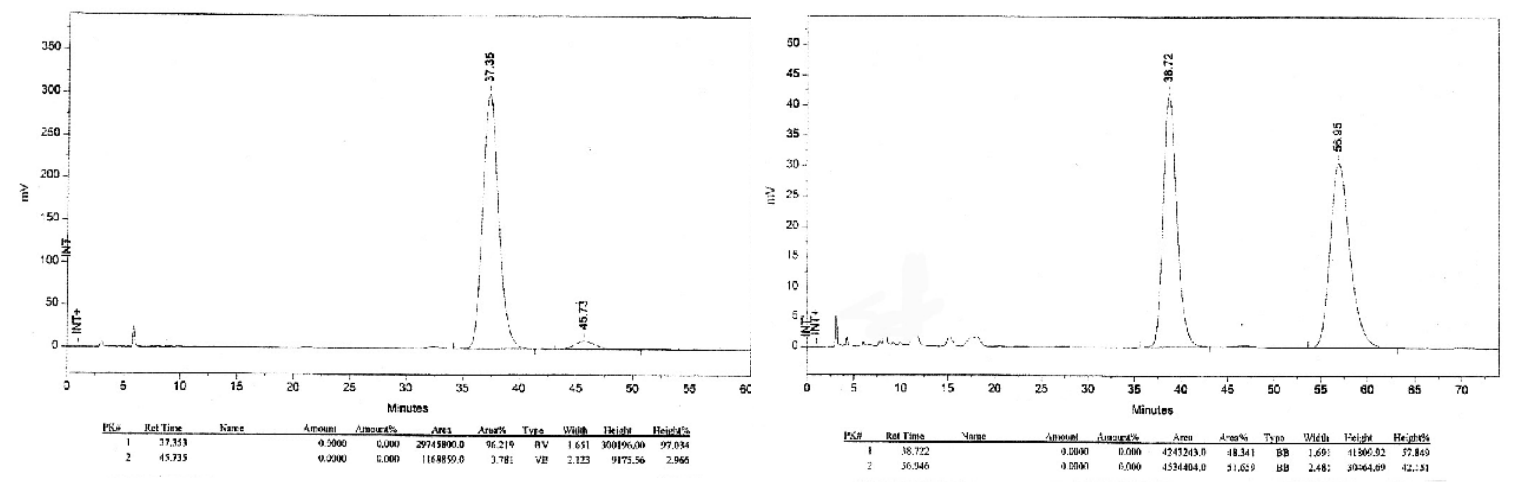

(+)-4-(2-Methoxyphenylamino)-6-(4-nitrophenyl)-hex-5-en-2-one (4kb); A modified procedure was used. Ligand $1(6.0 \mathrm{mg}, 12 \mu \mathrm{mol})$ and AgOAc $(2.0 \mathrm{mg}, 12 \mu \mathrm{mol})$ were OMe weighed into a $16 \times 150 \mathrm{~mm}$ test tube. The contents were dissolved in $0.4 \mathrm{~mL}$ of THF and allowed to stir for $5 \mathrm{~min}$ at 22 $\mathrm{NH} \quad \mathrm{O} \quad{ }^{\circ} \mathrm{C}$. Imine $2 \mathbf{k}(115 \mathrm{mg}, 0.40 \mathrm{mmol})$ was added immediately followed by $33 \mu \mathrm{L} i$-PrOH $(0.45 \mathrm{mmol})$. The test tube was capped with a septum, and allowed to stir in a cold bath at $-5{ }^{\circ} \mathrm{C}$ for $5 \mathrm{~min}$. Enol ether $\mathbf{3 b}(130 \mu \mathrm{L}, 0.80 \mathrm{mmol})$ was added and the reaction mixture was allowed to stir at $-5^{\circ} \mathrm{C}$ for $16 \mathrm{~h}$. The reaction was quenched upon addition of $2 \mathrm{~mL}$ of $10 \%$ aqueous $\mathrm{HCl}$ followed by vigorous stirring for $5 \mathrm{~min}$. $\mathrm{CH}_{2} \mathrm{Cl}_{2}(5 \mathrm{~mL})$ was added and the mixture was allowed to stir vigorously for $1 \mathrm{~min}$. The layers were allowed to separate, and the bottom layer $\left(\mathrm{CH}_{2} \mathrm{Cl}_{2}\right)$ was removed with a pipette and placed into a round-bottom flask. The aqueous layer was washed with $2 \times 5 \mathrm{~mL}$ portions of $\mathrm{CH}_{2} \mathrm{Cl}_{2}$ and separated as stated above. The combined organic layers were concentrated (without drying) and purified by silica gel chromatography $\left(4: 1\right.$ hexanes: $\left.\mathrm{Et}_{2} \mathrm{O}\right)$ to deliver $101 \mathrm{mg}(0.30 \mathrm{mmol}, 74 \%)$ of the desired product 4kb as a orange solid. IR (neat, $\mathrm{NaCl}$ ): $3402(\mathrm{w}), 1715(\mathrm{~m}), 1595(\mathrm{~m})$, 1513 (s), 1344 (s), 1224 (m), 1023 (w), 739 (m). ${ }^{1} \mathrm{H}$ NMR (CDCl $\left.3,400 \mathrm{MHz}\right): \delta 8.13$ $(2 \mathrm{H}, \mathrm{dd}, J=6.9,1.8 \mathrm{~Hz}), 7.44(2 \mathrm{H}, \mathrm{dd}, J=6.9,1.7 \mathrm{~Hz}), 6.86-6.63(5 \mathrm{H}, \mathrm{m}), 6.44(1 \mathrm{H}, \mathrm{dd}$, $J=15.9,5.7 \mathrm{~Hz}), 4.62-4.55(2 \mathrm{H}, \mathrm{m}), 3.87(3 \mathrm{H}, \mathrm{s}), 2.91(2 \mathrm{H}, \mathrm{ddd}, J=16.5,6.4,5.8 \mathrm{~Hz})$, $2.21(3 \mathrm{H}, \mathrm{s}) .{ }^{13} \mathrm{C}$ NMR $\left(\mathrm{CDCl}_{3}, 100 \mathrm{MHz}\right): \delta 206.4,147.1,147.0,143.3,136.4,135.6$, 128.7, 127.1, 124.0, 121.3, 117.6, 111.2, 109.8, 55.6, 51.4, 49.1, 30.8. HRMS (ES) Calcd for $\mathrm{C}_{19} \mathrm{H}_{20} \mathrm{~N}_{2} \mathrm{O}_{4} \mathrm{Na}$ : 363.1311; Found: 363.1321. Anal Calcd for $\mathrm{C}_{19} \mathrm{H}_{20} \mathrm{~N}_{2} \mathrm{O}_{4}$ : C, 67.05, H, 5.92; Found: $\mathrm{C}, 67.39, \mathrm{H}, 5.71 .[\alpha]_{\mathrm{D}}^{20}=+30.9^{\circ}\left(c=1.67, \mathrm{CHCl}_{3}\right)$ for a $90 \%$ ee sample.

The optical purity of $\mathbf{4 k b}$ was established by chiral HPLC analysis (OD column, $75 / 25$ hexanes / $i-\mathrm{PrOH}$ eluent, $1 \mathrm{~mL} / \mathrm{min}$ and a lamp setting of $254 \mathrm{~nm}$ ); chromatograms are shown below. 

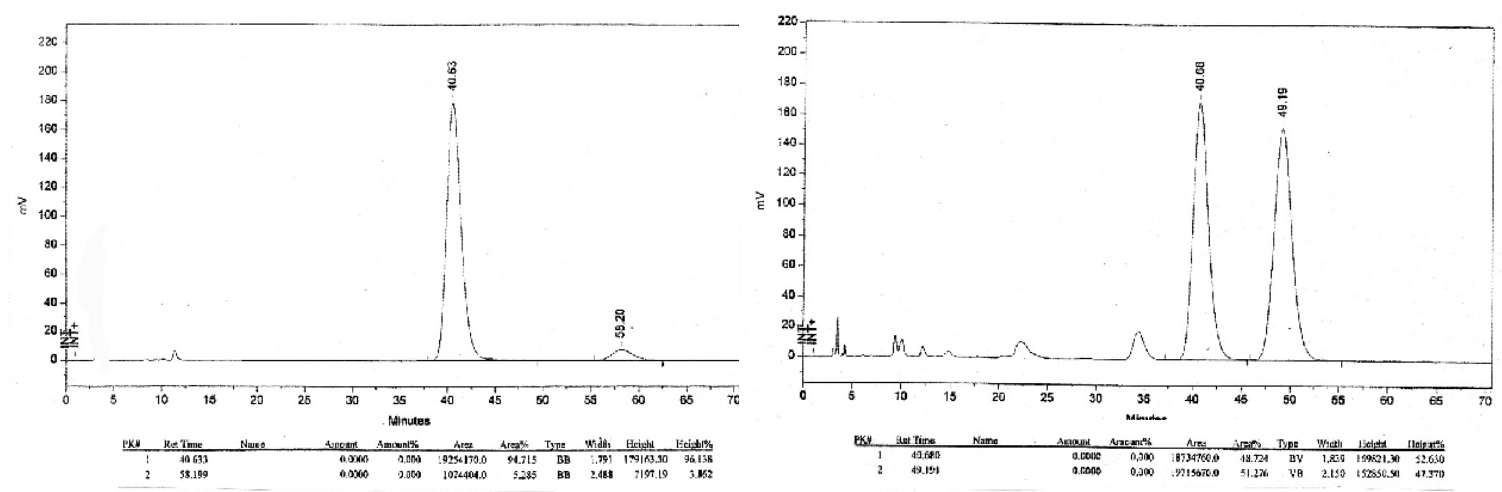

(+)-3-(2-Methoxyphenylamino)-1,5-diphenylpent-4-yn-1-one (4la); The representative procedure was followed. The crude product was purified by silica gel chromatography $\mathrm{OMe}$ (4:1 hexanes: $\left.\mathrm{Et}_{2} \mathrm{O}\right)$ to deliver $395 \mathrm{mg}(1.10 \mathrm{mmol}, 93 \%)$ of the desired product 4la as a white solid. IR (neat, $\mathrm{NaCl}$ ): 3389 (w), 3062 (w), 1690 (s), 1602 (s), 1513 (s), 1451 (s), 1249 (s), 1224 (s), 1123 (m), 1035 (m), 909 (m), 758 (s), 689 (s). ${ }^{1} \mathrm{H}$ NMR $\left(\mathrm{CDCl}_{3}, 400 \mathrm{MHz}\right): \delta 8.01(2 \mathrm{H}, \mathrm{d}, J=7.1 \mathrm{~Hz})$, 7.60-4.45 (3H, m), 7.32-7.21 (5H, m), 6.98-6.91 (2H, m), 6.82-6.74 $(2 \mathrm{H}, \mathrm{m}), 5.07(1 \mathrm{H}$, apparent triplet, $J=6.4 \mathrm{~Hz})$, $4.82(1 \mathrm{H}, \mathrm{br}), 3.84(3 \mathrm{H}, \mathrm{s}), 3.60(2 \mathrm{H}, \mathrm{ddd}, J=16.4,6.6,6.0$ $\mathrm{Hz}) .{ }^{13} \mathrm{C} \mathrm{NMR}\left(\mathrm{CDCl}_{3}, 100 \mathrm{MHz}\right): \delta$ 197.1, 147.7, 137.0, 136.1, 133.4, 131.8, 128.8, $128.3,128.2,127.6,122.9,121.3,118.1,112.1,109.9,89.3,83.3,55.6,44.3,42.5$. HRMS (ES) Calcd for $\mathrm{C}_{24} \mathrm{H}_{21} \mathrm{NO}_{2} \mathrm{Na}$ : 378.1472; Found: 378.1470 . $[\alpha]_{\mathrm{D}}{ }^{20}=+82.0^{\circ}(c=$ $0.62, \mathrm{CHCl}_{3}$ ) for a $92 \%$ ee sample.

The optical purity of 4la was established by chiral HPLC analysis (OD column, $7 / 3$ hexanes/ $i$-PrOH eluent, $1 \mathrm{~mL} / \mathrm{min}$ and a lamp setting of $254 \mathrm{~nm}$ ); chromatograms are shown below.
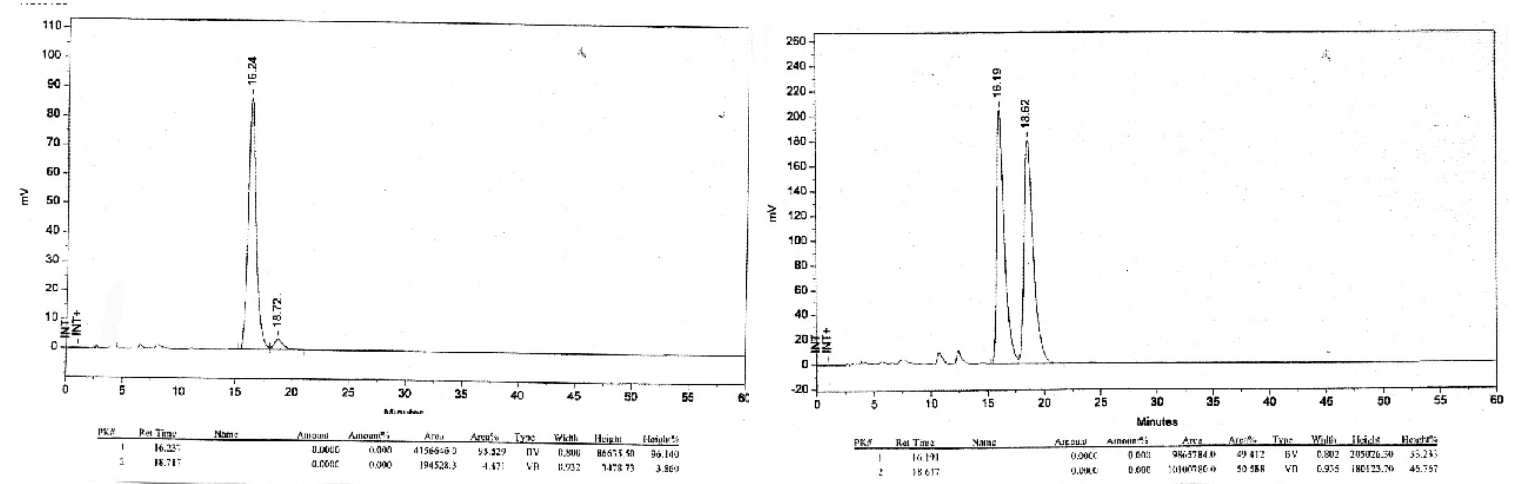

(+)-4-(2-Methoxyphenylamino)-6-phenylhex-5-yn-2-one (4lb); A modified procedure was used. Ligand $1(6.0 \mathrm{mg}, 12 \mu \mathrm{mol})$ and AgOAc $(2.0 \mathrm{mg}, 12$

$\mathrm{OMe}$ $\mu \mathrm{mol})$ were weighed into a $16 \times 150 \mathrm{~mm}$ test tube. The contents were dissolved in $0.4 \mathrm{~mL}$ of THF and allowed to stir for $5 \mathrm{~min}$ at $\mathrm{NH} \quad \mathrm{O}$ $22{ }^{\circ} \mathrm{C}$. Imine 21 (95 $\left.\mathrm{mg}, 0.4 \mathrm{mmol}\right)$ was added immediately followed by $33 \mu \mathrm{L} i$-PrOH $(0.45 \mathrm{mmol})$. The test tube was capped with a septum, and allowed to stir in a cold bath at $-5^{\circ} \mathrm{C}$ for $5 \mathrm{~min}$. 
Enol ether $\mathbf{3 b}(130 \mu \mathrm{L}, 0.80 \mathrm{mmol})$ was added and the reaction mixture was allowed to stir at $-5{ }^{\circ} \mathrm{C}$ for $16 \mathrm{~h}$. The reaction was quenched upon addition of $2 \mathrm{~mL}$ of $10 \%$ aqueous $\mathrm{HCl}$ followed by vigorous stirring for $5 \mathrm{~min}$. $\mathrm{CH}_{2} \mathrm{Cl}_{2}(5 \mathrm{~mL})$ was added and the mixture was allowed to stir vigorously for $1 \mathrm{~min}$. The layers were allowed to separate, and the bottom layer $\left(\mathrm{CH}_{2} \mathrm{Cl}_{2}\right)$ was removed with a pipette and placed into a round-bottom flask. The aqueous layer was washed with $2 \times 5 \mathrm{~mL}$ portions of $\mathrm{CH}_{2} \mathrm{Cl}_{2}$ and separated as stated above. The combined organic layers were concentrated (without drying) and purified by silica gel chromatography ( $4: 1$ hexanes:EtOAc) to deliver $107 \mathrm{mg}(0.37 \mathrm{mmol}, 91 \%$ yield) of the desired product 4lb as a light orange solid. IR (neat, NaCl): $3383(\mathrm{w}), 1715$ (m), $1602(\mathrm{~m}), 1507$ (s), $1457(\mathrm{~m}), 1243(\mathrm{~m}), 1224(\mathrm{~m}), 1123(\mathrm{~m}), 1029(\mathrm{~m}), 758(\mathrm{~m}), 739$ (m), $689(\mathrm{~m}) .{ }^{1} \mathrm{H}$ NMR $\left(\mathrm{CDCl}_{3}, 400 \mathrm{MHz}\right): \delta$ 7.35-7.22 (5H, m), 6.90-6.72 (4H, m), 4.82 $(1 \mathrm{H}$, apparent triplet, $J=6.4 \mathrm{~Hz}), 4.67(1 \mathrm{H}, \mathrm{br}), 3.83(3 \mathrm{H}, \mathrm{s}), 3.03(2 \mathrm{H}$, ddd, $J=16.3,6.4$, $6.2 \mathrm{~Hz}), 2.24(3 \mathrm{H}, \mathrm{s}) .{ }^{13} \mathrm{C} \mathrm{NMR}\left(\mathrm{CDCl}_{3}, 100 \mathrm{MHz}\right): \delta 205.8,147.7,136.0,131.9,128.3$, $128.3,122.9,121.3,118.3,112.2,109.9,89.0,83.2,55.6,49.1,42.3,31.0$. HRMS (ES) Calcd for $\mathrm{C}_{19} \mathrm{H}_{19} \mathrm{NO}_{2} \mathrm{Na}$ : 316.1309; Found: $316.1313 .[\alpha]_{\mathrm{D}}{ }^{20}=+101^{\circ}\left(c=1.12, \mathrm{CHCl}_{3}\right)$ for a $88 \%$ ee sample.

The optical purity of 4lb was established by chiral HPLC analysis (OD column, $75 / 25$ hexanes/ $i$-PrOH eluent, $1 \mathrm{~mL} / \mathrm{min}$ and a lamp setting of $254 \mathrm{~nm}$ ); chromatograms are shown below.
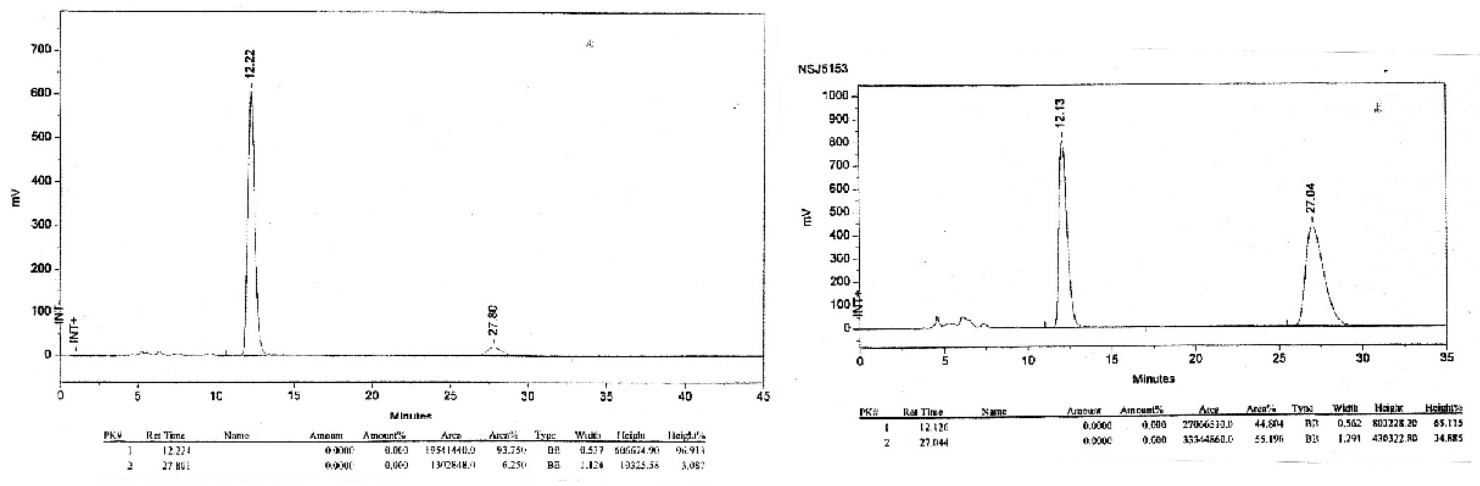

(+)-4-(2-Methoxyphenylamino)-tetradecan-2-one(7m); To a 16 x $150 \mathrm{~mm}$ test tube

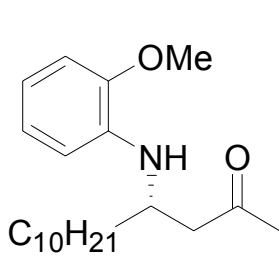
charged with $250 \mu \mathrm{L}(1.2 \mathrm{mmol})$ of undecilic aldehyde $(\mathbf{m})$ cooled to $5{ }^{\circ} \mathrm{C}$ was added $135 \mu \mathrm{L}(1.2 \mathrm{mmol})$ of $o$-anisidine. The solution was allowed to stir at that temperature for 5 min upon which time it turned cloudy. THF was then added $(1.0 \mathrm{~mL})$ and the solution was allowed to warm to $22{ }^{\circ} \mathrm{C}$ and ligand $1(31 \mathrm{mg}, 60 \mu \mathrm{mol})$ and $\mathrm{AgOAc}(10 \mathrm{mg}, 60$ $\mu \mathrm{mol})$ were added and the solution was allowed to stir at that temperature for $5 \mathrm{~min}$. The solution was then cooled to $4{ }^{\circ} \mathrm{C}$ in a cold room and enol ether $3 \mathbf{b}(400 \mu \mathrm{L}, 2.40 \mathrm{mmol})$ was added and the reaction mixture was allowed to stir at 4 ${ }^{\circ} \mathrm{C}$ for $16 \mathrm{~h}$. The reaction was quenched upon addition of $2 \mathrm{~mL}$ of $10 \%$ aqueous $\mathrm{HCl}$ followed by vigorous stirring for $5 \mathrm{~min}$. $\mathrm{CH}_{2} \mathrm{Cl}_{2}(5 \mathrm{~mL})$ was added and the mixture was allowed to stir vigorously for $1 \mathrm{~min}$. The layers were allowed to separate, and the bottom layer $\left(\mathrm{CH}_{2} \mathrm{Cl}_{2}\right)$ was removed with a pipette and placed into a round-bottom flask. The aqueous layer was washed with $2 \times 5 \mathrm{~mL}$ portions of $\mathrm{CH}_{2} \mathrm{Cl}_{2}$ and separated as stated 
above. The combined organic layers were concentrated (without drying) and purified by silica gel chromatography ( $4: 1$ hexanes: $\left.\mathrm{Et}_{2} \mathrm{O}\right)$ to deliver $240 \mathrm{mg}(0.72 \mathrm{mmol}, 60 \%)$ of the desired product $\mathbf{4 m}$ as a clear colorless oil. IR (neat, $\mathrm{NaCl}$ ): 3422 (w), 2917 (s), 2855 (s), $1710(\mathrm{~m}), 1597$ (m), $1512(\mathrm{~m}), 1455$ (m), 1353 (w), $1217(\mathrm{~m}), 1030(\mathrm{w}) .{ }^{1} \mathrm{H}$ NMR $\left(\mathrm{CDCl}_{3}, 400 \mathrm{MHz}\right): \delta 6.85(1 \mathrm{H}, \mathrm{ddd}, J=7.6,1.3,1.1 \mathrm{~Hz}), 6.77(1 \mathrm{H}, \mathrm{dd}, J=7.8,1.1 \mathrm{~Hz})$, 6.67-6.61 $(2 \mathrm{H}, \mathrm{m}), 4.18(1 \mathrm{H}, \mathrm{s}), 3.84(1 \mathrm{H}$, partially covered $), 3.83(3 \mathrm{H}, \mathrm{s}), 2.72(1 \mathrm{H}, \mathrm{dd}, J$ $=16.3,5.1 \mathrm{~Hz}), 2.57(1 \mathrm{H}, \mathrm{dd}, J=16.2,6.9 \mathrm{~Hz}), 2.14(3 \mathrm{H}, \mathrm{s}), 1.59-1.25(18 \mathrm{H}, \mathrm{m}), 0.88$ $(3 \mathrm{H}, \mathrm{t}, J=6.6 \mathrm{~Hz}) \cdot{ }^{13} \mathrm{C} \mathrm{NMR}\left(\mathrm{CDCl}_{3}, 100 \mathrm{MHz}\right): \delta 208.2,147.0,137.2,121.5,116.4$, 110.3, 109.8, 55.5, 49.4, 48.6, 35.4, 32.0, 31.0, 29.7, 29.7, 29.6, 29.4, 26.3, 22.8, 14.3. HRMS (ES) Calcd for $\mathrm{C}_{21} \mathrm{H}_{36} \mathrm{NO}_{2}$ : 334.2748 ; Found: 224.2746. $[\alpha]_{\mathrm{D}}{ }^{20}=+0.187^{\circ}(c=$ $2.14, \mathrm{CHCl}_{3}$ ) for a $92 \%$ ee sample.

The optical purity of $\mathbf{4 m}$ was established by chiral HPLC analysis (OD column, $95 / 5$ hexanes/ $i$-PrOH eluent, $1 \mathrm{~mL} / \mathrm{min}$ and a lamp setting of $254 \mathrm{~nm}$ ); chromatograms are shown below.
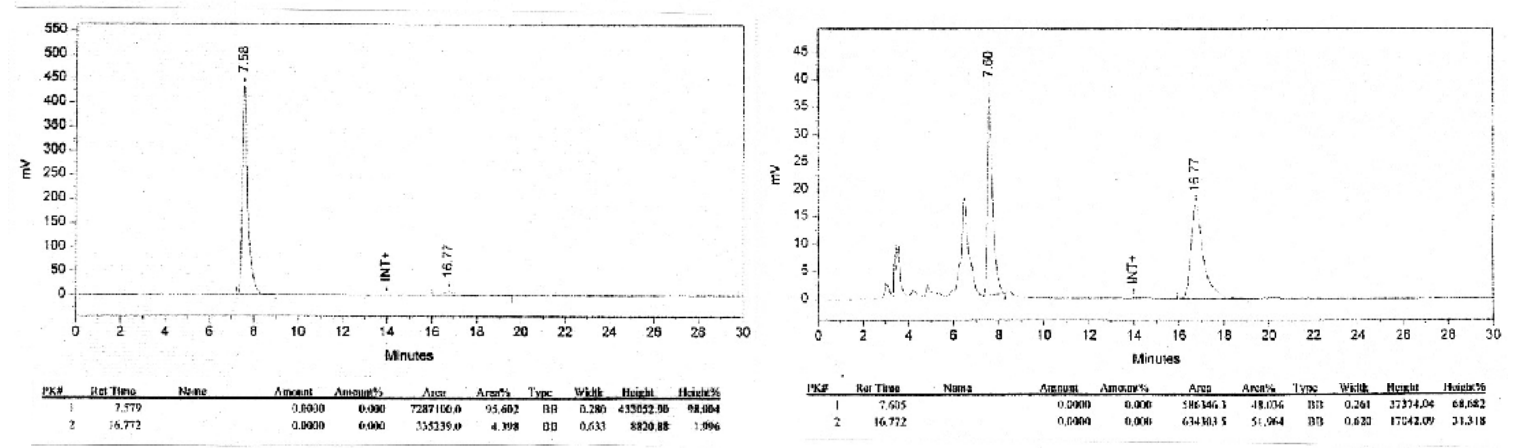

(+)-4-Cyclohexyl-4-(2-methoxyphenylamino)-butan-2-one (7n); In a 16 x $150 \mathrm{~mm}$ test tube charged with $145 \mu \mathrm{L}(1.20 \mathrm{mmol})$ of cyclohexane carboxaldehyde (n) cooled to $-5{ }^{\circ} \mathrm{C}$ in a cold bath was added $135 \mu \mathrm{L}(1.20 \mathrm{mmol})$ of $o$-anisidine and the solution was OMe allowed to stir at that temperature for $5 \mathrm{~min}$ upon which time it turned cloudy. THF was then added $(1.0 \mathrm{~mL})$ and the solution was allowed to $\mathrm{NH} O \quad$ warm to $22^{\circ} \mathrm{C}$ and ligand $1(30.5 \mathrm{mg}, 60 \mu \mathrm{mol})$ and AgOAc ( $10 \mathrm{mg}$, $60 \mu \mathrm{mol})$ were added and the solution was allowed to stir at that temperature for $5 \mathrm{~min}$. The solution was then cooled to $4{ }^{\circ} \mathrm{C}$ in a cold room and enol ether $\mathbf{3 b}(400 \mu \mathrm{L}, 2.40 \mathrm{mmol})$ was added and the reaction mixture was allowed to stir at $4{ }^{\circ} \mathrm{C}$ for $16 \mathrm{~h}$. The reaction was quenched upon addition of $2 \mathrm{~mL}$ of $10 \%$ aqueous $\mathrm{HCl}$ followed by vigorous stirring for $5 \mathrm{~min} . \mathrm{CH}_{2} \mathrm{Cl}_{2}$ $(5 \mathrm{~mL})$ was added and the mixture was allowed to stir vigorously for $1 \mathrm{~min}$. The layers were allowed to separate, and the bottom layer $\left(\mathrm{CH}_{2} \mathrm{Cl}_{2}\right)$ was removed with a pipette and placed into a round-bottom flask. The aqueous layer was washed with $2 \times 5 \mathrm{~mL}$ portions of $\mathrm{CH}_{2} \mathrm{Cl}_{2}$ and separated as stated above. The combined organic layers were concentrated (without drying) and purified by silica gel chromatography (4:1 hexanes: $\left.\mathrm{Et}_{2} \mathrm{O}\right)$ to deliver $176 \mathrm{mg}(0.64 \mathrm{mmol}, 53 \%)$ of the desired product $\mathbf{4 n}$ as a clear colorless oil. IR (neat, $\mathrm{NaCl}$ ): 3422 (w), 2929 (s), 2855 (m), 1716 (s), 1603 (s), 1518 (s), 1455 (m), 1257 (m), $1217(\mathrm{~m}), 1121(\mathrm{w}), 1030(\mathrm{~m}) .{ }^{1} \mathrm{H}$ NMR $\left(\mathrm{CDCl}_{3}, 400 \mathrm{MHz}\right): \delta 6.84$ (1H, dddd, $J=8.1$, $1.3,0.9,0.5 \mathrm{~Hz}), 6.75(1 \mathrm{H}, \mathrm{dd}, J=7.9,1.5 \mathrm{~Hz}), 6.66-6.60(2 \mathrm{H}, \mathrm{m}), 4.27(1 \mathrm{H}, \mathrm{s}), 3.83$ $(3 \mathrm{H}, \mathrm{s}), 3.78(1 \mathrm{H}, \mathrm{q}, J=6.0 \mathrm{~Hz}), 2.62(2 \mathrm{H}, \mathrm{dddd}, J=16.0,9.2,6.6,5.7 \mathrm{~Hz}), 2.14(3 \mathrm{H}, \mathrm{s})$, 
1.86-1.82 (1H, s), 1.79-1.72 (2H, m), 1.68-1.64 (2H, m), 1.61-1.53 (1H, m), 1.27-1.0 (5H, m). ${ }^{13} \mathrm{C} \mathrm{NMR}\left(\mathrm{CDCl}_{3}, 100 \mathrm{MHz}\right): \delta 208.3,146.9,137.5,121.4,116.1,110.3,109.8,55.6$, 54.0, 46.2, 42.1, 30.7, 29.5, 29.3,26.6, 26.4. HRMS (ES) Calcd for $\mathrm{C}_{17} \mathrm{H}_{25} \mathrm{NO}_{2} \mathrm{Na}$ : 298.1787; Found: 298.1783 . $[\alpha]_{\mathrm{D}}{ }^{20}=+7.1^{\circ}\left(c=2.4, \mathrm{CHCl}_{3}\right)$ for a $94 \%$ ee sample.

The optical purity of $\mathbf{4 n}$ was established by chiral HPLC analysis (OD column, $95 / 5$ hexanes/ $i$-PrOH eluent, $1 \mathrm{~mL} / \mathrm{min}$ and a lamp setting of $254 \mathrm{~nm}$ ); chromatograms are shown below 1
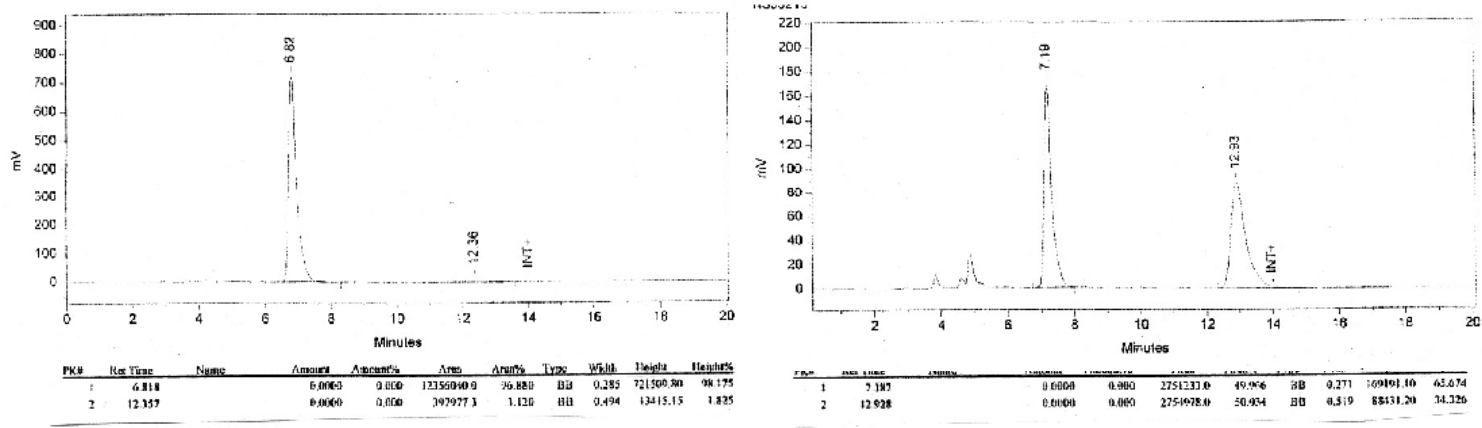

(-)-4-(2-Methoxyphenylamino)-6-methylheptan-2-one (7o); In a 16 x $150 \mathrm{~mm}$ test tube charged with $35 \mu \mathrm{L}(0.40 \mathrm{mmol})$ of isovaleraldehyde (o) cooled to $-5^{\circ} \mathrm{C}$ in a cold OMH O bath was added $45 \mu \mathrm{L}(0.40 \mathrm{mmol})$ of $o$-anisidine and the solution was allowed to stir at that temperature for 5 min upon which time it turned cloudy. THF was then added $(0.5 \mathrm{~mL})$ and the solution was allowed to warm to $22{ }^{\circ} \mathrm{C}$ upon which time ligand $1(10 \mathrm{mg}, 0.02 \mathrm{mmol})$ and AgOAc ( $3.0 \mathrm{mg}, 0.02 \mathrm{mmol}$ ) were added and the solution was allowed to stir at that temperature for $5 \mathrm{~min}$. The solution was then cooled to 4 ${ }^{\circ} \mathrm{C}$ in a cold room and enol ether $\mathbf{3 b}(130 \mu \mathrm{L}, 0.80 \mathrm{mmol})$ was added and the reaction mixture was allowed to stir at $4{ }^{\circ} \mathrm{C}$ for $16 \mathrm{~h}$. The reaction was quenched upon addition of $2 \mathrm{~mL}$ of $10 \%$ aqueous $\mathrm{HCl}$ followed by vigorous stirring for $5 \mathrm{~min}$. $\mathrm{CH}_{2} \mathrm{Cl}_{2}(5 \mathrm{~mL})$ was added and the mixture was allowed to stir vigorously for $1 \mathrm{~min}$. The layers were allowed to separate, and the bottom layer $\left(\mathrm{CH}_{2} \mathrm{Cl}_{2}\right)$ was removed with a pipette and placed into a round-bottom flask. The aqueous layer was washed with 2 × 5 $\mathrm{mL}$ portions of $\mathrm{CH}_{2} \mathrm{Cl}_{2}$ and separated as stated above. The combined organic layers were concentrated (without drying) and purified by silica gel chromatography (4:1 hexanes: $\left.\mathrm{Et}_{2} \mathrm{O}\right)$ to deliver $41 \mathrm{mg}(0.16 \mathrm{mmol}, 41 \%)$ of the desired product 40 as a clear colorless oil. IR (neat, $\mathrm{NaCl}$ ): $3402(\mathrm{w}), 2953$ (m), 1707 (s), 1595 (s), 1514 (s), 1458 (s), $1246(\mathrm{~m}), 1221(\mathrm{~m}), 1028(\mathrm{~m}), 735(\mathrm{~s}) .{ }^{1} \mathrm{H}$ NMR $\left(\mathrm{CDCl}_{3}, 400 \mathrm{MHz}\right): \delta 6.85(1 \mathrm{H}, \mathrm{dt}, J=$ 7.8, $1.4 \mathrm{~Hz}), 6.76(1 \mathrm{H}, \mathrm{dd}, J=7.3,1.1 \mathrm{~Hz}), 6.66-6.62(2 \mathrm{H}, \mathrm{m}), 4.13(1 \mathrm{H}, \mathrm{s}), 3-97-3.90$ $(1 \mathrm{H}, \mathrm{m}), 3.83(3 \mathrm{H}, \mathrm{s}), 2.72(1 \mathrm{H}, \mathrm{dd}, J=16.3,4.7 \mathrm{~Hz}), 2.55(1 \mathrm{H}, \mathrm{dd}, J=16.3,7.1 \mathrm{~Hz})$, $2.13(3 \mathrm{H}, \mathrm{s}), 1.80-1.71(1 \mathrm{H}, \mathrm{m}), 1.54-1.34(2 \mathrm{H}, \mathrm{m}), 0.92(6 \mathrm{H}, \mathrm{dd}, J=11.4,6.8 \mathrm{~Hz}) .{ }^{13} \mathrm{C}$ NMR $\left(\mathrm{CDCl}_{3}, 100 \mathrm{MHz}\right): \delta 208.3,147.0,137.2,121.5,116.4,110.1,109.8,55.6,48.9$, 57.4, 45.0, 31.1, 25.1, 23.3, 22.3. HRMS (ES) Calcd for $\mathrm{C}_{15} \mathrm{H}_{23} \mathrm{NO}_{2} \mathrm{Na}$ : 272.1624; Found: 272.1626. $[\alpha]_{\mathrm{D}}^{20}=-7.0\left(c=1.2, \mathrm{CHCl}_{3}\right)$ for a $94 \%$ ee sample.

The optical purity of $\mathbf{4 o}$ was established by chiral HPLC analysis (OD column, $95 / 5$ hexanes / $i-\mathrm{PrOH}$ eluent, $1 \mathrm{~mL} / \mathrm{min}$ and a lamp setting of $254 \mathrm{~nm}$ ); chromatograms are shown below. 

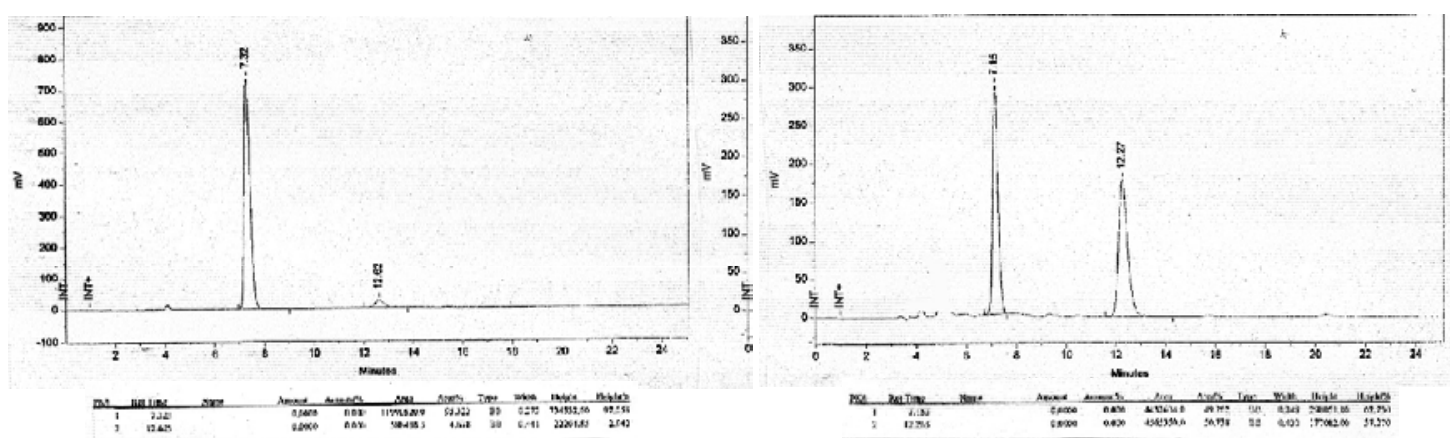

(-)-[1-(4-Chlorophenyl)-3-oxo-3-phenylpropyl]-carbamic acid tert-butyl ester (10);

To a solution of $\mathrm{PhI}(\mathrm{OAc})_{2}(4.20 \mathrm{~g}, 13.1 \mathrm{mmol})$ in $20 \mathrm{~mL}$ of

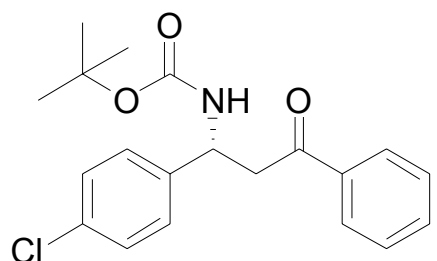
$\mathrm{MeOH}$ and $1 \mathrm{~mL}$ of $\mathrm{AcOH}$ at $22{ }^{\circ} \mathrm{C}$ was added $4 d a(1.2 \mathrm{~g}$, $3.3 \mathrm{mmol}$, in $2.0 \mathrm{~mL} \mathrm{MeOH}$ ) slowly at $22{ }^{\circ} \mathrm{C}$ over $30 \mathrm{~min}$ by a pressure equalizing addition funnel. Upon complete addition the reaction was allowed to stir at $22{ }^{\circ} \mathrm{C}$ for an additional 30 min upon which time $15 \mathrm{~mL}$ of a $10 \%$ aq. $\mathrm{HCl}$ solution (wt \%) was added. The mixture was allowed to stir for 30 minutes at which time $15 \mathrm{~mL}$ of a $10 \%$ aq. $\mathrm{Na}_{2} \mathrm{~S}_{2} \mathrm{O}_{3}$ solution (wt \%) was added and stirring was allowed to continue for an additional $30 \mathrm{~min}$. The solution was made basic by the addition of $\mathrm{Na}_{2} \mathrm{CO}_{3}$ upon which the solution turns dark red, and $\mathrm{Boc}_{2} \mathrm{O}$ was added $(2.90 \mathrm{~g}, 13.1 \mathrm{mmol})$ followed by $5 \mathrm{~mL}$ of $\mathrm{CH}_{2} \mathrm{Cl}_{2}$. The mixture was allowed to stir at $22{ }^{\circ} \mathrm{C}$ for $12 \mathrm{~h}$. The layers were separated and the aqueous layer was washed with $2 \times 50 \mathrm{~mL}$ of $\mathrm{CH}_{2} \mathrm{Cl}_{2}$. The combined organic layers were washed with brine $(1 \times 20 \mathrm{~mL})$, dried over $\mathrm{MgSO}_{4}$ and concentrated. The product was recrystallized from hot hexanes yield $935 \mathrm{mg}(2.60 \mathrm{mmol}, 79 \%)$ of $\mathbf{1 0}$ as a white solid. IR (neat, $\mathrm{NaCl}$ ): 3340 (w), 2356 (m), 1690 (s), 1489 (m), 1440 (w), 1360 (m), 1244 (w), 1165 (m), 1092 (m), 1006 (m), 750 (w). ${ }^{1} \mathrm{H}$ NMR ( $\left.\mathrm{CDCl}_{3}, 400 \mathrm{MHz}\right): \delta$ $8.86(2 \mathrm{H}, \mathrm{d}, J=7.5 \mathrm{~Hz}), 7.53(1 \mathrm{H}, \mathrm{t}, J=7.3 \mathrm{~Hz}), 7.43-7.39(2 \mathrm{H}, \mathrm{m}), 7.28-7.22(4 \mathrm{H}, \mathrm{m})$, $5.66(1 \mathrm{H}, \mathrm{br}), 5.20(1 \mathrm{H}, \mathrm{br}), 3.63-3.60(1 \mathrm{H}, \mathrm{m}), 3.39(1 \mathrm{H}, \mathrm{dd}, J=16.8,5.9 \mathrm{~Hz}), 1.39(9 \mathrm{H}$, s). ${ }^{13} \mathrm{C} \mathrm{NMR}\left(\mathrm{CDCl}_{3}, 100 \mathrm{MHz}\right): \delta 197.9,155.3,140.5,136.7,133.6,133.0,128.8,128.7$, 128.2, 127.9, 79.9, 50.9, 44.0, 28.4. HRMS (ES) Calcd for $\mathrm{C}_{20} \mathrm{H}_{22} \mathrm{NO}_{3} \mathrm{NaCl}$ : 382.1185; Found: 382.1186. Anal Calcd for $\mathrm{C}_{20} \mathrm{H}_{22} \mathrm{ClNO}_{3}$ : C, 66.75, H, 6.16; Found: C, 66.71, H, 6.15. $[\alpha]_{\mathrm{D}}^{20}=-4.8^{\circ}\left(c=1.9, \mathrm{CHCl}_{3}\right)$ for a $>99 \%$ ee sample.

The optical purity of $\mathbf{4 b a}$ was established by chiral HPLC analysis (AD column, 9/1 hexanes/ $i$-PrOH eluent, $1 \mathrm{~mL} / \mathrm{min}$ and a lamp setting of $254 \mathrm{~nm}$ ); chromatograms are shown below. 

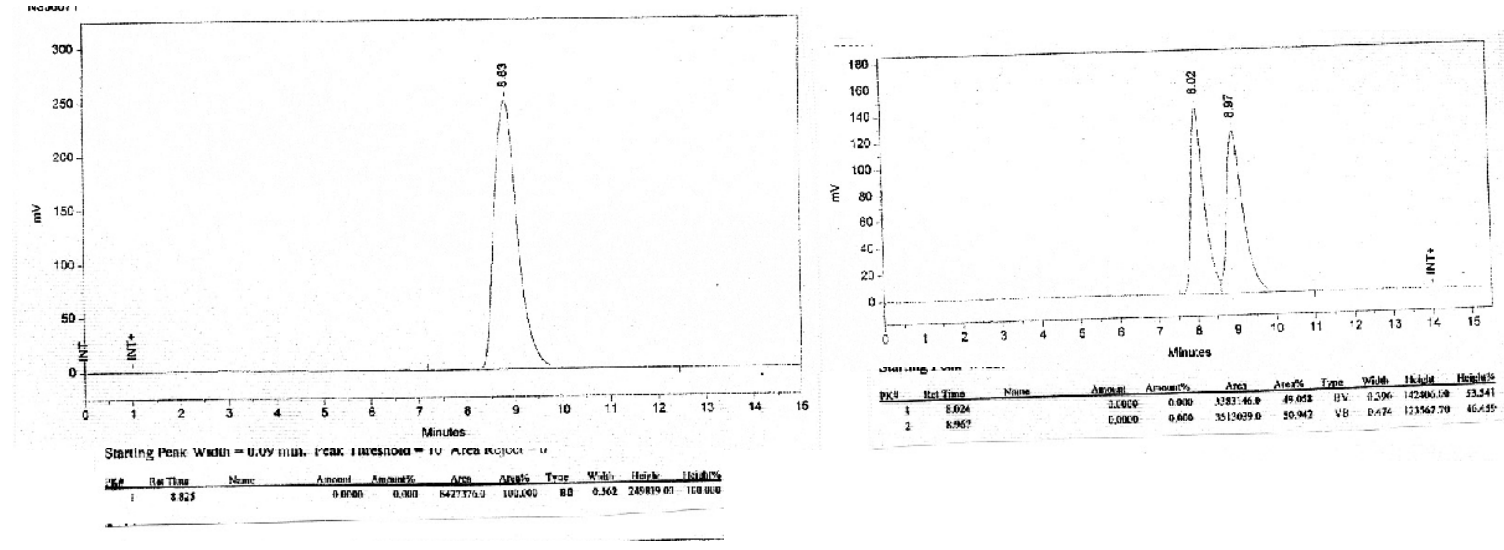

(+)-(3-Oxo-1-phenylethynylbutyl)-carbamic acid tert-butyl ester (11); To a solution of $\mathrm{PhI}(\mathrm{OAc})_{2}(0.55 \mathrm{~g}, 1.7 \mathrm{mmol})$ in $5.0 \mathrm{~mL}$ of $\mathrm{MeOH}$ and $0.10 \mathrm{~mL}$ of $\mathrm{AcOH}$ at $22{ }^{\circ} \mathrm{C}$ was $\mathrm{O}^{\mathrm{O}}$ added $4 \mathrm{lb}(125 \mathrm{mg}, 0.43 \mathrm{mmol}$, in $1.0 \mathrm{~mL} \mathrm{MeOH})$ slowly at $22^{\circ} \mathrm{C}$ O ${ }_{-1} \mathrm{O}$ over $20 \mathrm{~min}$ by pipette. Upon complete addition the reaction was allowed to stir at $22{ }^{\circ} \mathrm{C}$ for an additional 30 min upon which time $5 \mathrm{~mL}$ of a $10 \%$ aq. $\mathrm{HCl}$ solution (wt \%) was added. The mixture was allowed to stir for 30 minutes at which time $5 \mathrm{~mL}$ of a $10 \%$ aq. $\mathrm{Na}_{2} \mathrm{~S}_{2} \mathrm{O}_{3}$ solution (wt \%) was added and stirring was allowed to continue for an additional $30 \mathrm{~min}$. The solution was made basic by the addition of $\mathrm{Na}_{2} \mathrm{CO}_{3}$ upon which the solution turns dark red, and $\mathrm{Boc}_{2} \mathrm{O}$ was added $(370 \mathrm{mg}, 1.7$ mmol) followed by $2 \mathrm{~mL}$ of $\mathrm{CH}_{2} \mathrm{Cl}_{2}$. The reaction was allowed to stir at $22{ }^{\circ} \mathrm{C}$ for $12 \mathrm{~h}$. The layers were separated and the aqueous layer was washed with $2 \times 25 \mathrm{~mL}^{\circ} \mathrm{CH}_{2} \mathrm{Cl}_{2}$. The combined organic layers were washed with brine $(1 \times 10 \mathrm{~mL})$, dried over $\mathrm{MgSO}_{4}$ and concentrated. The product was purified by silica gel chromatography $(3: 2$ hexanes : $\left.\mathrm{Et}_{2} \mathrm{O}\right)$ to yield $85 \mathrm{mg}(0.3 \mathrm{mmol}, 70 \%)$ of $\mathbf{1 1}$ as a yellow orange oil. IR (neat, $\mathrm{NaCl}$ ): 3345 (s), 2974 (m), 1715 (s), 1501 (s), 1369 (s), 1249 (m), 1167 (s), 1048 (m), 765 (m). ${ }^{1} \mathrm{H}$ NMR $\left(\mathrm{CDCl}_{3}, 400 \mathrm{MHz}\right): \delta$ 7.36-7.25 $(5 \mathrm{H}, \mathrm{m}), 5.36(1 \mathrm{H}, \mathrm{br}), 4.95(1 \mathrm{H}, \mathrm{br}), 2.90(2 \mathrm{H}$, ddd, $J=16.8,6.2,4.8 \mathrm{~Hz}), 2.19(3 \mathrm{H}, \mathrm{s}), 1.43(9 \mathrm{H}, \mathrm{s}) .{ }^{13} \mathrm{C} \mathrm{NMR}\left(\mathrm{CDCl}_{3}, 100 \mathrm{MHz}\right): \delta$ 205.8, 154.8, 131.8, 128.5, 128.3, 122.6, 87.6, 83.1, 80.2, 48.7, 39.7, 30.7, 28.4. HRMS (ES) Calcd for $\mathrm{C}_{17} \mathrm{H}_{21} \mathrm{NO}_{3} \mathrm{Na}$ : 310.1423; Found: 310.1419. $[\alpha]_{\mathrm{D}}{ }^{20}=+48.0^{\circ}(c=0.767$, $\mathrm{CHCl}_{3}$ ) for a $88 \%$ ee sample.

(-)-5-(2-Methoxyphenylamino)-7-oxo-7-phenylheptanoic acid methyl ester (8); In a

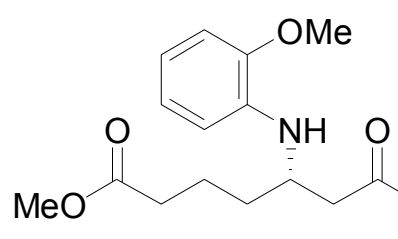

$16 \times 150 \mathrm{~mm}$ test tube charged with $156 \mu \mathrm{L}(1.20 \mathrm{mmol})$ of 5-oxo-pentanoic acid methyl ester ${ }^{5}$ cooled to $-5^{\circ} \mathrm{C}$ in a cold bath was added $135 \mu \mathrm{L}(1.20 \mathrm{mmol})$ of $o$-anisidine and the solution was allowed to stir at this temperature for 5 min upon which time it turned cloudy. THF was added $(1.0 \mathrm{~mL})$ and the solution was allowed to warm to $22{ }^{\circ} \mathrm{C}$ at which time ligand $1(31 \mathrm{mg}, 60 \mu \mathrm{mol})$ and $\mathrm{AgOAc}(10$ $\mathrm{mg}, 60 \mu \mathrm{mol})$ were added and the solution was allowed to stir at this temperature for 5 min. The solution was cooled to $4{ }^{\circ} \mathrm{C}$ in a cold room and enol ether 3a $(0.5 \mathrm{~mL}, 2.4$

\footnotetext{
${ }^{5}$ Huckstep, J.; Taylor, R.J.K. Synthesis 1982, 881-882.
} 
mmol) was added and the mixture was allowed to stir at $4{ }^{\circ} \mathrm{C}$ for $16 \mathrm{~h}$. The reaction was quenched upon addition of $2 \mathrm{~mL}$ of $10 \%$ aqueous $\mathrm{HCl}$ followed by vigorous stirring for 5 min. $\mathrm{CH}_{2} \mathrm{Cl}_{2}(5 \mathrm{~mL})$ was added and the mixture was allowed to stir vigorously for 1 min. The layers were allowed to separate, and the bottom layer $\left(\mathrm{CH}_{2} \mathrm{Cl}_{2}\right)$ was removed with a pipette and placed into a round-bottom flask. The aqueous layer was washed with $2 \times 5 \mathrm{~mL}$ portions of $\mathrm{CH}_{2} \mathrm{Cl}_{2}$ and separated as stated above. The combined organic layers were concentrated (without drying) and purified by silica gel chromatography (4.1 hexanes: $\left.\mathrm{Et}_{2} \mathrm{O}\right)$ to deliver $239 \mathrm{mg}(0.67 \mathrm{mmol}, 56 \%)$ of the desired product 8 as a light yellow oil. IR (neat, $\mathrm{NaCl}$ ): 3408 (w), 2942 (m), 1734 (s), 1683 (s), 1602 (s), 1513 (s), $1451(\mathrm{~m}), 1224$ (s), $1180(\mathrm{~m}), 1029(\mathrm{~m}), 746(\mathrm{~s}) .{ }^{1} \mathrm{H} \mathrm{NMR}\left(\mathrm{CDCl}_{3}, 400 \mathrm{MHz}\right): \delta 7.91$ $(2 \mathrm{H}, \mathrm{d}, J=7.7 \mathrm{~Hz}), 7.55(1 \mathrm{H}, \mathrm{dd}, J=7.5,7.1 \mathrm{~Hz}), 7.44(2 \mathrm{H}, \mathrm{dd}, J=7.9,7.5 \mathrm{~Hz}), 6.84$ $(1 \mathrm{H}, \mathrm{dd}, J=8.0,7.3 \mathrm{~Hz}), 6.76(1 \mathrm{H}, \mathrm{d}, J=8.0 \mathrm{~Hz}), 6.75-6.65(2 \mathrm{H}, \mathrm{m}), 4.30(1 \mathrm{H}, \mathrm{s}), 4.10-$ $4.02(1 \mathrm{H}, \mathrm{m}), 3.83(3 \mathrm{H}, \mathrm{s}), 3.64(3 \mathrm{H}, \mathrm{s}), 3.28(1 \mathrm{H}, \mathrm{dd}, J=16.8,3.7 \mathrm{~Hz}), 3.13(1 \mathrm{H}, \mathrm{dd}, J=$ 16.8, 7.3 Hz), 2.40-2.30 (2H, m), 1.99-1.60 (4H, m). ${ }^{13} \mathrm{C} \mathrm{NMR}\left(\mathrm{CDCl}_{3}, 100 \mathrm{MHz}\right): \delta$ $199.5,173.9$, 133.2, 128.7, 128.1, 121.4, 121.2, 116.6, 115.1, 110.3, 109.8, 55.5, 51.6, 49.2, 43.2, 34.8, 33.9, 21.8. HRMS (ES) Calcd for $\mathrm{C}_{21} \mathrm{H}_{26} \mathrm{NO}_{4}$ : 356.1845; Found: 356.1862. $[\alpha]_{\mathrm{D}}{ }^{20}=-12.6^{\circ}\left(c=1.27, \mathrm{CHCl}_{3}\right)$ for a $>99 \%$ ee sample.

The optical purity of $\mathbf{8}$ was established by chiral HPLC analysis (AD column, 9/1 hexanes/ $i$-PrOH eluent, $1 \mathrm{~mL} / \mathrm{min}$ and a lamp setting of $254 \mathrm{~nm}$ ); chromatograms are shown below.
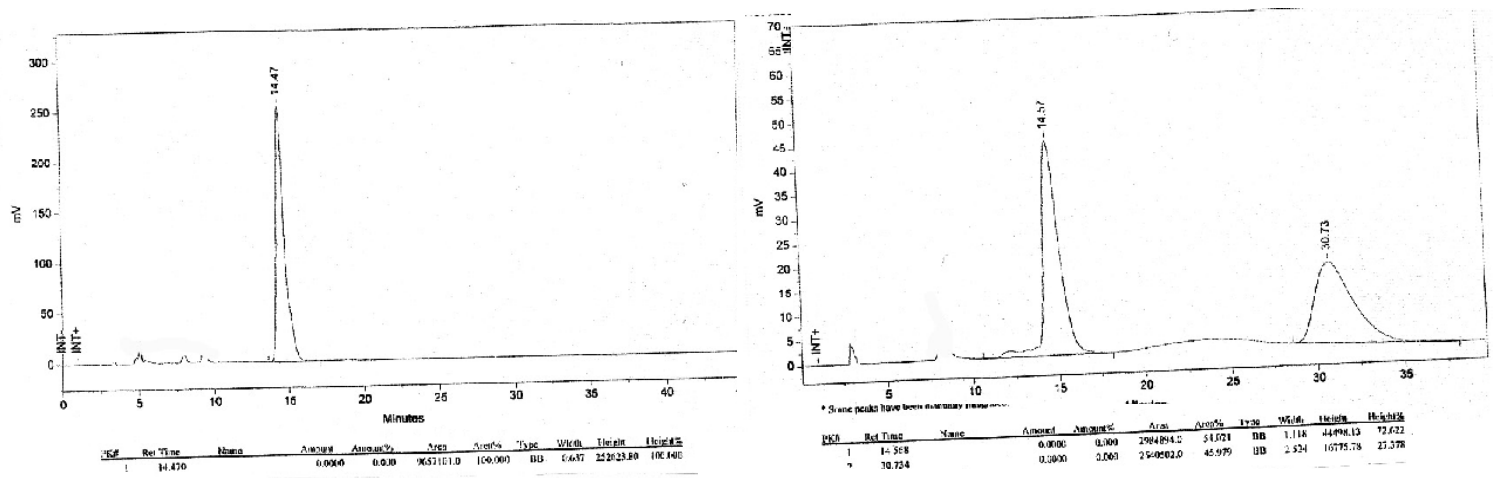

(+)-6-(2-Oxo-2-phenylethyl)-piperidin-2-one (15); To a solution of $\mathrm{PhI}(\mathrm{OAc})_{2}(0.325$, $\mathrm{O} \quad 1.00 \mathrm{mmol}$ ) in $5 \mathrm{~mL}$ of $\mathrm{MeOH}$ and $0.10 \mathrm{~mL}$ of $\mathrm{AcOH}$ at $22^{\circ} \mathrm{C}$ was

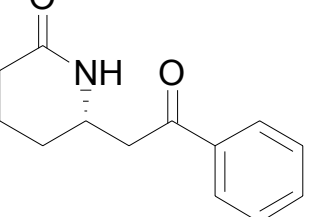
added $14(90 \mathrm{mg}, 0.25 \mathrm{mmol}$, in $1.0 \mathrm{~mL} \mathrm{MeOH})$ slowly at $22{ }^{\circ} \mathrm{C}$ over $20 \mathrm{~min}$ by pipette. Upon complete addition the reaction was allowed to stir at $22{ }^{\circ} \mathrm{C}$ for an additional 30 min upon which time 5 $\mathrm{mL}$ of a $10 \%$ aq. $\mathrm{HCl}$ solution (wt \%) was added. The reaction was allowed to stir for 30 minutes after which time $5 \mathrm{~mL}$ of a $10 \%$ aq. $\mathrm{Na}_{2} \mathrm{~S}_{2} \mathrm{O}_{3}$ solution (wt \%) was added and stirring was continued for an additional 30 min. The solution was then made basic by the addition of $\mathrm{Na}_{2} \mathrm{CO}_{3}$ at which time the solution turns dark red. $\mathrm{CH}_{2} \mathrm{Cl}_{2}$ was added $(2 \mathrm{~mL})$ and the mixture was allowed to stir at $22{ }^{\circ} \mathrm{C}$ for $12 \mathrm{~h}$. The layers were then separated and the aqueous layer was washed with $2 \times 25 \mathrm{~mL}$ of $\mathrm{CH}_{2} \mathrm{Cl}_{2}$. The combined organic layers were washed with brine $(1 \times 10 \mathrm{~mL})$, dried over $\mathrm{MgSO}_{4}$ and concentrated. The product was purified by silica gel chromatography $(4: 1$ EtOAc: $\mathrm{MeOH})$ to yield $44 \mathrm{mg}(0.20 \mathrm{mmol}, 80 \%$ yield) as a white solid. IR (neat, $\mathrm{NaCl})$ : 3254 (w), 1681 (s), 1662 (s), 1600 (s), 1370 (s), 1215 (m), 960 (m), 761 (m), 686 (m). ${ }^{1} \mathrm{H}$ 
NMR $\left(\mathrm{CDCl}_{3}, 400 \mathrm{MHz}\right): \delta 7.92(2 \mathrm{H}, \mathrm{d}, J=7.0 \mathrm{~Hz}), 7.61-7.45(3 \mathrm{H}, \mathrm{m}), 6.42(1 \mathrm{H}, \mathrm{s})$, 4.09-4.03 (1H, m), 3.17 (2H, ddd, $J=17.7,9.1,3.7 \mathrm{~Hz}), 2.45-2.27(2 \mathrm{H}, \mathrm{m}), 2.02-1.97$ $(1 \mathrm{H}, \mathrm{m}), 1.96-1.87(1 \mathrm{H}, \mathrm{m}), 1.84-1.74(1 \mathrm{H}, \mathrm{m}), 1.57-1.48(1 \mathrm{H}, \mathrm{m}) .{ }^{13} \mathrm{C} \mathrm{NMR}\left(\mathrm{CDCl}_{3}\right.$, $100 \mathrm{MHz}): \delta 198.3,171.9,136.5,133.9,128.9,128.1,48.7,45.5,31.7,28.6,19.6$. HRMS (ES) Calcd for $\mathrm{C}_{13} \mathrm{H}_{15} \mathrm{NO}_{2} \mathrm{Na}$ : 240.1006; Found: 240.1000. $[\alpha]_{\mathrm{D}}^{20}=+45.0^{\circ}(c=0.6000$, $\mathrm{CHCl}_{3}$ ).

(-)-Sedamine; In a $100 \mathrm{~mL}$ flask amide $15(250 \mathrm{mg}$, (1.15 mmol) was dissolved in 20 $\mathrm{mL}$ of THF (distilled from Na-benzophenone ketyl) and cooled to $\mathrm{N}^{\mathrm{Me}} \mathrm{OH}$ $-78{ }^{\circ} \mathrm{C}$. A $1 \mathrm{M}$ solution of DIBAL-H in hexanes $(5.75 \mathrm{~mL}, 5.75$ $\mathrm{mmol}$ ) was added slowly to the solution by syringe over $30 \mathrm{~min}$. The solution was allowed to stir at $-78{ }^{\circ} \mathrm{C}$ for an additional 30 min at which time it was warmed to $-40^{\circ} \mathrm{C}$ and $130 \mathrm{mg}(3.4 \mathrm{mmol})$ of $\mathrm{LAH}$ was added directly. The reaction was allowed to stir at $-40{ }^{\circ} \mathrm{C}$ for 30 min then warm to $22^{\circ} \mathrm{C}$ and continued to stir for an additional $1 \mathrm{~h}$. The reaction was then cooled to $0{ }^{\circ} \mathrm{C}$ and a $10 \%$ (aq.) solution (wt \%) of sodium potassium tartrate was added drop wise until the vigorous gas evolution stopped. The solution was allowed to warm to $22{ }^{\circ} \mathrm{C}$ and $15 \mathrm{~mL}$ of $10 \%$ (aq.) solution of sodium potassium tartrate was added and the mixture was allowed to continue stirring for $30 \mathrm{~min}$. The organic layer was separated and the aqueous layer was washed with $3 \times 10 \mathrm{~mL}$ of $\mathrm{CH}_{2} \mathrm{Cl}_{2}$. The combined organic layers were dried over $\mathrm{MgSO}_{4}$ and concentrated to give a light yellow solid. The analysis of the ${ }^{1} \mathrm{H}$ NMR spectrum of this solid shows a 16:1 diastereoselctivity of desired syn reduction to undesired anti reduction.

The resulting solid was then subjected to modified Borch reductive amination conditions ${ }^{6}$. The unpurified product was dissolved in $12 \mathrm{~mL}$ of $\mathrm{CH}_{3} \mathrm{CN}$ at $22{ }^{\circ} \mathrm{C}$ and $\mathrm{NaCNBH}_{3}(360 \mathrm{mg}, 5.75 \mathrm{mmol})$ was added to the solution directly followed by $3 \mathrm{~mL}$ of $37 \%$ formaldehyde (aq.) solution $(0.35 \mathrm{~mol})$ and the reaction was allowed to stir for 5 min. $\mathrm{AcOH}(600 \mu \mathrm{L})$ was added to the solution in 3 parts over $2 \mathrm{~h}$ at 40 min intervals. After each addition of $\mathrm{AcOH}$ the reaction was highly exothermic. The solution was allowed to stir at $22{ }^{\circ} \mathrm{C}$ for $12 \mathrm{~h}$ after which time $5 \mathrm{~mL}$ of $0.1 \mathrm{M} \mathrm{NaOH}$ (aq.) solution was added and the mixture was allowed to continue stirring for $30 \mathrm{~min}$ followed by the addition of $5 \mathrm{~mL}$ of $\mathrm{CH}_{2} \mathrm{Cl}_{2}$. The organic layer was separated and aqueous layer was washed with $3 \times 10 \mathrm{~mL}$ of $\mathrm{CH}_{2} \mathrm{Cl}_{2}$. The combined organic layers were dried over $\mathrm{MgSO}_{4}$ and concentrated. The product was purified by column chromatography on neutral alumina $\left(9: 1 \mathrm{CH}_{2} \mathrm{Cl}_{2}: \mathrm{MeOH}\right)$ to provide $224 \mathrm{mg}(1.0 \mathrm{mmol}, 89 \%$ of $(-)$-sedamine as a white solid. IR (neat, NaCl): 3269 (br), 2936 (s), 2860 (m), 2785 (m), 1740 (m), 1683 (m), 1457 (m), $1375(\mathrm{~m}), 1230(\mathrm{~m}), 1060$ (s), 1029 (s), $758(\mathrm{~m}), 702$ (s). ${ }^{1} \mathrm{H}$ NMR $\left(\mathrm{CDCl}_{3}, 400 \mathrm{MHz}\right): \delta 7.38-7.20(5 \mathrm{H}, \mathrm{m}), 6.22(1 \mathrm{H}, \mathrm{br}), 4.87(1 \mathrm{H}, \mathrm{dd}, J=10.5,2.4 \mathrm{~Hz})$, 3.06-3.02 $(1 \mathrm{H}, \mathrm{m}), 2.85-2.81(1 \mathrm{H}, \mathrm{m}), 2.56-2.51(1 \mathrm{H}, \mathrm{m}), 2.47(3 \mathrm{H}, \mathrm{s}), 2.14-2.06(1 \mathrm{H}, \mathrm{m})$ 1.74-1.71 (1H, m), 1.64-1.54 (2H, m), 1.48-1.44 $(4 \mathrm{H}, \mathrm{m}) .{ }^{13} \mathrm{C} \mathrm{NMR}\left(\mathrm{CDCl}_{3}, 100 \mathrm{MHz}\right)$ : $\delta$ 145.8, 128.3, 127.1, 127.0, 125.7, 125.6, 74.7, 61.0, 51.4, 40.1, 39.9, 25.9, 22.5, 20.7. HRMS (ES) Calcd for $\mathrm{C}_{14} \mathrm{H}_{22} \mathrm{NO}$ : 220.1704; Found: 220.1701. [ $\left.\alpha\right]_{\mathrm{D}}{ }^{20}=-60.8^{\circ}(c=1.21$,

\footnotetext{
${ }^{6}$ Borch, R. F.; Hassid, A. I. J. Org. Chem. 1972, 37, 2321-2323.
} 
EtOH) for a 16:1 diastereomeric mixture. Literature, $[\alpha]_{\mathrm{D}}^{20}=+87.0,(\mathrm{c}=1.10, \mathrm{EtOH})$ for $(+)$-sedamine ${ }^{7}$. M.P. $=59.5-62{ }^{\circ} \mathrm{C}$; literature, $59.0-61{ }^{\circ} \mathrm{C}$.

\footnotetext{
${ }^{7}$ Cossy, J.; Willis, C.; Bellosta, V.; BouzBouz, S. J. Org. Chem. 2002, 67, 1982-1992.
} 